\title{
DESISTINDO DA DENÚNCIA AO AGRESSOR: RELATO DE MULHERES VÍTIMAS DA VIOLÊNCIA DOMÉSTICA
}

\section{LIN CHAU JONG}

Tese apresentada ao Departamento de Saúde Materno-Infantil da Faculdade de Saúde Pública da Universidade de São Paulo para obtenção do título de Doutor em Saúde Pública.

Área de Concentração: Saúde Materno-Infantil

Orientadora: Prof ${ }^{\mathrm{a}} \mathrm{Dr}^{\mathrm{a}}$ Ana Cristina d'Andretta Tanaka Co-orientadora: $\operatorname{Prof}^{\mathrm{a}} \mathrm{Dr}^{\mathrm{a}}$ Maria Lúcia Araújo Sadala

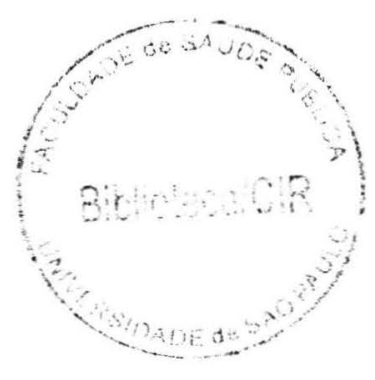

São Paulo

2006 
$47366 / 2006$ doc

Autorizo, exclusivamente para fins acadêmicos e científicos, a reprodução total ou parcial desta tese, por processos fotocopiadores. Ao usa-la, cite a fonte.

Assinatura:

Data 


\section{DEDICATÓRIA}

Este trabalho é dedicado à minha mãe Lin Tsai Yu Wo

(In memorian) 
Agradeço especialmente às mulheres que, generosamente, concordaram em compartilhar a sua experiência, o que tornou possivel a realização deste trabalho 


\section{Agradecimentos}

À Profa. Dra. Ana Cristina d'Andretta Tanaka pela valiosa colaboração e por ter acreditado nos meus objetivos. Pela orientação democrática e consciente, à qual devo a oportunidade de ter concretizado este trabalho.

À Profa. Dra. Maria Lúcia Araujo Sadala pela constante colaboração e sugestões a este trabalho conduzindo-me à pesquisa na perspectiva fenomenológica.

Às Profas. Dras. Ruth Hitomi Osava, Maria Alice Tsunechiro, Wilza Carla Spiri, Maria Luiza Gonzalez Riesco, Isabel Cristina Bonadio e Augusta Thereza de Alvarenga pelo apoio e sugestões na fase de conclusão do trabalho.

À Secretaria de Segurança Pública de São Paulo representada pela Delegacia de Defesa da Mulher de Botucatu pela autorização e apoio à realização desta pesquisa.

À Dra. Simone Alves Firmino Sampaio digníssima delegada da Delegacia de Defesa da Mulher de Botucatu pela oportunidade e contribuição de modo ímpar para a execução e êxito deste trabalho.

Aos srs. Sérgio de Jesus Godinho, Edir Luiz Innocentti, Marcelo Collins da Silva Lino, Alexandre Lunardi digníssimos investigadores de polícia e aos srs. Liliana Therezinha Abílio, Gerlúcia de Oliveira Jesus, Fátima de Lourdes Calore, Marcos Roberto Cação da Cruz, digníssimos escrivães de polícia que contribuíram para execução deste trabalho.

Aos srs. Agnaldo Rodrigues dos Santos e Fernando de Oliveira Alcarde por suas contribuições na digitação da Tese.

Aos funcionários e colegas do Departamento de Enfermagem da Faculdade de Medicina de Botucatu da Universidade Estadual Paulista pela torcida à finalização deste trabalho.

A todos os funcionários do Departamento Saúde Materno-Infantil, pelo carinho, apoio e cumplicidade durante todo o percurso do curso de Doutorado.

Á Pró-Reitoria de Pós-Graduação e Pesquisa da Universidade Estadual Paulista, UNESP, pelo apoio financeiro. 
A blibliotecária Rosemary Cristina da Silva da Biblioteca da Faculdade de Medicina de Botucatu, pela correção das referências bibliográficas.

À sra. Maria de Lourdes da Rosa Pereira pela valiosa contribuição na revisão gramatical.

A todos que direta ou indiretamente contribuíram para o término deste trabalho. 
Jong LC. Desistindo da denúncia: relato de mulheres vítimas de violência doméstica. São Paulo; 2006. [Tese de Doutorado - Faculdade de Saúde Pública - Universidade de São Paulo]

\section{RESUMO}

O estudo tem por objetivo, conhecer e compreender a realidade vivenciada por mulheres vítimas de violência doméstica que se recusaram a dar continuidade ao processo de acusação contra o agressor. Dar seguimento a trabalho anterior sobre o tema, agora na perspectiva das mulheres. Para tanto, foi escolhida a abordagem fenomenológica para conduzir o estudo. Doze mulheres foram entrevistadas, norteadas por uma questão: "Como foi a sua experiência de apresentar queixa contra o seu agressor e, posteriormente, desistir?". As convergências das unidades de significado dos depoimentos foram categorizadas em três temas: 1 . Denúncia e desistência, 2. Relacionamento com as pessoas e 3. Reflexão sobre a experiência vivida. As mulheres expõem sentimentos ambíguos em relação ao agressor: afetividade, raiva, humilhação, medo. Vários fatores levaram-nas a rever a denúncia, que vão do arrependimento e tentativas de conciliação do parceiro, à dependência financeira. Continuar o processo de denúncia surge como situação mais complexa e difícil, em relação à violência vivida. Quando recorrem à justiça, as mulheres esperam repressão do poder público ao comportamento do parceiro, ou sua punição. A desistência pode ser compreendida no contexto da reprodução da estrutura familiar tradicional: a mulher não consegue assumir sua autonomia como pessoa, por esta parecer fora de seu alcance. As noções de justiça e igualdade entre marido e mulher não aparecem claramente nos depoimentos. As mulheres evocam o direito ao respeito como pessoa humana e reconhecem que são dominadas e humilhadas. Estimular essas mulheres a se posicionarem na busca dos seus direitos pode ajudar a atenuar os efeitos perversos do fenômeno da violência doméstica.

\section{Descritores: Violência doméstica; Violência intra-familiar; Violência de gênero; Violência contra a mulher; Fenomenologia.}


Jong LC. Desisting from denunciation: descriptions of women victims of domestic violence. São Paulo; 2006. [Doctoral Thesis - School of Public Health - University of São Paulo]

\begin{abstract}
The study has as its objective to understand and comprehend the reality lived by women who are victims of domestic violence that refuse to give continuity to the process of accusation against the aggressor. It gives follow-up to prior work on this theme, now from the perspective of women. To conduct the present study, a phenomenological approach was chosen. Twelve women were interviewed, guided by one question: "How was your experience of presenting a complaint against your aggressor, and subsequently desisting?" The convergences of signified units from depositions were categorized into three themes: 1 . Denouncing and desisting, 2. Relating to persons and 3. Reflecting on lived experience. The women expressed ambiguous sentiments in relation to the aggressor: affectivity, rage, humiliation, fear. Various factors provoke an examination of denunciation, which range from repentance and attempts at placating the partner, to financial dependence. Continuing the process of denunciation gives rise to a more complex and difficult situation, in relation to lived violence. When the justice system investigates, the women expect repression, from public power to behavior of the partner, or his punishment. Desisting can be comprehended in the context of reproduction of the traditional family structure: the woman does not get to assume her autonomy as a person, for it seems to be beyond her reach. Notions of justice and equality between husband and wife do not appear clearly in depositions. The women evoke their right to respect as human beings and recognize that they are dominated and humiliated. Stimulating these women to position themselves to seek their rights can aid them and attenuate the perverse effects of the phenomenon of domestic violence.
\end{abstract}

\title{
Descriptors: Domestic violence; Intra-family violence; Gender violence; Violence against women; Phenomenology.
}




\section{SUMÁRIO}

1. INTRODUÇÃO

01

1.1Violência doméstica contra a mulher: a inquietação que originou o estudo ...................................................... 01

$1.2 \mathrm{O}$ discurso da literatura sobre o tema ................................................................................................................... 05

2. OBJETIVO

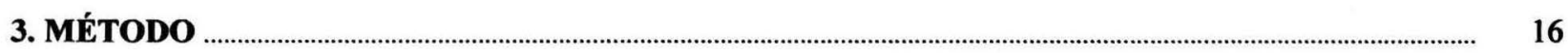

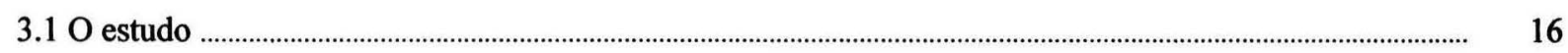

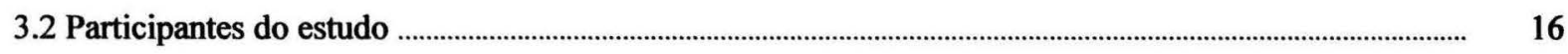

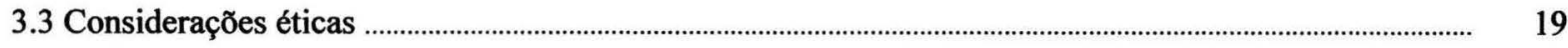

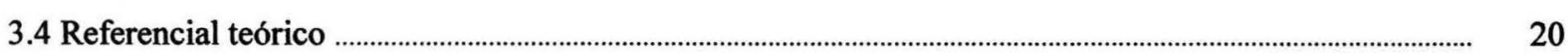

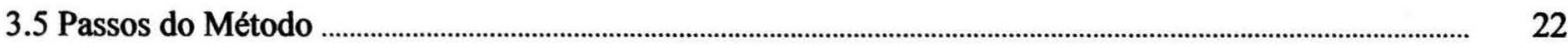

4. RESULTADOS

As descrições das participantes

Análise ideográfica

Analise Nomotética

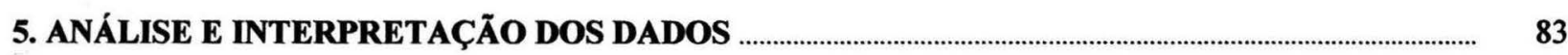

5.1 Denúncia e desistência ............................................................................................................................................ 84

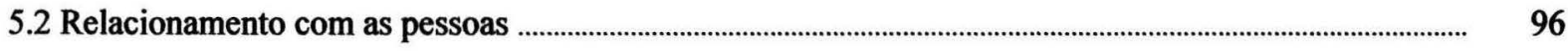

5.3 A Reflexão sobre a experiência de desistir da denúncia ............................................................................... 107

Discussão

6. NOVOS HORIZONTES DESVELADOS, NA PERSPECTIVA DA AUTORA

7. REFERÊNCIAS

\section{ANEXOS}

Anexo 1 - Parecer Favorável do Comitê de Ética em Pesquisa

Anexo 2 - Termo de Consentimento Livre e Esclarecido 


\section{1 - INTRODUÇÃo}

\subsection{Violência doméstica contra a mulher: a inquietação que originou o estudo}

Durante a minha trajetória profissional, desde a formação, tenho me deparado com a violência que atinge a mulher dentro da sua casa, causando prejuízos à sua saúde como um todo e especialmente sobre a sua saúde reprodutiva.

Recém-formada, em meu primeiro emprego como enfermeira obstétrica em maternidade de um hospital na cidade de São Paulo, lembro-me de uma gestante a termo, com feto vivo, ativo e com o batimento cardiofetal dentro da normalidade, durante o meu turno de trabalho de 12 por 36 horas. Considerando o período noturno e a ansiedade manifestada por ela, internei-a no pré-parto, mesmo não estando em trabalho de parto. Assim, ela descansaria e, não havendo progressão do trabalho de parto, o plantão diurno a dispensaria. Deixei o hospital com a paciente dormindo e com o controle do batimento cardiofetal dentro da normalidade. Surpreendi-me quando, no plantão seguinte, 36 horas após, esta gestante retornou à maternidade com sinais de trabalho de parto, e ao examiná-la, não foi possível auscultar batimentos cardiofetais. A ausência destes sinais foi comprovada pelo médico plantonista. A paciente apresentava hematomas no ventre e chorava muito; pareceu conformada quando lhe comunicamos sobre o óbito fetal. Após ter realizado o parto deste natimorto, conversei com a equipe sobre a internação da paciente no plantão anterior e a presença dos hematomas: levantaram-se suspeitas de a paciente ter sofrido agressões durante o intervalo da alta e a posterior re-internação. Foi uma situação que me impressionou. Durante todo o atendimento a esta mulher, evitei tocar no assunto, por não ser habitual na Obstetrícia este tipo de acontecimento. Assim como esta mulher, outras, que viveram situações similares à descrita, vêm à minha memória, nas outras maternidades, onde atuei como enfermeira 
obstétrica, e nos Postos de Saúde do Município de São Paulo, como enfermeira em Saúde Pública.

Desenvolvendo minhas atividades docente-assistenciais em Unidade Básica de Saúde, durante consulta de enfermagem na Prevenção do Câncer Cérvico-Uterino e Detecção Precoce do Câncer de Mama, atendi uma mulher vítima de violência física pelo seu marido. Diante das lesões e traumas visíveis, fui delicadamente oferecer ajuda, dando-lhe oportunidade para expressar suas emoções, ouvindo-a e mostrando-me solidária. Além do apoio emocional, informei-a sobre seus direitos e sobre a existência da Delegacia dos Direitos da Mulher (DDM). Realizei um contato prévio com a enfermeira de uma unidade de saúde, a qual agilizou uma consulta com a psicóloga, para que a mesma pudesse receber este atendimento. Como esse fato aconteceu no período da coleta de dados para a dissertação de mestrado, soube pelos profissionais da polícia civil que a mesma não procurou esta entidade nem a unidade de saúde referida.

Senti-me impotente, lembrando do seu rosto estampado de dor, humilhação e revolta.

Motivada pela vivência dessas situações, desenvolvi, durante o Mestrado, uma pesquisa no município onde atuo, Botucatu (SP) com o objetivo de dimensionar o problema da violência doméstica contra a mulher no espaço que me circunda. Tratou-se de um estudo quantitativo. Os resultados não diferiram de outras pesquisas nessa linha, mostrando mulheres brutalmente atingidas, resignadas a uma posição de cidadãs de segunda categoria (Jong, 2000).

Nos procedimentos de coleta de dados para a pesquisa, consultei os arquivos da DDM da cidade, levantando os boletins de ocorrências (BOs) e termos circunstanciados (TCs) dos anos de 1995 a 1997 - registros de queixas-crime referentes a violências físicas, verbais e sexuais sofridas pelas mulheres deste município. Ao encontrar o carimbo "arquiva-se", em 
vários BOs, era inevitável experimentar uma sensação de mal estar, pois isso indicava que, após a queixa, a própria vítima declarara que voltara a conviver harmoniosamente com o companheiro/agressor. Essas mulheres fazem parte da estatística como vítimas de violência que se caracterizou como doméstica, uma vez que a maioria dos agressores é o marido e/ou companheiro das vítimas.

Durante o levantamento de dados na DDM, o espaço físico que me foi cedido dentro da delegacia para esse fim permitia a escuta involuntária das queixas de mulheres em outras salas, onde eram registrados os $\mathrm{BOs,} \mathrm{bem} \mathrm{como} \mathrm{os} \mathrm{pedidos} \mathrm{de} \mathrm{arquivamento} \mathrm{do}$ processo. Essas escutas involuntárias serviram para a elaboração de questões norteadoras, tanto diante da violência que essas mulheres sofriam quanto diante da resignação e aceitação que elas mostravam ao retirar a queixa contra o agressor.

Durante a pesquisa, tomei conhecimento de várias maneiras que as mulheres que sofreram violência doméstica utilizam para se esquivar da continuidade do processo: quando encaminhadas ao exame de corpo de delito realizado no Instituto Médico Legal (IML), as mulheres denunciantes não compareciam para realizá-lo. Diante disto, não haveria prova prática do crime, portanto, não haveria crime e, não existindo, a norma é arquivar-se. Outra estratégia similar consiste no fornecimento de endereços fictícios para contato posterior, indicando que, tendo decidido pela queixa, durante a efetivação da mesma, a mulher não fornecia os dados corretos, talvez por medo ou insegurança das conseqüências de levar a denúncia adiante. Como, também, não compareciam no prazo de seis meses para manifestar o seu desejo de continuar com o processo contra o agressor. Tudo isto indica a fragilidade da decisão da mulher em exercer o seu direito legítimo de defender-se, resultando no baixo número de inquéritos policiais instaurados. Os resultados da minha pesquisa mostraram que, em média, apenas $8,2 \%$ do total de BOs registrados, no período do estudo, transformaram-se em inquéritos policiais. 
Foi o início de uma inquietação para continuar pesquisando nesta temática. Quanto mais me aprofundava na literatura, mais perplexa ficava com a posição da mulher no mundo. E relembrando a minha própria história, como mulher educada numa cultura patriarcal e oriental, onde a valorização de descendentes do sexo masculino é declarada, para a perpetuação do sobrenome e pelo fato de serem estes os responsáveis pelos pais durante a velhice. Atualmente essa responsabilidade não acontece mais, mas permanece a valorização dos filhos de sexo masculino. Tenho conhecimento de que a preferência por bebês do sexo masculino não é exclusividade da minha cultura, mas me sensibilizo por estar viva enquanto muitas outras meninas chinesas não tiveram o privilégio da vida por causa da diferença territorial e política (política de filho único - controle de natalidade). Penso que, devido à minha experiência particular com a violência e a discriminação da mulher, percebo-me, desde sempre, sensibilizada para as situações da mulher oprimida na sociedade.

Tais inquietações levaram-me a dar continuidade ao estudo deste tema, tentando aprofundar as questões que emergiram na minha pesquisa de Mestrado: o que significa para as mulheres que apresentam queixa contra o seu agressor desistir da denúncia? Propus-me a aproximar-me da sua realidade, na perspectiva delas mesmas, e tentar compreender a sua experiência de renunciar à própria defesa. Muito além de explicações psicológicas ou sócioculturais que condicionam a sua submissão, queria ouvir delas a sua experiência de vivenciar esta realidade.

A seguir, nesta introdução ao estudo, apresento o discurso da literatura, de forma resumida, a respeito da violência contra a mulher, e o referencial teórico do método escolhido para dar voz a essas mulheres. 


\subsection{0 discurso da literatura sobre o tema}

Na seqüência, apresentarei o discurso da literatura a respeito da violência contra a mulher. Ariès (1981) e Badinter (1985) descreveram a condição da família e da mulher na Idade Média e início da Idade Moderna, observando que histórica e culturalmente a violência contra a mulher tem sido algo instituído e aceito como normal, sem maiores questionamentos.

O reconhecimento da violência de gênero no âmbito doméstico tornou-se reconhecida como parte da agenda da Saúde Pública mundial apenas na década de 90, época em que se constatou o papel importante da violência social nas cidades, pelo crescente número de mortes e traumas que provoca na sociedade. A Organização Pan-Americana da Saúde (OPAS), em 1994, priorizou este tema, na elaboração do seu plano de ação regional, instando os governos a executar ações interinstitucionais a fim de prevenir as conseqüências fatais e os agravos à saúde relacionados à violência (Angulo-Tuesta, 1997)

Heise et al. (1994) consideram que a forma mais endêmica de violência contra a mulher é a violência conjugal. Dados do Banco Mundial, apresentados por estas autoras, mostram que a carga da vitimização de gênero para a saúde entre mulheres de 15 a 44 anos iguala-se à representada por outras doenças, como HIV, tuberculose, sepsis durante o parto, câncer e doenças cardiovasculares. A violência doméstica resulta em danos à saúde mental, assinalando-se os seguintes: desordem de estresse pós-traumático, medo, fadiga, depressão, ansiedade, disfunção sexual, desordens da alimentação, desordens múltiplas de personalidade, disfunção do sono. Estas conseqüências também têm sido analisadas por estudiosos do problema, internacionalmente (Plichta et al., 1996; McCauley et al., 1998; Bassuk et al., 2001; Woolhouse et al., 2004).

No Brasil, desde 1940 o Código Penal brasileiro caracterizou a agressão física do marido contra a mulher como delito passível de punição. Na década de 80 do século XX, foi 
criada a Delegacia de Defesa da Mulher, idealizada como espaço legal especializado para receber as denúncias e transmitir segurança e apoio jurídico às mulheres agredidas. Hoje existem instituições destinadas ao amparo de mulheres vítimas de violência, assim como medidas públicas que auxiliam as mesmas.

Para as Nações Unidas, violência contra a mulher é qualquer ato de violência baseado na diferença de gênero, que resulte em sofrimentos e danos físicos, sexuais e psicológicos à mulher; inclusive ameaças de tais atos, coerção e privação de liberdade seja na vida pública ou privada (Senado, 2005). Violência intra-familiar é toda ação ou omissão que prejudique o bem-estar, a integridade física, psicológica ou a liberdade e o direito ao pleno desenvolvimento de um membro da família. Pode ser cometida dentro e fora de casa, por qualquer integrante da família que esteja em relação de poder com a pessoa agredida. Inclui também as pessoas que estão exercendo a função de pai ou mãe, mesmo sem laços de sangue. O termo doméstico incluiria pessoas que convivem no ambiente familiar, como empregados, agregados e visitantes esporádicos (Day et al., 2003).

A violência praticada contra a mulher é um evento inquestionável na realidade mundial. No Brasil, não existe legislação específica que ampare de maneira abrangente o combate à violência praticada contra a mulher inclusive a violência doméstica. Dessa forma, utiliza-se o Código Penal, que é um conjunto de leis que não levou em conta a situação específica da violência contra a mulher. Atualmente, há projetos de lei que trazem algumas alterações progressistas na legislação criminal. Vale a pena citar o Projeto de Lei n. ${ }^{\circ}$ 117/03, da deputada Iara Bernardi, que suprime a expressão "mulher honesta" dos artigos 216 e 231 do Código Penal. No mesmo projeto, a deputada propôs a alteração do artigo 129 do mesmo Código, introduzindo o crime de violência doméstica, é acrescentado os $\S 9^{\circ}$ e $10^{\circ}$ ao artigo 129 com o advento da lei 10886/04.

O legislador prevê a violência doméstica como qualquer lesão corporal provocada 
em ascendente, descendente, irmão, cônjuge ou companheiro ou com quem o agente conviva ou tenha convivido ou, ainda, prevalecendo-se de relações domésticas, de co-habitação ou de hospitalidade. A pena de detenção é de seis meses a um ano*

A violação dos direitos humanos das mulheres, ainda que ocorra no âmbito da família ou da unidade doméstica, diz respeito a toda sociedade, inclusive ao poder público. A violência doméstica não é uma questão de menor importância, ou apenas de ordem privada. A mulher é penalizada em dobro no âmbito das relações domésticas: no reconhecimento e valorização do trabalho doméstico, se torna invisível e desprestigiado e quando se trata da violência ocorrida dentro do mesmo espaço, defende-se a não interferência do setor público em assuntos da esfera privada.

Discussões referentes às relações de gênero, quase que, obrigatoriamente, abordam a violência contra a mulher. $\mathrm{O}$ tema das relações de poder e violência tem a figura caricata do homem das cavernas puxando sua mulher pelos cabelos, revelando assim o domínio através da força. Com o tempo, as relações patriarcais acabaram perpetuando-se através da educação e dos costumes estabelecidos na sociedade. As mulheres são incentivadas desde pequenas a serem inseguras, sensíveis e a cuidar dos outros, internalizando a sua condição de "seres inferiores", menos capazes que os meninos, feitas para viver em função dos homens e para servi-los, em vez de caminhar com eles lado a lado. Já, os meninos são incentivados a não sentirem medo, a não serem frágeis e a exercerem o poder sobre os outros. Desde cedo, meninas e meninos entram no processo de assimilação e adaptação do preconceito, sem se perguntar por que é assim e não de outra maneira.

Em pesquisa telefônica, envolvendo 815 mulheres brasileiras de 27 capitais, identificou uma prevalência de $17 \%$ de violência doméstica contra elas. Destas, 33\% referiram agressão física, com predomínio nas que trabalhavam, e 32\%, de agressões sexuais,

\footnotetext{
"Brasil. Ministério da Justiça. Lei n. 10886/04 de 17 jun 2004. DOU, 2004.
} 
com predomínio nas que não trabalhavam. Os agressores foram, em $65 \%$ dos casos, os maridos e companheiros. Destaca-se que $71 \%$ das agredidas referiram mais de uma agressão, e $50 \%$ referiram quatro agressões e mais. Após a agressão, $22 \%$ foram para a casa da família, $55 \%$ foram à delegacia, e destas, $22 \%$ foram à Delegacia de Defesa da Mulher. Das que foram à delegacia, $70 \%$ delas não tinham para onde ir e voltaram para casa, enfrentando o agressor após denunciá-lo à polícia (Senado, 2005).

Além de influenciar diretamente na auto-estima, a violência doméstica manifestase física e psicologicamente, acarretando em depressão, gastrite nervosa e outros problemas de ordem psicológica e psicossomática. "Em termos globais, as conseqüências do estupro e da violência doméstica para a saúde das mulheres são maiores que as conseqüências de todos os tipos de câncer e pouco menores que os efeitos das doenças cardiovasculares" (Adeodato et al., 2005). Na violência doméstica contra a mulher, o abuso pelo parceiro íntimo é mais comumente parte de um padrão repetitivo, de controle e dominação do que um ato único de agressão física.

O que provoca a violência contra as mulheres? A tendência atual dos pesquisadores é de considerar a interação de diferentes fatores pessoais, situacionais e socioculturais combinando-se para provocar o abuso. Como fatores pessoais do agressor, Day et al. (2003) destacam: ser homem; ter presenciado violência conjugal quando criança; ter sofrido abuso quando criança; pai ausente; consumo de bebidas alcoólicas e/ou drogas. Como fatores de risco da relação: conflito conjugal; controle masculino da riqueza e da tomada de decisões na família. Como fatores da comunidade: pobreza, desemprego; associação a amigos delinqüentes; isolamento das mulheres e famílias. Como fatores da sociedade: normas socioculturais que concedem aos homens o controle sobre o comportamento feminino; aceitação da violência como forma de resolução de conflitos; conceito de masculinidade ligado à dominação, honra ou agressão; papéis rígidos para ambos os sexos. 
A reação da mulher à violência é, freqüentemente, limitada pelas opções à sua disposição. Os motivos mais alegados para continuar em um relacionamento abusivo são: medo de represália, perda do suporte financeiro, preocupação com os filhos, dependência emocional e financeira, perda de suporte da família e dos amigos, esperança de que "ele vai mudar um dia". Apesar das dificuldades, muitas mulheres acabam abandonando os parceiros violentos. As mulheres mais jovens são mais propensas a abandonar estes relacionamentos mais cedo. Situações como aumento do nível da agressão, violência afetando os filhos e apoio sócio-familiar são determinantes na decisão de sair do relacionamento. Mesmo após o término da relação, a violência pode continuar e até aumentar, e o maior risco de ser assassinada pelo marido ocorre após a separação (Day et al., 2003).

O abuso pelo parceiro pode surgir sob várias formas: agressões físicas como golpes, tapas, chutes e surras, tentativas de estrangulamento e queimaduras, quebras de objetos, ameaças de ferir as crianças ou outros membros da família; abuso psicológico; coerção sexual; comportamentos de controle tipo isolamento forçado da mulher em relação à sua família e amigos, vigilância constante de suas ações e restrição de acesso a recursos variados. Kirkwood (1993), uma facilitadora de grupos de apoio à mulheres vítimas de violência doméstica, identificou seis principais componentes da experiência subjetiva das mulheres em relação à violência doméstica. Tais componentes - degradação, medo, objetificação, privação, sobrecarga de responsabilidade e distorção da realidade objetiva - são descritos separadamente, embora na experiência das mulheres abusadas esses se encontrem interligados, no que a autora denominou como uma 'rede de abuso emocional'.

A degradação é a percepção de que, como um ser humano, o indivíduo vale menos ou é menos aceitável do que outros. Constitui uma percepção de que algo essencial sobre si mesmo é sujo. A degradação causa sentimentos de profunda dor e vergonha sobre si mesmo. As mulheres abusadas descrevem uma variedade de degradações verbais, por parte de 
seus parceiros, que incluem: serem chamadas de estúpidas, feias, inadequadas sexualmente e incompetentes. Como formas não-verbais de degradação, as mulheres serem forçadas a atos sexuais indesejados.

O medo é mantido sob duas formas: privação econômica e a social. Na privação econômica, os abusadores assumem o direito de usar ou alocar a renda familiar de acordo com suas próprias necessidades. A privação social refere-se ao controle da oportunidade das mulheres em se engajar em contatos sociais. As mulheres em situação de privação econômica descrevem um sentimento de incerteza sobre o futuro, assim como, uma inabilidade de mudar as circunstâncias de maneira a realizar suas necessidades. Já a privação social tem como impacto um isolamento intenso e sentimentos de solidão.

A objetificação ocorre quando o comportamento dos parceiros indica para a mulher que elas são tratadas como objetos sem nenhum recurso, necessidade ou desejo. Exemplo disso são as demandas dos parceiros para que a mulher altere a aparência para satisfazer suas necessidades e desejos: os parceiros exigem que as mulheres usem um certo tipo ou estilo de roupas que seja adequado à sua idéia de como a mulher deve se apresentar. Há a manipulação dos parceiros quanto ao estado físico delas, forçando-as a fazer uso de medicações ansiolíticas. E, ainda, a possessividade exacerbada dos parceiros: o ciúme, a restrição aos contatos sociais das mulheres e a invasão do espaço da mulher em suas relações sociais sugerem que a mulher é considerada como uma propriedade por seus parceiros.

As mulheres abusadas vivenciam ansiedade a respeito de sua segurança física e emocional, assim como percebem seu corpo e sua identidade sob o risco de danos ou destruição. O rompimento da confiança que ocorre com o primeiro episódio de violência física e a natureza imprevisível de futuros ataques criam uma atmosfera de perigo contínuo e, conseqüentemente, um estado de ansiedade e medo constantes.

A sobrecarga de responsabilidade é vivenciada pelas mulheres como um gasto 
excessivo de energia na manutenção emocional e prática de seus relacionamentos familiares, sem a participação de seus parceiros. As mulheres reportam que seus parceiros não assumem nenhuma responsabilidade no relacionamento conjugal e familiar.

A distorção da realidade objetiva é expressa nas formas pelas quais a confiança na percepção da mulher sobre ela mesma, sobre a dinâmica de seu relacionamento e até mesmo sobre informações factuais acerca de suas experiências são desqualificadas ou negadas por seus parceiros. Por meio da distorção e da descrença em suas próprias percepções, as mulheres sentem-se continuamente vulneráveis em relação aos seus parceiros, o que pode levar ao sentimento de estarem ficando "loucas".

Pesquisa do Centro Brasileiro de Informações sobre Drogas Psicotrópicas da Universidade Federal de São Paulo - Cebrid/Unifesp/EPM - apontou uma prevalência de consumo de álcool em $52 \%$ dos agressores, nos casos de violência doméstica contra a mulher (Muto, 2003). Foram entrevistadas 2.372 pessoas entre 12 e 65 anos, em 27 cidades paulistas com mais de 200 mil habitantes. Cerca de um terço dos lares tinha histórico de violência. Do total de casos com situação de violência doméstica, em $46 \%$ havia relato de consumo de bebidas alcoólicas. Uma pequena porcentagem (6\%) envolvia tanto álcool quanto uso de substâncias psicotrópicas. Violência, consumo de álcool e mulheres extremamente vulneráveis podem desembocar em diferentes desfechos. Para Soares (1996), "definir o agressor como alcoólatra ou embriagado envolve, sem dúvida, uma acusação. Mas a bebida funcionará como agravante em alguns casos e como atenuante em outros, dependendo dos rumos que tomará o "diálogo" - disruptivo ou conciliatório - que a vítima estabelece com o agressor e para o qual convoca a mediação da delegacia. Em qualquer um dos casos, contudo, a presença do álcool não fará mais do que acentuar ou minimizar o teor da violência".

Atualmente podemos observar, de acordo com estudos sobre a temática da violência doméstica (Saffioti, 1994; Schraiber e d'Oliveira, 1999; Silva,1985), que é uma 
violência institucionalizada dentro da família e é no espaço lar que ocorre o maior nível de ocultamento da violência que atinge a mulher, dada toda a ambigüidade da socialização da mulher, que a faz sentir-se culpada e querer justificar a agressão que vivencia (Silva, 1985). Para Azevedo (1986), na medida em que, no contexto social, a condição feminina for de subalternidade no mundo dos homens, a mulher não terá força econômica. Incorporando o mito da superioridade masculina, versus inferioridade feminina, inculcada por uma educação diferenciada e ideologizante, a concepção de que a violência masculina constitui um exercício de natural autoridade, nesse contexto, cabe à mulher aceitar e referendar a sua condição de passividade diante das agressões das quais é vítima.

Nas últimas décadas, a Declaração dos Direitos Humanos para todos, contempla a mulher com programas e eventos na defesa de seus direitos como cidadã (Brasil, 1994). A criação das Delegacias Policiais de Defesa da Mulher institucionalizou o combate à violência contra a mulher. Desde então, passou a haver visibilidade da violência que a vitimiza e também possibilitou a geração de estatísticas que mostram a magnitude do problema, embora de forma subestimada, uma vez que se sabe que os dados visíveis são muito inferiores aos da realidade.

Não obstante o apoio legal que a mulher recebe mediante a atuação das Delegacias da Mulher, algumas pesquisas recentes mostram o quanto a condição histórica e cultural da dependência feminina persiste, dificultando e até impedindo que a mulher rompa as barreiras de sua condição dentro da família.

Silva (2003), entrevistando 701 mulheres em hospital de urgência e emergência em Salvador (BA) constatou que a violência contra a mulher ocorre com mais freqüência no espaço doméstico. Entre as participantes, 321 relataram algum tipo de episódio de agressão: física, sexual e/ou psicológica. As vítimas de agressão física apresentavam número maior de casos de doenças mentais e comportamentais, doenças do aparelho geniturinário e doenças em 
geral.

Resultados de estudo de Kronbauer e Meneghel (2005), desenvolvido em unidade básica de saúde de Porto Alegre (RS), envolvendo 215 mulheres entre 18 e 49 anos, mostraram que $55 \%$ das participantes relataram pelo menos um episódio de violência psicológica por parte do companheiro; $38 \%$ haviam sofrido violência física e $9 \%$, violência sexual. Quanto à condição socio-ecônomica, os níveis de violência entre mulheres que pertenciam às classes menos favorecidas foram muito superiores, quando comparados com os dados referentes às mulheres das classes mais favorecidas.

Adeodato et al. (2005), em estudo envolvendo mulheres, vítimas de agressão pelos parceiros, que apresentaram denúncia contra ele na Delegacia da Mulher do Ceará, concluíram que $72 \%$ das participantes apresentavam quadro sugestivo de depressão clínica; $78 \%$ tinham sintomas de ansiedade e insônia; $38 \%$ haviam pensado em suicídio e $24 \%$ passaram a fazer uso de ansiolíticos após o início das agressões pelo parceiro.

A respeito da sub-notificação da violência doméstica contra a mulher e a desistência em prosseguir na queixa contra o agressor, destaca-se pesquisa desenvolvida por um grupo da Pontifícia Universidade Católica (PUC) de São Paulo, liderado pela professora Heleieth Saffioti, a qual analisa os registros feitos desde 1988 nas Delegacias da Mulher, em São Paulo e em 21 capitais brasileiras (Falcão,1999). Segundo os achados do estudo, 98\% dos agressores não são punidos: as vítimas retiram a acusação, ou os agressores não são encontrados ou são inocentados. O índice de desistência das mulheres, segundo Saffioti, chega a 70\%, devido ao vínculo emocional com o agressor. Mesmo ocorrendo a punição, ao acusado é oferecida uma pena alternativa insignificante, como o pagamento de uma cesta básica. No caso da violência contra a mulher, essa atitude legal mostra-se como uma punição irrisória e sem nenhum valor frente ao crime praticado. Provavelmente, este resultado poderá também desestimular a mulher agredida a empreender uma luta judicial na qual ela se exporá 
a perdas importantes.

Pesquisa do IBGE, desenvolvida em 1998, no Rio de Janeiro, ouviu 57.755 moradores casados de dois bairros de classe média: Maracanã e Tijuca. Entre as mulheres, $12,8 \%$ declararam ter sofrido algum tipo de violência física ou emocional ao longo de 98 , contra $8,5 \%$ dos homens. Os resultados constataram que apenas $6,6 \%$ das mulheres vítimas de violência recorrem às delegacias da mulher, enquanto $3,8 \%$ procuraram delegacias comuns. $21,6 \%$ das mulheres agredidas preferiram relatar a agressão a amigos e parentes. (Falcão, 1999)

Levantamento feito pela Prefeitura de Londrina (PR), avaliando os aos dados da DDM desde agosto de 86 a julho de 98 , mostra que poucas queixas de violência doméstica contra a mulher são levadas até o fim. Entre o total de 19.788 ocorrências registradas, apenas $10 \%$ resultaram em processo judicial. Um dos motivos alegados para a desistência seria a dependência emocional ou financeira dos companheiros. Dados apurados nas delegacias da mulher de São Paulo indicam que $60 \%$ dos casais permanecem juntos depois da queixa. (Falcão, 1999)

$\mathrm{Na}$ minha prática profissional, convivendo com situações de violência que atingem a mulher dentro de sua casa, tenho procurado conhecer essa situação para poder melhor atendê-la e orientá-la. Perguntava-me como é possível a mulher atingida tão brutalmente resignar-se a uma posição de "cidadã de segunda categoria", renunciando aos seus direitos de ser respeitada na própria casa e continuando a conviver com o seu agressor? Como cuidadora dessas mulheres, quando grávidas ou com problemas ginecológicos, é necessário entender o que realmente acontece no processo de prestar queixa na Delegacia de Defesa da Mulher. 


\section{2 - OBJETIVO}

O objetivo desta pesquisa foi conhecer e compreender a realidade da violência doméstica vivenciada pelas mulheres que se recusaram a dar continuidade ao processo de acusação contra o seu agressor. 


\section{3 - MÉTODO}

\subsection{O estudo}

A abordagem fenomenológica foi escolhida como o método mais adequado para conduzir o estudo. Trata-se de uma modalidade de pesquisa qualitativa, que procurou ouvir dos participantes do estudo os relatos da sua experiência, através de entrevistas individuais gravadas, norteadas por uma única questão: "Como foi a sua experiência de apresentar queixa contra o seu agressor e posteriormente desistir?".

O estudo foi desenvolvido no mesmo município de Botucatu, cidade do interior paulista, que foi campo da pesquisa anterior. Utilizaram-se dados e informações da Delegacia Policial da Defesa da Mulher local, para selecionar as participantes da pesquisa.

\subsection{Participantes do estudo}

Doze mulheres que sofreram violência doméstica e registraram boletim de ocorrência (BO) contra o agressor na Delegacia de Defesa da Mulher da cidade de Botucatu- São Paulo- Brasil e, posteriormente, retiraram ou desistiram da queixa, no período de junho de 2004 a julho de 2005.

As entrevistas foram realizadas em dois períodos distintos, de março a junho de 2004 e de março a junho de 2005.

As mulheres incluídas no estudo foram acessadas de três maneiras:

a) seleção das mulheres elegíveis para o estudo a partir da leitura dos registros da DDM, feita pela pesquisadora e, posteriormente, o contato telefônico para convidá-las à participar do estudo, 
b) inclusão das mulheres elegíveis por estarem presentes no Plantão da DDM no momento em que a pesquisadora estava no local e,

c) por encaminhamento pela equipe da DDM, que estava de sobreaviso sobre as finalidades da pesquisa e aceitou colaborar na captação das mulheres.

- As mulheres que haviam desistido do processo contra o companheiro foram convidadas a participar da pesquisa. Foram orientadas sobre as finalidades acadêmicas do estudo, seus objetivos e a utilização dos achados, garantidos o sigilo quantos aos dados e o anonimato das entrevistadas. Também foram orientadas sobre o teor da entrevista.

- As mulheres elegíveis para o estudo foram selecionadas, mas muitas recusaram, sob as mais diversas razões. A natureza do tema justifica a recusa das mulheres em participar da pesquisa. Todas as que aceitaram participar fizeram-no livremente.

O local das entrevistas variou, segundo o desejo da entrevistada: quatro mulheres foram entrevistadas no próprio domicílio e oito, na DDM, em sala reservada, disponibilizada pela direção do serviço para esse fim. A duração média das entrevistas foi de 30 minutos.

A entrevista foi gravada, após prévio consentimento das mulheres. Na pesquisa qualitativa, cujo material de análise é a fala dos sujeitos, é necessário preservar o conteúdo da fala da maneira como foi emitida, sem que se altere ou substitua os termos originais. Com esse cuidado, optou-se pela gravação da entrevista. Há que se estabelecer uma relação empática com os sujeitos da pesquisa, uma vez que as informações dadas podem ser afetadas pela natureza das interações com o entrevistador.

A mulher que era convidada a participar discriminava claramente o papel da autora da pesquisa na instituição, de pesquisadora da Universidade Estadual Paulista de Botucatu, e não como parte do quadro funcional da DDM. 


\section{PARTICIPANTES DO ESTUDO - BOTUCATU, 2004}

\begin{tabular}{|c|c|c|c|c|c|c|c|}
\hline Participante & Idade & Ocupação & Escolaridade & Estado Civil/Tempo & Filhos & $\begin{array}{l}\text { Condição } \\
\text { Pós -Agressão }\end{array}$ & $\begin{array}{l}\text { Agressões } \\
\text { Anteriores }\end{array}$ \\
\hline P1 & 20 & Do lar & $\begin{array}{l}\text { Primário } \\
\text { incompleto }\end{array}$ & Casada 6 anos & 2 & Reconciliação & 1 ocorrência \\
\hline P2 & 26 & Do lar & - & Solteira 1 a $6 \mathrm{~m}$ & s/filhos & Separada & - \\
\hline P3 & 21 & Do lar & $\begin{array}{l}\text { Primário } \\
\text { incompleto }\end{array}$ & Amasiada 5 anos & 2 & Separada & 1 ocorrência \\
\hline P4 & 38 & Do lar & $\begin{array}{l}\text { Primário } \\
\text { incompleto }\end{array}$ & Casada 18 anos & 3 & Reconciliada & 1 ocorrência \\
\hline P5 & 19 & Do lar & $\begin{array}{l}\text { Primário } \\
\text { Incompleto }\end{array}$ & Amasiada 2 anos & s/filhos & Separada & -- \\
\hline P6 & 38 & Doméstica & $\begin{array}{l}\text { Primário } \\
\text { Incompleto }\end{array}$ & Casada 16 anos & 3 & Reconciliada & 1 ocorrência \\
\hline P7 & 22 & Comerciaria & $\begin{array}{l}\text { Primário } \\
\text { Completo }\end{array}$ & Amasiada 4 anos & s/filhos & Reconciliada & 1 ocorrência \\
\hline P8 & 47 & Do lar & - & Casada 18 anos & 1 & Reconciliada & - \\
\hline P9 & 47 & $\begin{array}{l}\text { Aux. } \\
\text { Limpeza }\end{array}$ & $\begin{array}{l}\text { Ensino } \\
\text { Médio } \\
\text { Completo }\end{array}$ & $\begin{array}{l}2^{\circ} \text { casamento } \\
10 \text { anos }\end{array}$ & 1 & Separada & $\begin{array}{l}\text { Ocorrências no casamento } \\
\text { anterior }\end{array}$ \\
\hline P10 & 29 & Comerciária & $\begin{array}{l}\text { Ensino } \\
\text { Médio } \\
\text { Completo }\end{array}$ & Casada 10 anos & 1 & Reconciliada & - \\
\hline P11 & 21 & Lavadeira & $\begin{array}{l}\text { Primário } \\
\text { Completo }\end{array}$ & Amasiada 2 anos & 3 & Reconciliada & - \\
\hline P12 & 39 & $\begin{array}{l}\text { Aux. } \\
\text { Enfermagem }\end{array}$ & $\begin{array}{l}\text { Ensino } \\
\text { Médio } \\
\text { Completo }\end{array}$ & Casada 4 anos & 2 & Separada & - \\
\hline
\end{tabular}

Fonte: Arquivos da Delegacia de Defesa da Mulher (DDM) - Botucatu/SP 


\subsection{Considerações éticas}

O projeto da pesquisa foi, anteriormente ao início da coleta dos dados, submetido ao Comitê de Ética em Pesquisa da Faculdade de Medicina de Botucatu, UNESP, tendo sido aprovado (Anexo I). Foi, também, submetido à apreciação da Delegacia de Defesa da Mulher de Botucatu, na pessoa da delegada responsável, tendo sido autorizadas as entrevistas com as mulheres que desistiram da denúncia do agressor, no período do desenvolvimento do estudo.

As mulheres que haviam desistido do processo contra os companheiros, neste período, foram convidadas a participar da pesquisa. Após concordarem, eram orientadas a respeito da natureza da mesma, seus objetivos e a utilização dos dados obtidos, esclarecendo que seriam garantidos o sigilo quanto aos dados e o anonimato da sua participação. Eram orientadas, também, sobre a forma de entrevista, dirigida por uma questão única, gravada, sendo a fita, posteriormente à transcrição, destruída. Após os esclarecimentos, solicitava-se que assinassem o Termo de Consentimento Esclarecido (Anexo II), após a leitura e a compreensão do mesmo. 


\section{4 - Referencial teórico}

Neste tópico, de forma sucinta, será apresentada a fundamentação teórica que orienta o método escolhido para estudar a desistência das mulheres que apresentam queixa contra o agressor em dar continuidade ao processo legal.

A pesquisa na abordagem fenomenológica busca aproximar-se da experiência vivida, e não encontrar explicações ou conexão causa-efeito, e nem generalizar resultados estatísticos. Propõe-se a compreender os significados que as pessoas que vivenciam o fenômeno em estudo atribuem à sua experiência.

A fenomenologia surgiu com Husserl, como uma alternativa filosófica em contraposição à aplicação dos modelos da Física Clássica para as Ciências Humanas: Husserl criticava a transposição dos métodos sistemáticos das Ciências Naturais, especialmente na Psicologia, sem discernir que os objetos de estudos são diferentes. Esta alternativa, que defende a construção de uma ciência para as experiências vividas, põe em evidência que os seres humanos não são objetos e que suas atitudes não podem ser vistas como simples reações (Martins e Bicudo, 1989).

A fenomenologia é definida por Husserl como "a ciência descritiva das essências da consciência e de seus atos", ou seja, a ciência que descreve o vivido: os atos intencionais de consciência e dos objetos por ela visados. A fenomenologia se volta, portanto, para o estudo da realidade vivida pelos sujeitos na sua vida cotidiana, procurando compreender os significados que estes sujeitos atribuem à experiência vivida.

Ao investigar a experiência das mulheres que desistem da queixa formal contra a violência sofrida dentro de casa, dentre as diversas vertentes da Fenomenologia, foi escolhida para o estudo a Fenomenologia Existencial de Merleau Ponty (1945), autor que segue os passos de Husserl, porém voltando o foco de interesse para o homem inserido no mundo, nas 
suas interações com este mundo, que o determina, mas que, pela sua ação, ele pode transformar. Este autor parece ser o mais adequado para fundamentar e levar às respostas que se procuram: os significados que as mulheres atribuem à experiência vivida.

Martins e Bicudo (1989), baseando-se na filosofia existencial de Merleau Ponty, definem a fenomenologia como aquilo que se manifesta em si mesmo. $O$ ir "às coisas mesmas" para descrevê-las e compreendê-las começa com uma observação empírica - através das falas dos sujeitos que viveram o fenômeno em estudo - nas quais o pesquisador procura chegar às essências do fenômeno contextualizado nos seus elementos históricos; porém, o investigador, desvencilhando-se dos conceitos e preconceitos que ele adquiriu a priori; procura compreender o fenômeno como ele se manifesta na expressão dos próprios sujeitos que o vivenciam.

Nesta abordagem não há "a existência do sujeito e do mundo como sendo puros e independentes um do outro". O conhecimento só será alcançado no próprio existir do pesquisador: o objeto do conhecimento é a realidade vivida pelo pesquisador (Martins e Bicudo, 1989).

Todo estudo da fenomenologia fundamenta-se no conceito de consciência como intencionalidade: a consciência está sempre direcionada para alguma coisa; não há, nesta abordagem, consciência pura, ela sempre estará se direcionando para algo, estabelecendo relação com um objeto, ela sempre será intencionalidade. Todos os atos humanos são, portanto, intencionais e esta intencionalidade é um comportamento dirigido às coisas e pessoas com as quais se relaciona no mundo. A consciência, neste movimento de relacionarse com pessoas e objetos apresenta-se carregada de significados: atribuídora de significados para a experiência que é vivida (Martins, 1992).

Nesta abordagem, portanto, o pesquisador volta a sua intencionalidade para as coisas que se doam à experiência - isto significa que ele olha atentamente para o seu objeto 
de estudo, anda à sua volta. Nisto consiste o olhar fenomenológico.

A fenomenologia procura abordar o fenômeno - aquilo que se manifesta a si mesmo - diretamente, interrogando-o, tentando entendê-lo e captar a sua essência. "Ir às coisas mesmas" (Merleau Ponty, 1945).

Coloca-se, então, a questão: como ir às coisas mesmas?

\subsection{Passos do método}

Inicialmente, a Fenomenologia parte do "dado", que é, segundo Martins e Bicudo (1989), radicalmente empírico: não depende do pressuposto ou conceitos anteriores de uma teoria que o explique.

O primeiro movimento da Fenomenologia é obter a descrição do sujeito que vivencia o fenômeno em estudo. A descrição fenomenológica constitui-se de três elementos (Martins, 1992):

- A percepção - que assume a primazia no processo reflexivo

- A consciência - que se direciona para a experiência vivida como intencionalidade.

- O sujeito - pessoa ou indivíduo que se coloca como ser no mundo vivendo a experiência.

O segundo movimento da trajetória fenomenológica é a redução: neste momento o objetivo é selecionar as partes da descrição do sujeito que são essenciais à compreensão do fenômeno. Procuram-se exatamente as partes de experiência que são verdadeiramente parte da consciência. Através da seleção das partes essenciais do discurso, o pesquisador realiza a redução da descrição do sujeito.

A compreensão fenomenológica, o terceiro movimento da trajetória, envolve a interpretação e a compreensão daquilo que foi expresso no discurso do sujeito. Consiste numa tentativa de especificar os significados daquilo que emergiu como essência na expressão do 
sujeito. A compreensão se torna possível quando o pesquisador, usando o recurso da Fenomenologia, "assume o resultado da redução como um conjunto de asserções significativas para ele, pesquisador, mas que apontam para a experiência do sujeito, isto é, aponta para a consciência que este tem do fenômeno" (Martins,1992). A este conjunto de asserções dá-se o nome de "unidades de significado".

Inicialmente, as unidades são tomadas como são expressas pelo sujeito, exatamente como as suas palavras. A seguir, o pesquisador transforma-as em expressões próprias do seu discurso de pesquisador, tendo o cuidado estrito de manter os seus significados originais. Finalmente, o pesquisador organiza uma síntese das unidades significativas, elaborando a sua interpretação a respeito daquilo que foi expresso pelo sujeito. Esta parte da análise fenomenológica, que consiste na análise individual do discurso de cada sujeito, é chamada de análise ideográfica. Em outro momento, quando o pesquisador procura pelas convergências de todos os discursos obtidos, chega-se à análise nomotética: o momento do individual para o geral, quando se procuram as generalidades sobre o fenômeno estudado, ou seja, as verdades que descrevem a estrutura do fenômeno (Sadala e Adorno, 2002).

De acordo com Martins (1992), considera-se que, quanto maior o número de sujeitos que participam do estudo, maior será a possibilidade de alcançar a essência do fenômeno, embora este não seja o principal critério a ser observado, pois o que se busca são convergências, divergências e idiossincrasia nestas descrições. 


\section{4 - RESULTADOS}

Com a finalidade de explicitar e ilustrar os passos da análise e interpretação dos dados deste estudo, apresentam-se, na seqüência, os momentos da análise dos depoimentos:

- as descrições das participantes do estudo;

- inicialmente, a análise ideográfica de cada depoimento, destacando os passos da redução e análise fenomenológicas, na busca da identificação das unidades de significado e a sua compreensão com enfoque no fenômeno interrogado;

- a seguir, partindo da interpretação das unidades de significado do discurso da participante, com enfoque na questão do estudo, a articulação das idéias expressas por cada uma das participantes, na compreensão da pesquisadora, explicitando os significados essenciais sobre a experiência vivida, que emergiram do seu discurso;

- ao final, a análise nomotética, indicando as convergências das unidades de significado e todos os depoimentos, que desvelam as verdades gerais sobre o fenômeno estudado, segundo as participantes do estudo. 


\section{Depoimento 1}

Uma porque o menino meu, mais velho, tinha ficado com ele, depois ele começou a ir a semana inteira em casa, dizendo que tinha mudado, que não ia acontecer mais, que a situação ia melhorar, entende? Aí foi indo, foi indo, até que me convenceu. Convenceu meu coração a voltar. Ai eu voltei e vi que tava mesmo realmente mudada a situação, que a família dele tinha parado de se meter, entende? Aí, eu peguei e retirei a queixa. Ah! Eu fiquei, desde criança, gosto muito dele, desde criança, sabe? Sou apaixonada, fanática por ele. Aí ficando longe dele, do menino, sofri muito, passei muito sofrimento. Não porque meu pai e minha mãe me maltratava, pelo contrario, me paparicava como se eu fosse, como se eu fosse como um bebezinho. Não queria que eu nem saísse procurar emprego, nada, pois estava me dando, me tratando super bem. Só que a falta do menino e a falta de casa, que na minha casa eu fazia tudo o que eu queria, eu senti assim livre na minha casa, aí eu senti muita falta da minha casa e do meu filho, ai que eu voltei pra trás. Fiquei com minha mãe, com meu pai que aí eu levei só este, que o outro ele não quis entregar, que ele sabia que se entregasse o mais velho eu não voltava mais com ele, apesar de gostar muito dele. Aí, como ele pensou: 'Seguro o menino, daí uns tempos ela volta de novo'. Aí foi que aconteceu. Senti muita raiva quando fiz a queixa, por que a gente é fiel, companheiro, tudo que o companheiro precisa ajuda. De repente, por causa de uma conversa com a mãe dele, ele começou a me agredir, me maltratava, me espancava; uma vez ele falou que ia me matar, tudo, aí eu fiquei muito assustada, muito chocada mesmo. Ai eu vim abrir queixa, pra ver se eu conseguia pegar a guarda do menino, ver se ele me dava sossego. Eu me senti mal pra caramba quando ele me agrediu: uma pessoa que eu confiava, de total confiança, de repente, me agredir sem mais nem menos... Aí (o pai) me chamou pra cuidar da minha mãe, meu pai chegou nele e falou:

'Ó, você deixa a sua esposa lá cuidar da mulher, da mãe dela, tá machucada, não pode se levantar, não pode tomar banho, nada, né, aí ele concordou com tudo numa boa e que podia ir só que daí, chegou ele foi buscar leite na casa da mãe dele, sei lá o que a mãe dele falo pra ele, ele chegou agressivo em casa, falou que não ia ir, por que eu tinha outras irmãs, tinha minhas cunhadas, que podia fazer meu serviço, aí, eu disse, não João, você deu a palavra pro pai, ai ele disse, Ah! Tudo bem então, só que você vai esperar um pouco. Daí ele pegou uma filmadora e começou a gravar dizendo que tava abandonando a casa, que ele tava indo morar com outro homem e começou a falar monte de besteira, de repente, sem mais nem menos, ele começou a me agredir, aí comecei a sofrer muito, foi uma experiência que eu 
espero que ninguém passe pelo o que eu passei. Foi horrível.

Já tinha acontecido outra vez, só que tinha sido diferente, sabe, só que a que mais me machucou foi desta vez, só que dai eu fui morar com a minha mãe, ficar lá com minha mãe e meu pai, aí ele começou a ir lá, casa de minha mãe e de meu pai dizendo que tinha mudado, que tinha se arrependido, que tinha sentido falta de mim, que ele tinha ficado sozinho na casa só ele e o menino pequeno e diz que o menino ficou doente, dizendo que não sabia viver mais sem eu, ai foi indo, foi indo até que convenceu o meu coração, mas aí o meu coração já tava machucado, pedindo pra voltar, mas só que sem ter jeito, eu voltasse, ele ia judiar de mim muito mais, ia dizer: Ó, ela se rebaixou pra mim, ai então me segurei e fiquei lá, fiquei lá, foi indo, foi indo, até que me convenceu a voltar. Agora até que a gente ta vivendo. 
DEPOIMENTO 1

ANÁLISE IDEOGRÁFICA

\begin{tabular}{|c|c|c|c|}
\hline $\begin{array}{l}\text { Unidades de significado } \\
\text { (linguagem do participante) }\end{array}$ & $\begin{array}{l}\text { Primeiras } \\
\text { Elucidações }\end{array}$ & $\begin{array}{l}\text { Linguagem do } \\
\text { Pesquisador }\end{array}$ & $\begin{array}{l}\text { Unidades de Significado } \\
\text { (enfoque no fenômeno interrogado) }\end{array}$ \\
\hline $\begin{array}{l}\text { 1. Uma, porque o menino meu mais velho tinha ficado com } \\
\text { ele... } \\
2 \ldots \text { depois ele começou a ir a semana inteira em casa, } \\
\text { dizendo que tinha mudado, que não ia acontecer mais, que a } \\
\text { situação ia melhorar, entende? Aí foi indo, foi indo, até que } \\
\text { me convenceu, convenceu meu coração a voltar. } \\
\text { 3. Aí eu voltei, e vi que tava mesmo realmente mudada a } \\
\text { situação, que a família dele tinha parado de se meter, } \\
\text { entende? Aí eu peguei e retirei a queixa. } \\
\text { 4. Ah, eu fiquei, desde criança, gosto muito dele, desde } \\
\text { criança, sabe? Sou apaixonada, fanática por ele, aí ficando } \\
\text { longe dele, do menino, sofri muito, passei muito sofrimento. } \\
\text { 5. Não porque meu pai e minha mãe me maltratava, pelo } \\
\text { contrario, me paparicavam como se eu fosse, como se eu } \\
\text { fosse como um bebezinho, não queriam que eu nem saísse } \\
\text { procurar emprego, nada; pois estava me dando, me tratando } \\
\text { super bem. } \\
\text { 6. Só que a falta do menino e a falta de casa, que na minha } \\
\text { casa eu fazia tudo o que eu queria, eu sentia assim livre na } \\
\text { minha casa, aí eu senti muita falta da minha casa e do meu } \\
\text { filho, aí que eu voltei pra trás. } \\
\text { 7. Fiquei com minha mãe com meu pai que aí eu levei só } \\
\text { este, que o outro ele não quis entregar, que ele sabia que se } \\
\text { entregasse o mais velho eu não voltava mais com ele, apesar } \\
\text { de gostar muito dele. Aí como ele pensou 'seguro o menino, } \\
\text { daí uns tempos ela volta de novo', aí foi que aconteceu. } \\
\text { 8. Senti muita raiva quando fiz a queixa, por que a gente é } \\
\text { fiel, companheiro, tudo que o companheiro precisa ajuda. }\end{array}$ & $\begin{array}{l}\text { a semana inteira: } \\
\text { todos os dias da } \\
\text { semana } \\
\text { convencer o coração: } \\
\text { comover, apelar para } \\
\text { os sentimentos. } \\
\text { fanática: } \\
\text { excessivamente } \\
\text { apaixonada }\end{array}$ & $\begin{array}{l}\text { Na separação, o marido ficou } \\
\text { com um filho. } \\
\text { Depois da separação, o marido } \\
\text { prometeu que mudaria seu } \\
\text { comportamento, convencendo-a } \\
\text { a voltar. } \\
\text { Após voltar para casa, } \\
\text { convenceu-se de que a situação } \\
\text { conflituosa resolvera-se e retirou } \\
\text { a queixa. } \\
\text { Ama o marido e sofreu muito, } \\
\text { longe dele e do filho. } \\
\text { Estava bem na casa dos pais, ali } \\
\text { era bem tratada e protegida. }\end{array}$ & $\begin{array}{l}\text { 1.1 Na separação do casal, os filhos } \\
\text { são utilizados para pressionar a } \\
\text { mulher a voltar. } \\
1.2 \text { O arrependimento do marido } \\
\text { convence a mulher a retirar a } \\
\text { queixa. }\end{array}$ \\
\hline
\end{tabular}




\begin{tabular}{|c|c|c|c|}
\hline $\begin{array}{l}\text { Unidades de significado } \\
\text { (linguagem do participante) }\end{array}$ & $\begin{array}{l}\text { Primeiras } \\
\text { Elucidações }\end{array}$ & $\begin{array}{l}\text { Linguagem do } \\
\text { Pesquisador }\end{array}$ & $\begin{array}{l}\text { Unidades de Significado } \\
\text { (enfoque no fenômeno interrogado) }\end{array}$ \\
\hline $\begin{array}{l}\text { 9.De repente por causa de uma conversa com a mãe dele ele } \\
\text { começou a me agredir, me maltratava, me espancava; uma } \\
\text { vez ele falou que ia me matar, tudo, aí eu fiquei muito } \\
\text { assustada, muito chocada mesmo, aí eu vim abrir queixa, pra } \\
\text { ver se eu conseguia pegar a guarda do menino, ver se ele me } \\
\text { dava sossego. Eu me senti mal pra caramba quando ele me } \\
\text { agrediu, uma pessoa que eu confiava, de total confiança, de } \\
\text { repente, me agredir sem mais nem menos... por causa que ela } \\
\text { (a mãe) tinha sofrido um acidente, aí (o pai) me chamou pra } \\
\text { cuidar da minha mãe, meu pai chegou nele e falou: ' Ó, você } \\
\text { deixa a sua esposa lá cuidar da mulher, da mãe dela, tá } \\
\text { machucada, não pode se levantar, não pode tomar banho, } \\
\text { nada' Aí ele concordou com tudo numa boa e que podia ir só } \\
\text { que daí, chegou, ele foi buscar leite na casa da mãe dele, sei } \\
\text { lá o que a mãe dele falou pra ele, ele chegou agressivo em } \\
\text { casa, falou que não eu ia ir, por que eu tinha outras irmãs, } \\
\text { tinha minhas cunhadas, que podia fazer meu serviço, aí, eu } \\
\text { disse, não João, você deu a palavra pro pai, aí ele disse ' Ah! } \\
\text { Tudo bem então, só que você vai esperar um pouco'. Daí ele } \\
\text { pegou uma filmadora e começou a gravar dizendo que eu } \\
\text { tava abandonando a casa, que tava indo morar com outro } \\
\text { homem e começou a falar monte de besteira. De repente, } \\
\text { sem mais nem menos, ele começou a me agredir, aí comecei } \\
\text { a sofrer muito. } \\
10 . \text { Foi uma experiência que eu espero que ninguém passe } \\
\text { pelo o que eu passei. Foi horrível. Já tinha acontecido outra } \\
\text { vez, só que tinha sido diferente, sabe, só que a que mais me } \\
\text { machucou foi desta vez. } \\
\text { 11. Só que daí eu fui morar com a minha mãe, ficar lá com } \\
\text { minha mãe e meu pai, aí ele começou a ir lá, na casa de } \\
\text { minha mãe e de meu pai, dizendo que tinha mudado, que } \\
\text { tinha se arrependido, que tinha sentido falta de mim, que ele }\end{array}$ & $\begin{array}{l}\text { machucar: no texto - } \\
\text { causar sofrimento de } \\
\text { ordem psíquica. }\end{array}$ & $\begin{array}{l}\text { violência do marido. } \\
\text { A violência foi desencadeada } \\
\text { por uma situação envolvendo a } \\
\text { sua família e a do marido, cuja } \\
\text { mãe teria instigado uma crise de } \\
\text { ciúme. }\end{array}$ & $\begin{array}{l}1.1 \text { A agressão do marido contra a } \\
\text { mulher repete-se. } \\
\text { (corresponde à unidade } 1.2 \text { ) }\end{array}$ \\
\hline
\end{tabular}




\begin{tabular}{|l|l|l|}
\hline $\begin{array}{l}\text { Unidades de significado } \\
\text { (linguagem do participante) }\end{array}$ & $\begin{array}{l}\text { Primeiras } \\
\text { Elucidações }\end{array}$ & $\begin{array}{l}\text { Linguagem do } \\
\text { Pesquisador } \\
\text { (enfoque no fenômeno interrogado) }\end{array}$ \\
\hline $\begin{array}{l}\text { tinha ficado sozinho na casa só ele e o menino pequeno e diz } \\
\text { que o menino ficou doente, dizendo que não sabia viver mais } \\
\text { sem eu... Aí foi indo, foi indo até que convenceu o meu } \\
\text { coração, mas aí o meu coração já tava machucado, pedindo } \\
\text { pra voltar... mas só que sem ter jeito, se eu voltasse, se ele ia } \\
\text { judiar de mim muito mais... }\end{array}$ & $\begin{array}{l}\text { mudar. Isto e mais o sofrimento } \\
\text { por estar separada do filho e } \\
\text { longe de casa a fez voltar. } \\
\text { Embora receosa de novas } \\
\text { agressões. }\end{array}$ \\
$\begin{array}{l}\text { 12. Ô, ele se rebaixou pra mim, aí então me segurei e fiquei } \\
\text { lá, fiquei lá, foi indo, foi indo, até que me convenceu a voltar } \\
\text { agora até que a gente tá vivendo. }\end{array}$ & $\begin{array}{l}\text { rebaixar-se: } \\
\text { humilhar-se }\end{array}$ & $\begin{array}{l}\text { O marido humilhou-se diante } \\
\text { dela, ela resistiu, mas acabou } \\
\text { sendo convencida a manter a } \\
\text { união. }\end{array}$ \\
\hline
\end{tabular}




\section{DEPOIMENTO 1}

\section{ARTICULAÇÃO DAS IDÉIAS PELA PESQUISADORA}

Agredida pela segunda vez, a participante deixou o marido e foi viver com os pais após denunciá-lo. Porém ele segurou um filho com ele, o que, segundo ela, influenciou-a a voltar para casa, retirando a denúncia. $\mathrm{O}$ arrependimento do marido e o afeto que lhe tem fizeram-na retomar o casamento; embora reafirme que as marcas deixadas pelas agressões físicas e morais, que causaram-lhe muito sofrimento, principalmente por terem vindo de uma pessoa muito e querida, em quem confiava.

O depoimento expressa os conflitos que vivenciou, a partir do episódio de violência: embora retirando a denúncia e perdoando o agressor, a participante lembra, a todo momento, como os incidentes transformaram o seu relacionamento com o companheiro, atualmente permeado por sentimentos de mágoa e insegurança. 


\section{Depoimento 2}

Olha pra mim, falar de minha situação como é que foi no momento de briga, foi, eu me senti, pois eu sou sozinha em Botucatu, vim de cidade de fora, só tinha ele aqui. Eu me senti no momento humilhada, ele me amarrou e me jogou no quintal de casa, e por fim do jeito que ele me amarrou ali, ele me jogou e chamou os parentes dele daqui; e, como eu não tenho ninguém, quem saiu errada fui eu, porque ele passou para a família dele que eu quis agredir entende, e eu falando que não e eles como são parentes dele sai como errada e ele saiu, limpou a casa, tirou tudo de mim eu só fiquei com o colchão nem o gás ele deixou pra mim e eu liguei pros meus pais primeiro eu vim para a delegacia prestar queixa, outro dia,eu passei pelo IML, constaram manchas no meu corpo porque ele apertava meu pulso fiquei toda machucada dai eu fiquei uma semana, ficando na casa de amigas minhas, batalhando um emprego, estou empregada, mas não quero ficar aqui, to trabalhando no momento, numa escola de informática como vendedora e passei a me alimentar na casa de amigos, porque ele tirou tudo de mim, de casa, e eu liguei lá para a minha familia e expliquei toda a situação e achei que se eu fosse ficar aqui ele iria ficar me atormentando, porque ele voltou lá pra exmulher dele, pra familia dele eu to voltando para minha casa porque este motivo de eu retirar a queixa e não ter mais problemas futuramente. 


\section{DEPOIMENTO 2}

\section{ANÁLISE IDEOGRÁFICA}

\begin{tabular}{|c|c|c|c|}
\hline $\begin{array}{r}\text { Unidac } \\
\text { (linguag }\end{array}$ & $\begin{array}{c}\text { Primeiras } \\
\text { Elucidações }\end{array}$ & & gado) \\
\hline $\begin{array}{l}\text { 1. Eu me senti, pois eu sou sozinha em Botucatu, vim } \\
\text { de cidade de fora, só tinha ele aqui, eu me senti, no } \\
\text { momento, humilhada. } \\
\text { 2. Ele me amarrou e me jogou no quintal de casa e, por } \\
\text { fim, do jeito que ele me amarrou ali, ele me jogou e } \\
\text { chamou os parentes dele daqui... } \\
\text { 3... como eu não tenho ninguém, quem saiu errada fui } \\
\text { eu, porque ele passou para a família dele que eu quis } \\
\text { agredir, entende? e eu falando que não e eles, como são } \\
\text { parentes dele... saí como errada e ele saiu, limpou a } \\
\text { casa, tirou tudo de mim, eu só fiquei com o colchão, } \\
\text { nem o gás ele deixou pra mim... } \\
\text { 4.... e eu liguei pros meus pais primeiro, eu vim para a } \\
\text { delegacia prestar queixa. } \\
\text { 5. Outro dia, eu passei pelo IML, constaram manchas } \\
\text { no meu corpo, porque ele apertava meu pulso, fiquei } \\
\text { toda machucada. } \\
\text { 6. Daí eu fiquei uma semana ficando na casa de amigas } \\
\text { minhas, batalhando um emprego. } \\
\text { 7. Estou empregada, mas não quero ficar aqui, tô } \\
\text { trabalhando no momento, numa escola de informática, } \\
\text { como vendedora, e passei a me alimentar na casa de } \\
\text { amigos, porque ele tirou tudo de mim, de casa... } \\
\text { 8. Eu liguei lá para a minha família e expliquei toda a } \\
\text { situação e achei que, se eu fosse ficar aqui, ele iria ficar } \\
\text { me atormentando, porque ele voltou lá pra ex-mulher } \\
\text { dele, pra família dele. } \\
\text { 9. Eu tô voltando para minha casa, este é motivo de eu } \\
\text { retirar a queixa e não ter mais problemas futuramente. }\end{array}$ & $\begin{array}{l}\text { errada: pecaminosa, } \\
\text { imoral; que se comporta } \\
\text { mal. } \\
\text { limpar a casa: esvaziar } \\
\text { a casa. } \\
\text { primeiro: que é o mais } \\
\text { importante } \\
\text { IML: Instituto Médico } \\
\text { Legal } \\
\text { nanchas:sinais, marcas. } \\
\text { batalhar: esforçar-se } \\
\end{array}$ & $\begin{array}{l}\text { A agressão pelo marido abateu-a } \\
\text { e envergonhou-a, agravada pelo } \\
\text { fato de contar apenas com ele } \\
\text { nesta cidade. } \\
\text { Sofreu agressão física e moral, } \\
\text { diante dos parentes do marido. } \\
\text { Sozinha, foi exposta à família do } \\
\text { marido como culpada e teve ao } \\
\text { pertences retirados da sua casa. } \\
\text { Preocupou-se em avisar } \\
\text { imediatamente os pais sobre a } \\
\text { agressão. } \\
\text { Foi ao IML para exame das } \\
\text { marcas da agressão. } \\
\text { Durante uma semana ficou na } \\
\text { casa de amigas e esforçou-se por } \\
\text { conseguir emprego. } \\
\text { Está trabalhando e está em casa } \\
\text { de amigas, mas não deseja } \\
\text { continuar nesta cidade. } \\
\text { Receia ser importunada pelo } \\
\text { agressor se continuar na mesma } \\
\text { cidade. } \\
\text { A retirada da queixa se deve ao } \\
\text { fato de deixar a cidade e evitar } \\
\text { problemas futuros. }\end{array}$ & $\begin{array}{l}\text { 2.1 A agressão pelo marido, pessoa em quem se } \\
\text { confia, provoca abatimento e vergonha. } \\
2.2 \mathrm{Na} \text { violência doméstica, à agressão física } \\
\text { associa-se agressão moral. } \\
2.3 \text { A exposição da agressão à família do } \\
\text { marido significa um julgamento de } \\
\text { culpabilidade. } \\
2.4 \text { Os pais significam segurança no momento } \\
\text { da agressão. } \\
\text { 2.5 Após a queixa formalizada, a mulher } \\
\text { agredida fisicamente é submetida a exame no } \\
\text { IML } \\
2.5 \text { As amigas apóiam após a agressão. } \\
\text { 2.6 Mesmo separando-se do agressor, a mulher } \\
\text { teme ser importunada novamente. }\end{array}$ \\
\hline
\end{tabular}




\section{DEPOIMENTO 2}

\section{ARTICULAÇÃO DAS IDÉIAS PELA PESQUISADORA}

A participante descreve um quadro de agressão física e moral, no qual foi humilhada, expulsa e despojada da sua casa, sem apoio de familiares. Apesar da violência e da humilhação às quais foi submetida, optou por retirar a denúncia e abandonar a cidade, para se livrar de qualquer ligação com o agressor, que voltou para a ex-mulher. Aparentemente, ela expressa medo de possíveis agressões futuras provocadas pela denúncia. E também deseja esquecer o quadro de dor e humilhação. 


\section{Depoimento 3}

Como foi pra mim. Foi sei lá. Na hora senti raiva, ódio, pois nem meu pai nunca pois a mão em mim e é muito duro a pessoa apanhar na cara e falar que ama, pois se o marido gostasse, eu acho que ele jamais bateria na mulher se ele tivesse amor próprio, até porque sei lá, eu nunca dei motivo pra ele me bater, a casa sempre tava limpa.

Ele achava que porque vinha drogado, tinha que bater em mim.Eu não aceitei, vim aqui dar queixa, no dia só deram queixa, da primeira vez que eu vim não deu nada, continuei com ele, não chamaram.

A própria escrivã, que atende a gente ali, falou que não ia dar em nada, que isso era só um susto, uma queixa, que eles não podiam fazer nada. Aí, daquela hora eu pensei que não adianta nem fazer exame de corpo delito, vim as outras duas vezes que me chamaram, mas depois na terceira eu não vim, ela me ligou, eu falei que não viria, porque a justiça não adianta da nada no Brasil. A justiça de hoje o homem bate, vem ele dão um conversadinha, amanha o homem bate de novo e continua sempre assim e a mulher vai... pra que isso? Eu acho também, não tenho nada contra nem com a vida de ninguém, se a mulher nem resolve tem que continuar com o marido depois de apanhar é porque ela gosta, e dai eu acho que nem a justiça tem que entrar mais no meio.

Eu acho que teria que ter vergonha na cara e jamais voltas duas e três vezes dar queixa. Porque se ele ta morando ainda com o homem é porque ela aceitou. Ta certo, tem muita gente que não tem custo de vida, não tem como sobreviver, depende do marido, mas eu não tenho estudo, não tenho uma profissão eu não tenho nada, dependo dos meus pais, minha mãe ta desempregada e meu pai é autônomo eu vivo com as minhas duas filhas, mal ou bem eu to comendo, ma também não to apanhando, to tendo uma vida melhor, não adiantava na minha casa eu tinha tudo o que eu queria, mas não tinha sossego, a qualquer momento eu podia ta dormindo, tinha que dormir com o olho aberto, e outro fechado, porque ele podia chegar drogado e me bater, pra que essa vida? Sabe, eu morei com ele durante cinco anos, durante três anos ele foi bom dois anos ele começou, não me batia mas me falava coisas horríveis, ofendendo, saia de casa e voltava três ou quatro dias depois. Da segunda vez eu não aceitei, e eu acho que a mulher tem que erguer a cabeça porque se o homem pode viver sem a mulher, a mulher, também, pode viver sem o homem. Ele depende da mulher pra tudo, então eu acho, sei lá, tem muita mulher que falta vergonha na cara e a justiça também tem que ser mais rígida com o homem. É muita coisa que tem que ser acertada. 


\section{DEPOIMENTO 3 \\ ANÁLISE IDEOGRÁFICA}

\begin{tabular}{|c|c|c|c|}
\hline $\begin{array}{l}\text { Unidades de significado } \\
\text { (linguagem do participante) }\end{array}$ & Primeiras Elucidações & Linguagem do Pesquisador & $\begin{array}{c}\text { Unidades de Significado } \\
\text { (enfoque no fenômeno interrogado) }\end{array}$ \\
\hline 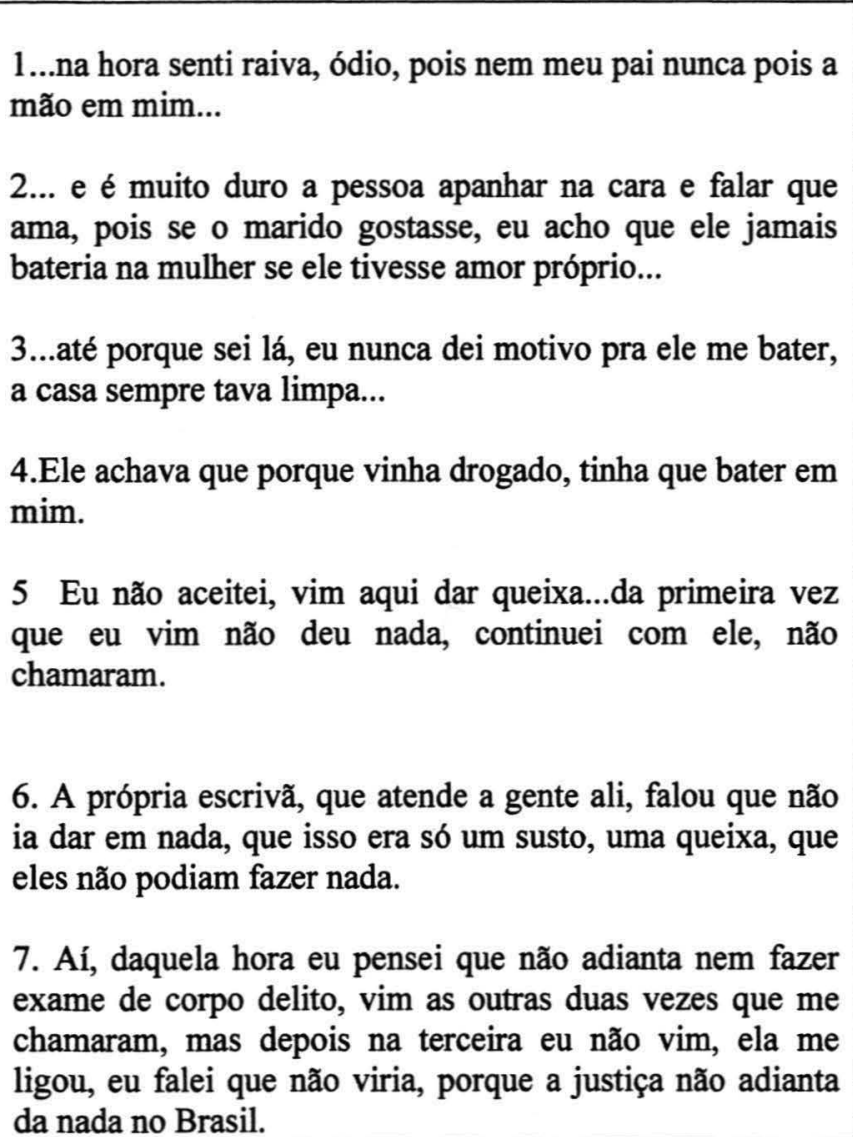 & $\begin{array}{l}\text { Não deu nada: a delegacia } \\
\text { ignorou a denúncia } \\
\text { Susto: sobressalto, espanto } \\
\text { Corpo de delito: exame dos } \\
\text { sinais da agressão sofrida. }\end{array}$ & $\begin{array}{l}\text { Qualquer toque agressivo provoca } \\
\text { aversão. } \\
\text { Agredir a quem se ama mostra } \\
\text { falta de auto-estima. } \\
\text { Haveria motivo para a agressão se } \\
\text { a mulher não cumprisse seu papel } \\
\text { em casa. } \\
\text { Justificar-se-ia a agressão pelo uso } \\
\text { de drogas. } \\
\text { Na primeira queixa, a delegacia } \\
\text { ignorou a denúncia. } \\
\text { A escrivã informou a vítima que o } \\
\text { objetivo da denúncia seria deixar o } \\
\text { agressor de sobre-aviso, porém não } \\
\text { haveria punição para o agressor.. } \\
\text { A experiência de retornar } \\
\text { inutilmente à delegacia a fez } \\
\text { desistir da denúncia. }\end{array}$ & $\begin{array}{l}\text { 3.1 Qualquer toque agressivo é inaceitável. } \\
\text { 3.2 Agressão física à companheira é } \\
\text { incompatível com amor e respeito próprio. } \\
\text { 3.3 Agredir é justificável se a mulher não } \\
\text { cumpre sua função doméstica. } \\
\text { 3.4 O agressor alega o uso de droga como } \\
\text { motivo da agressão. }\end{array}$ \\
\hline
\end{tabular}




\begin{tabular}{|c|c|c|c|}
\hline $\begin{array}{l}\text { Unidades de significado } \\
\text { (linguagem do participante) }\end{array}$ & Primeiras Elucidações & Linguagem do Pesquisador & $\begin{array}{c}\text { Unidades de Significado } \\
\text { (enfoque no fenômeno interrogado) }\end{array}$ \\
\hline $\begin{array}{l}\text { 8. A justiça de hoje o homem bate, vem ele dão um } \\
\text { conversadinha, amanhã o homem bate de novo e continua } \\
\text { sempre assim e a mulher vai... pra que } \\
\text { isso? } \\
\text { 9....se a mulher nem resolve tem que continuar com o } \\
\text { marido depois de apanhar é porque ela gosta, e daí eu acho } \\
\text { que nem a justiça tem que entrar mais no meio. } \\
\text { 10...teria que ter vergonha na cara e jamais voltar duas e } \\
\text { três vezes dar queixa. Porque se ela tá morando ainda com } \\
\text { o homem é porque ela aceitou. } \\
\text { 11.Tá certo, tem muita gente que não tem custo de vida, } \\
\text { não tem como sobreviver, depende do marido... } \\
\text { 12... mas eu não tenho estudo, não tenho uma profissão eu } \\
\text { não tenho nada, dependo dos meus pais...eu vivo com as } \\
\text { minhas duas filhas, mal ou bem eu tô comendo, mas } \\
\text { também não tô apanhando, tô tendo uma vida melhor... } \\
\text { 13... na minha casa eu tinha tudo o que eu queria, mas não } \\
\text { tinha sossego...tinha que dormir com o olho aberto, e outro } \\
\text { fechado, porque ele podia chegar drogado e me bater, pra } \\
\text { que essa vida? } \\
\text { 14. Sabe, eu morei com ele durante cinco anos, durante } \\
\text { três anos ele foi bom, dois anos ele começou, não me batia } \\
\text { mas me falava coisas horríveis, ofendendo, saia de casa e } \\
\text { voltava três ou quatro dias depois, da segunda vez eu não } \\
\text { aceitei... }\end{array}$ & $\begin{array}{l}\text { Falava coisas horríveis: a } \\
\text { agressão verbal é considerada } \\
\text { uma forma de violência } \\
\text { psicológica. } \\
\begin{array}{l}\text { Erguer a cabeça: estar } \\
\text { consciente da sua dignidade, }\end{array}\end{array}$ & $\begin{array}{l}\text { Na delegacia apenas conversam } \\
\text { com o agressor, sem resultados } \\
\text { práticos. } \\
\text { A mulher que continua com o } \\
\text { marido após ser agredida faz sua } \\
\text { opção. } \\
\text { Ser agredida várias vezes e } \\
\text { continuar com o marido significa } \\
\text { concordar. } \\
\text { A dependência do marido pode } \\
\text { explicar a aceitação dos seus atos } \\
\text { violentos. } \\
\text { A falta de trabalho leva a depender } \\
\text { dos pais, mas livra-a da violência } \\
\text { doméstica. } \\
\text { O conforto material não compensa } \\
\text { a ameaça constante de agressão. }\end{array}$ & $\begin{array}{l}\text { 3.8 A mulher que aceita a agressão escolhe ser } \\
\text { vítima. } \\
\text { 3.9 A repetição da agressão significa a } \\
\text { aceitação da violência. } \\
\text { 3.10 A dependência financeira da mulher } \\
\text { submete-a à violência doméstica. } \\
\text { 3.10 A ausência de uma profissão submete a } \\
\text { mulher à dependência dos familiares. } \\
\text { 3.11 A possibilidade de agressão gera ansiedade } \\
\text { constante. }\end{array}$ \\
\hline
\end{tabular}




\begin{tabular}{|c|c|c|c|}
\hline $\begin{array}{l}\text { Unidades de significado } \\
\text { (linguagem do participante) }\end{array}$ & Primeiras Elucidações & Linguagem do Pesquisador & $\begin{array}{l}\text { Unidades de Significado } \\
\text { (enfoque no fenômeno interrogado) }\end{array}$ \\
\hline $\begin{array}{l}15 \ldots \text { a mulher tem que erguer a cabeça porque se o homem } \\
\text { pode viver sem a mulher, a mulher também pode viver sem } \\
\text { o homem. Ele depende da mulher pra tudo...tem muita } \\
\text { mulher que falta vergonha na cara... } \\
16 \ldots \text { e a justiça também tem que ser mais rígida com o } \\
\text { homem. É muita coisa que tem que ser acertada. }\end{array}$ & $\begin{array}{l}\text { sem nada de que se } \\
\text { envergonhar. } \\
\text { Rígida: rigorosa, austera, } \\
\text { severa. } \\
\text { Homem: no contexto, o } \\
\text { agressor. }\end{array}$ & $\begin{array}{l}\text { da sua dignidade. } \\
\text { A justiça precisa ser mais severa } \\
\text { com o agressor. }\end{array}$ & $\begin{array}{l}\text { 3.13 A mulher deve ter dignidade e reafirmar } \\
\text { sua autonomia. } \\
\text { 3.14 A lei deve ser severa para os agressores. }\end{array}$ \\
\hline
\end{tabular}




\section{DEPOIMENTO 3}

\section{ARTICULAÇÃo DAS IDÉIAS PELA PESQUISADORA}

A participante, após sofrer a segunda agressão, denunciou o agressor e o deixou. Considera que a mulher deve ter dignidade e ter autonomia para deixar um companheiro que a maltrata. Mesmo sem independência financeira, como ela, que voltou a viver com os pais. Seu depoimento apresenta contradições: defende a dignidade da mulher em defender-se da agressão, que, aparentemente, só é exercida após a repetição do ato violento. Talvez na primeira agressão a mulher deva ser compreensiva? Atribui a agressividade do companheiro contra ela ao uso de drogas. Não aceita que o homem que diz amá-la a agrida fisicamente. Defende os direitos de igualdade da mulher e desqualifica a atuação da lei, desacreditando do poder da delegacia da mulher em apoiar a defesa das vítimas como ela. Por este motivo, recusou-se a voltar à delegacia após a denúncia, desistindo de continuar o processo legal. 


\section{Depoimento 4}

É uma situação dificil, humilhante, constrangedora, e a gente se sente muito mal e posso falar mais, desesperadora que leva a fazer isto, entendeu, no momento de nervoso de dor, de humilhação de raiva, de um monte de coisa a gente é levada a fazer isto daí, prestar queixa, ir na delegacia prestar queixa é isto daí.

$E$, por que no meu caso, no meu caso que aconteceu isso, meu marido bebe, a defeito dele é a bebida. Ele é uma pessoa trabalhadora, não tem vícios, fora a bebida, ele não, não tem assim, envolvimento com outros casos, de assim mulheres, não tem amantes, nos não temos problemas com traição, não é o nosso caso e ele é uma pessoa que bebe, ele fica muito valente quando bebe, ele se transforma, fica com um comportamento agressivo, então é onde a gente não pode falar nada, as vezes eu respondo ele, é aonde ele parte pra ignorância, que ele parte, assim pra agressão, fala assim coisas que a gente não deve, entende? Que nem comigo já aconteceu duas vezes eu precisava procurar a policia porque ele tava tão bêbado, tão bêbado, que ele tava assim violento demais e meu medo, sei lá, que ele pegasse alguma faca, porque arma em casa a gente não tem, foi ai que eu fiz a denuncia.

E também, quando a gente vai fazer a denuncia é uma situação muito humilhante, que nem pra mim que sou mulher que sempre trabalhou fora e casa com baixaria, minha familia não teve essas coisas, ai a gente vai na hora do desespero mesmo e se sente muito humilhada, de saber que a gente ta lá na delegacia e que ta sendo obrigada a fazer isso, pra ver se a pessoa toma consciência, toma vergonha na cara, para com essa bebida, ele já fez isso duas vezes, a primeira eu levei o caso até o juiz, foi processado, o juiz falou que se ele fizesse isso de novo ele seria preso, por causa de agredir.

A segunda achei que deveria retirar, dar mais uma chance pra ele, eu achei que foi assim, uma coisa impensada e porque envolve filhos, 18 anos, envolve um monte de coisas, bens que a gente tem, e no caso a gente ia ter que vender tudo, e eu não tava em condições de tomar partido pra fazer uma divisão de bens, eu doente, me encontrava em tratamento e não tinha pra onde ir, dispor da casa, é uma situação muito complicada, os filhos menores, então eu achei que desta vez passa, porque depois que passa a bebida ele é outra pessoa, eu já falei que ele é uma pessoa muito responsável, o patrão dele adora ele, trabalha firme há 23 anos. Só numa firma, como profissional ele é excelente.

Então foi por esse motivo que eu perdoei ele duas vezes. Entendeu?

Por que eu sabia que era só num momento de raiva, de bebida, já ameacei ele, já impus que 
se ele chegar a me agredir mais, não vai ter próxima vez, daí eu não vou ter dó mesmo, não volto atrás mais entendeu? 


\section{DEPOIMENTO 4 \\ ANÁLISE IDEOGRÁFICA}

\begin{tabular}{|c|c|c|c|}
\hline $\begin{array}{l}\text { Unidades de significado } \\
\text { (linguagem do participante) }\end{array}$ & $\begin{array}{l}\text { Primeiras } \\
\text { Elucidações }\end{array}$ & $\begin{array}{l}\text { Linguagem } \\
\text { Pesquisador }\end{array}$ & $\begin{array}{l}\text { Unidades de Significado } \\
\text { (enfoque no fenômeno } \\
\text { interrogado) }\end{array}$ \\
\hline $\begin{array}{l}\text { 1. É uma situação difícil, humilhante, constrangedora, e a gente se sente muito mal } \\
\text { e, posso falar mais, desesperadora, que leva a fazer isto, entendeu? No momento } \\
\text { de nervoso, de dor, de humilhação, de raiva, de um monte de coisa a gente é } \\
\text { levada a fazer isto daí, prestar queixa, ir na delegacia prestar queixa, é isto daí. } \\
\text { 2. É, por que no meu caso, no meu caso que aconteceu isso, meu marido bebe, o } \\
\text { defeito dele é a bebida, ele é uma pessoa trabalhadora, não tem vícios, fora a } \\
\text { bebida. } \\
\text { 3. Ele não tem, assim, envolvimento com outros casos, de assim mulheres, não } \\
\text { tem amantes, nós não temos problemas com traição, não é o nosso caso e... } \\
\text { 4. ... ele é uma pessoa que bebe, ele fica muito valente quando bebe, ele se } \\
\text { transforma, fica com um comportamento agressivo... } \\
5 . . . \text { então, é onde a gente não pode falar nada, às vezes, eu respondo, é aonde ele } \\
\text { parte pra ignorância, que ele parte, assim pra agressão, fala assim coisas que a } \\
\text { gente não deve, entende? } \\
\text { 6. Que nem, comigo já aconteceu duas vezes, eu precisava procurar a policia } \\
\text { porque ele tava tão bêbado, tão bêbado, que ele tava assim violento demais e meu } \\
\text { medo, sei lá, que ele pegasse alguma faca, porque arma em casa a gente não tem, } \\
\text { foi ai que eu fiz a denúncia. }\end{array}$ & $\begin{array}{l}\text { vício: costume } \\
\text { prejudicial, mau hábito, } \\
\text { inclinação para o mal. } \\
\text { valente: Que apresenta } \\
\text { valentia -fanfarrice, } \\
\text { bravata. } \\
\text { Parte para a ignorância: } \\
\text { torna-se irracional e } \\
\text { agressivo. }\end{array}$ & $\begin{array}{l}\text { No momento da agressão sente- } \\
\text { se humilhação, coação, } \\
\text { desesperança e raiva, o que leva } \\
\text { a formalizar a queixa na } \\
\text { delegacia. } \\
\text { Embora o marido seja e } \\
\text { trabalhador, sem outros vícios, a } \\
\text { situação de violência é causada } \\
\text { pela bebida. } \\
\text { O casal não tem problemas com } \\
\text { fidelidade. } \\
\text { Quando bebe o marido se } \\
\text { comporta com agressividade e } \\
\text { fanfarrice. } \\
\text { É preciso cuidado ao conversar } \\
\text { com o marido sob efeito da } \\
\text { bebida, pois reage de forma } \\
\text { irracional e agressiva. } \\
\text { O episódio de violência repetiu- } \\
\text { se duas vezes, provocando medo } \\
\text { e levando a mulher a denunciar a } \\
\text { agressão. } \\
\text { A situação sem saída leva à }\end{array}$ & $\begin{array}{l}4.2 \text { A agressão é causada pala } \\
\text { bebida. } \\
\begin{array}{l}\text { A bebida provoca } \\
\text { comportamentos irracionais } \\
\text { e agressivos. }\end{array} \\
\text { (Coincide com a unidade 4.3) }\end{array}$ \\
\hline
\end{tabular}




\begin{tabular}{|c|c|c|c|}
\hline $\begin{array}{l}\text { Unidades de significado } \\
\text { (linguagem do participante) }\end{array}$ & $\begin{array}{l}\text { Pri } \\
\text { Elv }\end{array}$ & $\begin{array}{l}\text { Linguagem } \\
\text { Pesquisador }\end{array}$ & \begin{tabular}{l}
\multicolumn{3}{l}{ Unidades de Significado } \\
(enfoque no fenômeno \\
interrogado)
\end{tabular} \\
\hline $\begin{array}{l}\text { 7. E também, quando a gente vai fazer a denúncia, é uma situação muito } \\
\text { humilhante, que nem pra mim que sou mulher que sempre trabalhou fora de casa... } \\
\text { Minha família não teve essas coisas, aí a gente vai na hora do desespero mesmo e } \\
\text { se sente muito humilhada, de saber que a gente tá lá na delegacia e que tá sendo } \\
\text { obrigada a fazer isso, pra ver se a pessoa toma consciência, toma vergonha na } \\
\text { cara, para com essa bebida. } \\
\text { 8. Ele já fez isso duas vezes, a primeira eu levei o caso até o juiz, foi processado, o } \\
\text { juiz falou que, se ele fizesse isso de novo, ele seria preso, por causa de agredir. A } \\
\text { segunda, achei que deveria retirar, dar mais uma chance pra ele, eu achei que foi } \\
\text { assim, uma coisa impensada e porque envolve filhos, } 18 \text { anos, envolve um monte } \\
\text { de coisas, bens que a gente tem, e no caso a gente ia ter que vender tudo, e eu não } \\
\text { tava em condições de tomar partido pra fazer uma divisão de bens, eu doente, me } \\
\text { encontrava em tratamento e não tinha pra onde ir, dispor da casa... } \\
\text { 9. É uma situação muito complicada, os filhos menores, então eu achei que desta } \\
\text { vez passa, porque, depois que passa a bebida, ele é outra pessoa, eu já falei que ele } \\
\text { é uma pessoa muito responsável, o patrão dele adora ele, trabalha firme há } 23 \\
\text { anos. Só numa firma, como profissional ele é excelente. Então foi por esse motivo } \\
\text { que eu perdoei ele duas vezes. Entendeu? Por que eu sabia que era só num } \\
\text { momento de raiva, de bebida. } \\
\text { 10. Já ameacei ele, já impus que se ele chegar a me agredir mais, não vai ter } \\
\text { próxima vez, daí eu não vou ter dó mesmo, não volto atrás mais entendeu? }\end{array}$ & $\begin{array}{l}\text { ameaçar: procurar } \\
\text { amedrontar, intimidar. }\end{array}$ & $\begin{array}{l}\text { Mesmo reincidente na agressão, } \\
\text { a mulher retira a queixa, pois } \\
\text { solidariza-se com o marido e } \\
\text { deseja manter a situação } \\
\text { familiar. } \\
\text { O marido é uma pessoa } \\
\text { responsável e bom profissional. } \\
\text { Somente age agressivamente } \\
\text { quando está sob efeito da bebida. }\end{array}$ & $\begin{array}{l}\text { 4.6 A retirada da queixa deve-se } \\
\text { à afetividade pelo agressor e ao } \\
\text { desejo de manter a família. }\end{array}$ \\
\hline
\end{tabular}




\section{DEPOIMENTO 4}

\section{ARTICULAÇÃO DA IDÉIAS PELA PESQUISADORA}

A participante sente-se humilhada e constrangida na condição de denunciar o marido, com quem vive há 18 anos e com quem tem filhos. Justifica sua desistência de denunciá-lo pela situação familiar: encontrava-se doente na época da agressão e uma separação do casal comprometeria a situação financeira da família. Explica a violência do marido como que restrita a momentos delimitados: ele se torna agressivo e ameaçador apenas quando bebe; quando sóbrio, é responsável, profissional competente e respeitado. Ao denunciar a agressão, sua expectativa seria de que a ação da Delegacia da Mulher tornaria o marido consciente e seus atos, levando-o a deixar a bebida. Espera, também, manter o "bom comportamento" do marido com a ameaça de ir até o fim na denúncia, em caso de reincidência da agressão.

Contraditoriamente às suas expectativas, no seu depoimento ela relata que o comportamento do marido é reincidente, esta é a segunda vez que o denuncia. Na primeira vez, ele foi processado e o juiz comunicou-lhe que seria preso caso a situação se repetisse. Nesta segunda vez, ela resolveu retirar a queixa. 


\section{Depoimento 5}

Bom, de inicio achei bom prestar queixa por que eu me senti muito ameaçada, eu tinha medo dele, porque ele sabia que eu não ia fazer nada. Porque varias vezes ele me ameaçou e eu nunca fiz nada, mas a partir do momento que ele ficou sabendo que eu prestei queixa ele ficou com medo, e isso pra mim foi bom, me passou uma segurança, porque eu pude confiar na policia e saber que ele ia para, tanto que ele paro, ele desistiu de me ameaçar, ele me ameaçava muito e ele me deu um carro quando a gente convivia junto,ele me passou um carro e quando a gente se separou o carro ficou pra mim.

Quando ele soube que eu estava namorando, ele amassou meu carro inteiro,e me ameaçou, ameaçou meu namorado que agora é o atual marido, eu descobri que tava grávida, eu amiguei, ele me levava pra fazer o aborto, se eu quisesse, uma serie de coisas absurdas ele falou pra mim, ele falo pra mim que aceitaria o meu filho mesmo não sendo dele se eu voltasse com ele, e eu não quis, e quando ele ficou sabendo que eu não voltaria com ele, ele passou a ma ameaçar mais, ai ele começou a fazer escândalo no meu local de serviço, ele me parava na rua, eu passava ele me xingava, então ficou insuportável, foi aonde que eu resolvi prestar queixa dele, que ele ficou sabendo, ele parou de me ameaçar, ele ia no serviço do meu marido, agora não vai mais,, foi onde ele me deu sossego. Ele me achava bobinha, a partir do momento que eu fiz queixa ele ficou esperto em relação as ameaças que ele fazia.Ai ele parou de me ameaçar.

Eu não tenho mais medo dele, mas se eu fosse pra fazer de novo eu faria, eu ameaçaria eu prestaria queixa de novo, e todo mundo que sofre com esse tipo de coisa tem que procurar a delegacia, porque não é certo.

Agora eu tenho sossego, tranqüilidade eu vou aonde quero e ele não me perturba mais, agora ele me deu sossego. 


\section{DEPOIMENTO 5 \\ ANÁLISE IDEOGRÁFICA}

\begin{tabular}{|c|c|c|c|}
\hline $\begin{array}{l}\text { Unidades de significado } \\
\text { (linguagem do participante) }\end{array}$ & $\begin{array}{l}\text { Primeiras } \\
\text { Elucidações }\end{array}$ & $\begin{array}{l}\text { Linguagem } \\
\text { Pesquisador }\end{array}$ & $\begin{array}{l}\text { Unidades de Significado } \\
\text { (enfoque no fenômeno interrogado) }\end{array}$ \\
\hline $\begin{array}{l}\text { 1.... de início achei bom prestar queixa por que eu me } \\
\text { senti muito ameaçada, eu tinha medo dele, porque ele sabia } \\
\text { que eu não ia fazer nada. Porque varias vezes ele me } \\
\text { ameaçou e eu nunca fiz nada, } \\
\text { 2. ...mas, a partir do momento que ele ficou sabendo que } \\
\text { eu prestei queixa, ele ficou com medo, e isso pra mim foi } \\
\text { bom, me passou uma segurança, porque eu pude confiar na } \\
\text { policia e saber que ele ia parar, tanto que ele parou, ele } \\
\text { desistiu de me ameaçar, ele me ameaçava muito... } \\
\text { 3. Ele me deu um carro, quando a gente convivia junto, ele } \\
\text { me passou um carro e quando a gente se separou o carro } \\
\text { ficou pra mim. Quando ele soube que eu estava } \\
\text { namorando, ele amassou meu carro inteiro, e me ameaçou, } \\
\text { ameaçou meu namorado, que agora é o atual marido. } \\
\text { 4. Eu descobri que tava grávida, eu amiguei, ele me levava } \\
\text { pra fazer o aborto, se eu quisesse. Uma série de coisas } \\
\text { absurdas, ele falou pra mim, ele falou pra mim que } \\
\text { aceitaria o meu filho, mesmo não sendo dele, se eu } \\
\text { voltasse com ele. }\end{array}$ & $\begin{array}{l}\text { ameaçada: que recebeu } \\
\text { ameaças, sob risco. }\end{array}$ & $\begin{array}{l}\text { A formalização da queixa deixou } \\
\text { o agressor temeroso, desistindo } \\
\text { das ameaças. } \\
\text { Após a separação, o ex-marido } \\
\text { tomou atitudes agressivas contra } \\
\text { ela e o atual marido. } \\
\text { Tentando reconciliar-se, o ex- } \\
\text { marido propôs aceitar o filho do } \\
\text { atual marido, ou levá-la a fazer o } \\
\text { aborto. }\end{array}$ & $\begin{array}{l}5.2 \text { A formalização da queixa } \\
\text { intimida o agressor. } \\
\text { 5.3 A não-aceitação da separação } \\
\text { do casal pelo marido provoca } \\
\text { comportamentos irracionais e } \\
\text { agressivos por parte dele. }\end{array}$ \\
\hline
\end{tabular}




\begin{tabular}{|c|c|c|c|}
\hline $\begin{array}{l}\text { Unidades de significado } \\
\text { (linguagem do participante) }\end{array}$ & $\begin{array}{l}\text { Primeiras } \\
\text { Elucidações }\end{array}$ & $\begin{array}{l}\text { Linguagem } \\
\text { Pesquisador }\end{array}$ & $\begin{array}{l}\text { Unidades de Significado } \\
\text { (enfoque no fenômeno interrogado) }\end{array}$ \\
\hline $\begin{array}{l}5 . \text {... eu não quis, e quando ele ficou sabendo que eu não } \\
\text { voltaria com ele, ele passou a ma ameaçar mais, aí ele } \\
\text { começou a fazer escândalo no meu local de serviço; ele me } \\
\text { parava na rua, eu passava, ele me xingava, então ficou } \\
\text { insuportável, foi aonde que eu resolvi prestar queixa dele... } \\
\text { 6.... e que ele ficou sabendo, ele parou de me ameaçar, ele } \\
\text { ia no serviço do meu marido, agora não vai mais, foi onde } \\
\text { ele me deu sossego. } \\
\text { 7. Ele me achava bobinha, a partir do momento que eu fiz } \\
\text { queixa ele ficou esperto em relação as ameaças que ele } \\
\text { fazia.Ai ele parou de me ameaçar. } \\
\text { 8. Eu não tenho mais medo dele, mas se eu fosse pra fazer } \\
\text { de novo eu faria, eu ameaçaria, eu prestaria queixa de } \\
\text { novo, e todo mundo que sofre com esse tipo de coisa tem } \\
\text { que procurar a delegacia, porque não é certo. } \\
\text { 9. Agora eu tenho sossego, tranqüilidade eu vou aonde } \\
\text { quero e ele não me perturba mais, agora ele me deu } \\
\text { sossego. }\end{array}$ & $\begin{array}{l}\text { escândalo: tumulto, } \\
\text { cena, escarcéu. }\end{array}$ & $\begin{array}{l}\text { Não conseguindo reconciliar-se, } \\
\text { o ex-marido passou a fazer } \\
\text { ameaças e tumulto no seu local } \\
\text { de trabalho, o que motivou a } \\
\text { denúncia de agressão. } \\
\text { A formalização da queixa na } \\
\text { Delegacia fez o agressor cessar } \\
\text { as ameaças. }\end{array}$ & $\begin{array}{l}\text { (coincide com a unidade 5.2) } \\
\text { (coincide com a unidade 5.2) } \\
5.4 \text { Toda mulher agredida deve } \\
\text { exercer seus direitos, } \\
\text { registrando queixa contra o } \\
\text { agressor na Delegacia. } \\
\text { (coincide com a unidade 5.2) }\end{array}$ \\
\hline
\end{tabular}




\section{DEPOIMENTO 5}

\section{ARTICULAÇÃO DAS IDÉIAS PELA PESQUISADORA}

A participante é casada com outro e estava sendo ameaçada pelo agressor, ex-companheiro, que a assediava, tentando fazê-la voltar a viver com ele. Após sofrer muitas ameaças e agressões, ela foi à Delegacia formalizar queixa contra ele, que se atemorizou com o processo legal e deixou-a em paz.

A participante valoriza este instrumento legal de que a mulher dispõe: a Delegacia da Mulher. Porém, contraditoriamente, ao obter resultado positivo pela denúncia, resolveu retirá-la.

Afirma que faria novamente a denúncia se necessário, pois ele passou a respeitá-la depois de sua atitude. 


\section{Depoimento 6}

No momento eu senti humilhada, com medo, pedi uma ajuda porque ele bebe, ele ameaça matar eu e meus filhos e me botar pra fora de casa, mas tudo isso dentro da bebida.

Na primeira vez que eu fui foi registrado a ocorrência na Delegacia dos Homens. Ai depois veio a intimação pra ir na Delegacia da Mulher só ele.

Ele foi chamado lá, falaram ele mudou, mudou muito, ele ficou uns seis meses que é uma maravilham, mas depois voltou tudo de novo, agora da ultima vez ele me ameaçou de novo, $e$ partiu pra cima de mim, ai eu fui na delegacia dar queixa, ai só que eu fui direto na delegacia da mulher. Só que cheguei lá, eu não fui pedir ajuda e eu não me senti assim fortalecida lá também. Ele tava novamente bêbado, ai eu peguei, registrei a queixa lá. Aí, dias depois eles mandaram uma intimação, que eu só vim saber uma semana depois que a delegada ligou pra mim avisando.

E a retirada da queixa não foi assim, medo de enfrentar ele, lá, esse não foi o medo, eu penso assim, se o culpado é ele, porque eu tenho que ta junto? Eu queria que ele só pagasse pelos erros dele, e que fizessem ele entender que mulher não é pra ser usada na cama ou em outro lugar, é pra ser respeitada, quero que chamem ele lá e dêem uma lição de moral que ele precisa levar mesmo. É essa minha verdade, é isso que eu quero que aconteça.

Porque quando ele esta sóbrio, ah eu não fiz isso e outra quando sempre que ele bebe ele, ofende, ele ameaça, ele xinga, ele faz aquele escândalo, ninguém dorme cedo ai no outro dia ele se posa de vitima. Na delegacia da mulher, eles vão acreditar na minha palavra, mas, eu não vou poder fazer nada por mim também. Eu falo pra ele, eu também trabalho, chego tarde eu to em casa e na maioria da vezes tem semana que ele bebe que é um condenado, tem semana que não. Eu preciso de alguém que fale pra ele o que é o certo é certo o que é o errado é o errado, é assim que eu quero que as coisas sejam. Quem nem da outra vez, foi assim, né, eu não sei qual foi a Delegada que chamou ele lá e tudo, quem conversou com ele, mas, seja lá quem foi, deixou ele com bastante medo, porque ele tem muito medo de policia, viu, seja lá quem foi botou muito medo nele, sim, e mas, ele pode ta ai dando os pulo dele dentro de casa, ce falo em chama a policia ele abaixa em dois tempos. Isso é sinal que a bebida dele é o que de conveniência, é de conveniência, isso é que nem muitos outros homens por ai faz, bebe pra se ter coragem de chegar em casa e botar a familia par correr ou judiar da familia dentro de casa, eu penso que é assim, por que os outro vai se diferente. O álcool acho que faz efeito igual pra todos que bebe ele, viu. Realmente é assim que eu penso que as coisas são. Eu não tenho mais nada pra declarar. 
DEPOIMENTO 6

ANÁLISE IDEOGRÁFICA

\begin{tabular}{|c|c|c|c|}
\hline $\begin{array}{l}\text { Unidades de significado } \\
\text { (linguagem do participante) }\end{array}$ & $\begin{array}{l}\text { Primeiras } \\
\text { Elucidações }\end{array}$ & $\begin{array}{l}\text { Linguagem do } \\
\text { Pesquisador }\end{array}$ & \begin{tabular}{l}
\multicolumn{3}{l}{ Unidades de Significado } \\
(enfoque no fenômeno \\
interrogado)
\end{tabular} \\
\hline $\begin{array}{l}\text { 1. No momento eu senti humilhada, com medo, pedi uma } \\
\text { ajuda, porque ele bebe, ele ameaça matar eu e meus filhos e me } \\
\text { botar pra fora de casa, mas tudo isso dentro da bebida. } \\
2 \text { Na primeira vez que eu fui, foi registrado a ocorrência na } \\
\text { Delegacia dos Homens. Aí, depois veio a intimação pra ir na } \\
\text { Delegacia da Mulher, só ele. Ele foi chamado lá, falaram, ele } \\
\text { mudou, mudou muito, ele ficou uns seis meses que é uma } \\
\text { maravilha. Mas, depois, voltou tudo de novo. } \\
\text { 3. Agora, da ultima vez ele me ameaçou de novo e partiu pra } \\
\text { cima de mim, aí eu fui na delegacia dar queixa, só que eu fui } \\
\text { direto na delegacia da mulher. Só que cheguei lá, eu não fui } \\
\text { pedir ajuda e eu não me senti assim fortalecida lá, também. Ele } \\
\text { tava novamente bêbado, aí eu peguei, registrei a queixa lá. Aí, } \\
\text { dias depois, eles mandaram uma intimação, que eu só vim } \\
\text { saber uma semana depois que a delegada ligou pra mim } \\
\text { avisando. } \\
\text { 4. E a retirada da queixa não foi, assim, medo de enfrentar ele } \\
\text { lá, esse não foi o medo. Eu penso assim, se o culpado é ele, } \\
\text { porque eu tenho que tá junto? Eu só queria que ele pagasse }\end{array}$ & $\begin{array}{l}\text { Delegacia dos Homens: } \\
\text { refere-se à Delegacia } \\
\text { comum, que atendia as } \\
\text { mulheres vítimas de } \\
\text { violência antes de ser } \\
\text { instituída a Delegacia } \\
\text { da Mulher. } \\
\text { Receber intimação da } \\
\text { Delegacia da Mulher: } \\
\text { no contexto, a mulher } \\
\text { somente é intimada } \\
\text { para comparecer à } \\
\text { Delegacia junto com o } \\
\text { agressor: } 1^{\circ} \text { se for } \\
\text { necessária a realização } \\
\text { de acareação; } 2^{\circ} \text { na } \\
\text { audiência de } \\
\text { conciliação. (Nucci, } \\
\text { 2003) }\end{array}$ & $\begin{array}{l}\text { No momento da agressão, } \\
\text { pediu ajuda por sentir medo } \\
\text { do marido violento, sob } \\
\text { efeito da bebida. } \\
\text { Após o registro da primeira } \\
\text { queixa contra o marido, ele } \\
\text { passou seis meses } \\
\text { comportando-se bem, mas } \\
\text { voltou a agredir. }\end{array}$ & $\begin{array}{l}6.1 \text { A queixa contra a agressão } \\
\text { pelo marido é motivada pela } \\
\text { ameaça à sua vida e a de seus filhos. } \\
6.2 \text { A denúncia tem efeito } \\
\text { repressivo sobre o comportamento } \\
\text { agressivo, mas depois este reincide. }\end{array}$ \\
\hline
\end{tabular}




\begin{tabular}{|c|c|c|c|}
\hline $\begin{array}{l}\text { Unidades de significado } \\
\text { (linguagem do participante) }\end{array}$ & $\begin{array}{l}\text { Primeiras } \\
\text { Elucidações }\end{array}$ & $\begin{array}{l}\text { Linguagem do } \\
\text { Pesquisador }\end{array}$ & \begin{tabular}{l}
\multicolumn{3}{l}{ Unidades de Significado } \\
(enfoque no \\
interrogado)
\end{tabular} \\
\hline $\begin{array}{l}\text { pelos erros dele, e que fizessem ele entender que mulher não é } \\
\text { pra ser usada na cama ou em outro lugar, é pra ser respeitada: } \\
\text { quero que chamem ele lá e dêem uma lição de moral, que ele } \\
\text { precisa levar mesmo. É essa minha verdade, é isso que eu } \\
\text { quero que aconteça. } \\
\text { 5. Porque quando ele está sóbrio: 'Ah! eu não fiz isso', e outra, } \\
\text { sempre que ele bebe ele ofende, ele ameaça, ele xinga, ele faz } \\
\text { aquele escândalo, ninguém dorme cedo, aí no outro dia ele se } \\
\text { posa de vítima. } \\
\text { 6. Na delegacia da mulher, eles vão acreditar na minha palavra, } \\
\text { mas não vão poder fazer nada por mim, também. Eu falo pra } \\
\text { ele: eu também trabalho, chego tarde em casa, e na maioria da } \\
\text { vezes, tem semana que ele bebe que é nem condenado, tem } \\
\text { semana que não. Eu preciso de alguém que fale pra ele o que é } \\
\text { o certo e o que é errado, é assim que eu quero que as coisas } \\
\text { sejam. Quem nem da outra vez, foi assim, eu não sei qual foi a } \\
\text { Delegada que chamou ele lá e tudo, quem conversou com ele, } \\
\text { mas, seja lá quem foi, deixou ele com bastante medo, porque } \\
\text { ele tem muito medo de policia, viu? Seja lá quem foi, botou } \\
\text { muito medo nele, sim ...e mais, ele pode tá ai dando os pulo } \\
\text { dele dentro de casa, você falou em chamar a policia, ele abaixa }\end{array}$ & $\begin{array}{l}\text { lição de moral: } \\
\text { preleção sobre como } \\
\text { comportar-se. } \\
\text { verdade: convicção, } \\
\text { justeza, opinião, ponto } \\
\text { de vista. }\end{array}$ & $\begin{array}{l}\text { A queixa foi retirada devido } \\
\text { à convocação para que ela } \\
\text { comparecesse à Delegacia, o } \\
\text { que ela avaliou como } \\
\text { injusto, pois seria o marido } \\
\text { o culpado, não ela. Apenas } \\
\text { ele precisaria ser } \\
\text { repreendido. } \\
\text { Quando está sóbrio o } \\
\text { marido não se lembra de sua } \\
\text { atitude agressiva. }\end{array}$ & $\begin{array}{l}\text { 6.4 A mulher considera que ser } \\
\text { chamada à Delegacia significa ser } \\
\text { punida, como o agressor. } \\
6.5 \text { O comportamento sob efeito da } \\
\text { bebida é esquecido pelo agressor. }\end{array}$ \\
\hline
\end{tabular}




\begin{tabular}{|c|c|c|c|}
\hline $\begin{array}{c}\text { Unidades de significado } \\
\text { (linguagem do participante) }\end{array}$ & $\begin{array}{l}\text { Primeiras } \\
\text { Elucidaçóes }\end{array}$ & $\begin{array}{l}\text { Linguagem do } \\
\text { Pesquisador }\end{array}$ & $\begin{array}{lll}\text { Unidades de Significado } \\
\text { (enfoque no } \\
\text { interrogado) }\end{array}$ \\
\hline $\begin{array}{l}\text { em dois tempo. } \\
\text { 7.Isso é sinal que a bebida dele é o que é de conveniência, é de } \\
\text { conveniência; isso é que nem muitos outros homens por aí faz, } \\
\text { bebe pra se ter coragem de chegar em casa e botar a família pra } \\
\text { correr ou judiar da família dentro de casa. Eu penso que é } \\
\text { assim, por que os outro vai se diferente? O álcool acho que faz } \\
\text { efeito igual pra todos que bebe ele, viu? Realmente, é assim } \\
\text { que eu penso que as coisas são. Eu não tenho mais nada pra } \\
\text { declarar. }\end{array}$ & $\begin{array}{l}\text { de conveniência: } \\
\text { conveniente, vantajoso, } \\
\text { cômodo. } \\
\text { coragem: ousadia, } \\
\text { atrevimento, } \\
\text { imprudência. }\end{array}$ & $\begin{array}{l}\text { Como para muitos homens, } \\
\text { a bebida seria conveniente } \\
\text { para estimular a comportar- } \\
\text { se com atrevimento, ao } \\
\text { agredir a família toda. }\end{array}$ & $\begin{array}{l}6.7 \text { A bebida estimula os } \\
\text { comportamentos agressivo com a } \\
\text { família. }\end{array}$ \\
\hline
\end{tabular}




\section{DEPOIMENTO 6}

\section{ARTICULAÇÃO DAS IDÉIAS PELA PESQUISADORA}

A participante fez a primeira queixa na Delegacia Geral e o marido foi intimado para comparecer à Delegacia da Mulher. Passou a comportar-se bem por seis meses, depois voltou a apresentar atitudes agressivas. Após a segunda agressão, ela voltou a registrar queixa, desta vez na Delegacia de Mulher, e considera que ali não se sentiu apoiada: foi convocada para comparecer, ela também. Avaliou que não deveria ser intimada, pois é ele o culpado pela situação, não ela; por este motivo, retirou a queixa. Seu objetivo, ao registrar a denúncia, seria que o companheiro fosse repreendido e aprendesse a respeitá-la. Como avalia ter aconteceu na primeira vez. Afirma que o marido tem muito medo de polícia e comporta-se quando ameaçado de ser denunciado. Considera que o alcoolismo é conveniente para o marido, que utiliza a bebida para mostrar-se forte e corajoso e maltratar a família. No seu entender, somente a polícia poderia corrigir este comportamento. 


\section{Depoimento 7}

A primeira vez que eu apanhei eu fiquei nervosa, com vontade de vir aqui, de me abrir com todo mundo, aqui na Delegacia, assim, mas na hora da raiva eu vim, tudo, conversei, depois a gente ficou separado, algum tempinho, dai a gente resolveu voltar. Agora na segunda vez que eu to morando com minha mãe, ele me agrediu de novo e eu senti muita raiva, muito nervosa, resolvi voltar aqui, só que dai teve todas essas coisas de advogado de processar ele. Daí tudo bem, aceitei fazer, mais quando a gente chega em casa a gente fica mais calma aí a gente muda a cabeça e decidimos conversa, a gente continuou no mesmo teto, só que afastado, até que a gente resolveu dar mais um chance, e ele ta passando por psicólogo agora e eu gosto muito dele, mas, acho que ele muda, ele pode muda também.

Eu não me arrependi muito, mais agora eu to retirando porque quem sabe, ele vai melhorar,a gente entro numa, agora ele ta mais calmo, agora ele conversa, ta bem melhor depois que eu vim aqui.

Eu acho que todas as mulheres deveriam fazer isso. Muitas desistem igual eu desisti, me arrependo um poço por ter desistido, mas eu quero tentar mais uma vez, dar mais um chance pra ver como é que é, mas caso assim piore, acho que ninguém deve desistir. 


\section{DEPOIMENTO 7}

\section{ANÁLISE IDEOGRÁFICA}

\begin{tabular}{|c|c|c|c|}
\hline $\begin{array}{l}\text { Unidades de significado } \\
\text { (linguagem do participante) }\end{array}$ & Primeiras Elucidações & $\begin{array}{l}\text { Linguagem } \\
\text { Pesquisador }\end{array}$ & $\begin{array}{l}\text { Unidades de Significado } \\
\text { (enfoque no fenômeno interrogado) }\end{array}$ \\
\hline $\begin{array}{l}\text { 1. A primeira vez que eu apanhei, eu fiquei nervosa, } \\
\text { com vontade de vir aqui, de me abrir com todo mundo } \\
\text { aqui na Delegacia. Assim, mas na hora da raiva eu vim, } \\
\text { tudo, conversei, depois a gente ficou separado, algum } \\
\text { tempinho, daí a gente resolveu voltar. } \\
2 \text {. Agora na segunda vez que eu tô morando com minha } \\
\text { mãe, ele me agrediu de novo e eu senti muita raiva, } \\
\text { muito nervosa, resolvi voltar aqui, só que daí teve todas } \\
\text { essas coisas de advogado de processar ele. Daí tudo } \\
\text { bem, aceitei fazer. } \\
\text { 3. Mas, quando a gente chega em casa, a gente fica } \\
\text { mais calma, aí a gente muda a cabeça e decidimos } \\
\text { conversar. A gente continuou no mesmo teto, só que } \\
\text { afastado, até que a gente resolveu dar mais um chance, } \\
\text { e ele tá passando por psicólogo agora e eu gosto muito } \\
\text { dele, mas, acho que ele muda, ele pode mudar também. } \\
\text { 4. Eu não me arrependi muito, mas agora eu tô } \\
\text { retirando porque quem sabe ele vai melhorar? A gente } \\
\text { entrou numa, agora ele tá mais calmo, agora ele } \\
\text { conversa, tá bem melhor depois que eu vim aqui. }\end{array}$ & $\begin{array}{l}\text { O advogado processar: } \\
\text { segundo o processo Penal } \\
\text { Brasileiro, cabe à pessoa } \\
\text { agredida, apresentando } \\
\text { lesões não graves, decidir- } \\
\text { se, ou não, por processa o } \\
\text { agressor. }\end{array}$ & $\begin{array}{l}\text { A participante foi agredida } \\
\text { anteriormente, apresentou } \\
\text { queixa contra o marido, } \\
\text { separou-se um tempo e } \\
\text { voltou a viver com ele. } \\
\text { Após a segunda agressão, } \\
\text { aceitou processar o marido } \\
\text { pela agressão. } \\
\text { Em casa, ela e o marido } \\
\text { chegaram a um acordo de } \\
\text { continuar juntos, ele } \\
\text { tratando-se com psicólogo, } \\
\text { Ela espera que ele mude seu } \\
\text { comportamento. }\end{array}$ & $\begin{array}{l}7.2 \text { A repetição da agressão leva a } \\
\text { mulher a tomar atitude judicial contra o } \\
\text { marido. } \\
7.3 \text { Após a queixa, há a reconciliação e } \\
\text { a esperança que o marido mude. }\end{array}$ \\
\hline
\end{tabular}




\begin{tabular}{|l|l|l|l|}
\hline \multicolumn{1}{|c|}{$\begin{array}{c}\text { Unidades de significado } \\
\text { (linguagem do participante) }\end{array}$} & Primeiras Elucidações & $\begin{array}{l}\text { Linguagem do } \\
\text { Pesquisador }\end{array}$ & $\begin{array}{l}\text { Unidades de Significado } \\
\text { (enfoque no fenômeno interrogado) }\end{array}$ \\
\hline $\begin{array}{l}\text { 5. Eu acho que todas as mulheres deveriam fazer isso. } \\
\text { Muitas desistem, igual eu desisti, me arrependo um } \\
\text { pouco por ter desistido. }\end{array}$ & $\begin{array}{l}\text { Todas as mulheres agredidas } \\
\text { deveriam fazer queixa e levar } \\
\text { adiante, arrepende-se de ter } \\
\text { desistido. }\end{array}$ & $\begin{array}{l}\text { 7.4 As mulheres agredidas devem } \\
\text { registrar queixa e não desistir. } \\
\text { 6. Mas eu quero tentar mais uma vez, dar mais um } \\
\text { chance pra ver como é que é, mas caso, assim, piore, } \\
\text { acho que ninguém deve desistir. }\end{array}$ & $\begin{array}{l}\text { casamento. } \\
\text { violência manteméstica, desejam manter o } \\
\text { casamento. }\end{array}$ \\
\hline
\end{tabular}




\section{DEPOIMENTO 7}

\section{ARTICULAÇÃO DAS IDÉIAS PELA PESQUISADORA}

A participante foi agredida fisicamente pelo marido pela segunda vez. A raiva levou-a à Delegacia para fazer a denúncia e separar-s dele. Voltou a viver com o marido e a situação repetiu-se, voltando para a casa da mãe. Nesta segunda vez, após a raiva, conversou com o marido e resolveram voltar a viver juntos. Ele faz, atualmente, tratamento com psicólogo e ela espera que ele mude. Não se arrependeu de denunciá-lo e pensa que ele melhorou o comportamento depois da denúncia, por este motivo retirou-a.

Avalia que as mulheres devem denunciar, embora depois desistam. Diz que, se a situação repetirse, não deverá desistir. Sua atitude mostra-se ambígua: acredita na denúncia e defende-a, mas justifica a desistência. 


\section{Depoimento 8}

A minha experiência foi assim é... foi triste ficou muito chato o ambiente pelo meu filho também, que ele ficou. achei que ele ficou mais agressivo, que ele já é um pouco agressivo e também a minha familia veio até a casa saber do acontecimento e eles, pedindo que eu fosse denunciar. Você tá nervosa ... bastante abatida com o aconteceu, triste e... fui até a delegacia fazer a denuncia ... E depois eu me senti muito mal sabe, eu não conseguia dormir. Fiquei muito mal mesmo, muito mal e o filho parecia que cobrava da gente alguma coisa, porque o pai é bom, ele é muito bom. Tem a parte, tem a parte dele que tem muitos problemas, é nervoso, e mais, porque a gente tava se sentindo traída, muito traída e, ah...e mais... Aí depois eu desisti, fui desistir da denuncia, que nós ficamos muito sem saber o que fazia, nervoso um com o outro, ele não ficou em casa, saiu, aí foi mais pelo meu filho também, aí eu fui retirar a queixa. É que a gente tava se sentindo muito mal com aquilo, porque foi outras pessoas também que pediu pra que a gente fosse e na hora do nervosismo... Depois vem o arrependimento e hoje, uma semana atrás, ele voltou pra casa. Me trata, ma dá tratamento melhor, ainda continua nervoso porque ele sempre é, desde que nos casamos.

Pensar bastante antes, que as vezes nem dá mesmo pra gente pensar porque na hora do nervosismo você não ta nem sabendo o que ta fazendo e outra... procurar algum conselho melhor, assim, uma pessoa que te aconselhe o que você deve saber ou não. 
DEPOIMENTO 8

ANÁLISE IDEOGRÁFICA

\begin{tabular}{|c|c|c|c|}
\hline $\begin{array}{l}\text { Unidades de significado } \\
\text { (linguagem do parti } \\
\text { cipante) }\end{array}$ & Primeiras Elucidações & $\begin{array}{l}\text { ggem do } \\
\text { lisador }\end{array}$ & $\begin{array}{l}\text { Unidades de Significado } \\
\text { (enfoque no fenômeno } \\
\text { interrogado) }\end{array}$ \\
\hline $\begin{array}{l}\text { 1. ... foi triste, ficou muito chato o ambiente; pelo meu } \\
\text { filho também, que ele ficou.. achei que ele ficou mais } \\
\text { agressivo, que ele já é um pouco agressivo. } \\
\text { 2. E também a minha familia veio até a casa saber do } \\
\text { acontecimento e eles, pedindo que eu fosse denunciar. } \\
\text { Você tá nervosa, e... bastante abatida com o que aconteceu, } \\
\text { triste e... fui até a delegacia fazer a denuncia... } \\
\text { 3. E depois eu me senti muito mal, sabe? Eu não } \\
\text { conseguia dormir, fiquei muito mal mesmo, muito mal, } \\
\text { 4. ... e o filho parecia que cobrava da gente alguma coisa, } \\
\text { porque o pai é bom, ele é muito bom. } \\
5 \text {. Tem a parte, tem a parte dele que tem muitos problemas, } \\
\text { é nervoso, e mais, porque a gente tava se sentindo traída, } \\
\text { muito traída... que mais? } \\
6 \text {. Aí depois eu desisti, fui desistir da denúncia, que nós } \\
\text { ficamos muito sem saber o que fazia, nervoso um com o } \\
\text { outro. Ele não ficou em casa, } \\
\text { 7. ... aí foi mais pelo meu filho também, aí eu fui retirar a } \\
\text { queixa: é que a gente tava se sentindo muito mal com } \\
\text { aquilo, porque foi outras pessoas também que pediu pra }\end{array}$ & $\begin{array}{l}\text { cobrar: pedir, exigir. } \\
\text { cobrar alguma coisa: no } \\
\text { texto - recriminar a } \\
\text { atitude } \\
\text { nervoso: que sofre de } \\
\text { nervosismo; irritadiço; } \\
\text { traída: que sofre } \\
\text { deslealdade. } \\
\text { que: porque }\end{array}$ & $\begin{array}{l}\text { O filho recriminava-a pois o pai } \\
\text { é bom. } \\
\text { O marido tem problemas e é } \\
\text { irritadiço, e ela se sentia traída, } \\
\text { pela sua deslealdade em agredi- } \\
\text { la. na sua confiança. } \\
\text { Não sabendo o que fazer para } \\
\text { resolver o mal-estar com o } \\
\text { marido, resolveu retirar a } \\
\text { denúncia. } \\
\text { A desistência também foi } \\
\text { motivada pela reação do filho e }\end{array}$ & 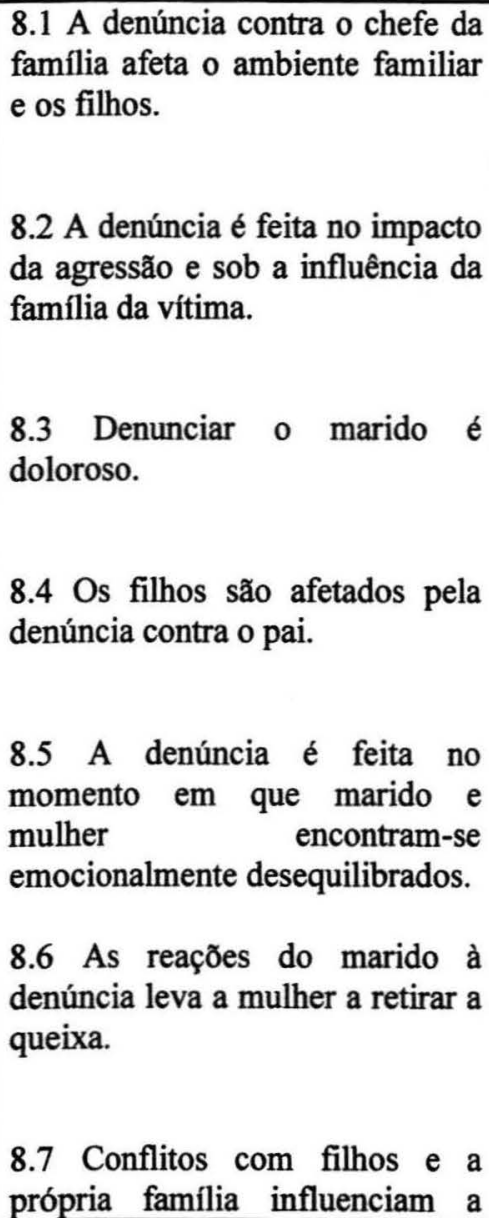 \\
\hline
\end{tabular}




\begin{tabular}{|c|c|c|c|}
\hline $\begin{array}{c}\text { Unidades de significado } \\
\text { (linguagem do parti } \\
\text { cipante) }\end{array}$ & Primeiras Elucidações & $\begin{array}{l}\text { Linguagem do } \\
\text { Pesquisador }\end{array}$ & $\begin{array}{c}\text { Unidades de Significado } \\
\text { (enfoque no fenômeno } \\
\text { interrogado) }\end{array}$ \\
\hline $\begin{array}{l}\text { que a gente fosse, e... } \\
\text { 8. ...depois vem o arrependimento, e hoje, uma semana } \\
\text { atrás, ele voltou pra casa. Me trata, me dá tratamento } \\
\text { melhor, ainda continua nervoso porque ele sempre é, desde } \\
\text { que nos casamos. } \\
\text { 9. Pensar bastante antes, que às vezes nem dá mesmo pra } \\
\text { gente pensar, porque na hora do nervosismos você não tá } \\
\text { nem sabendo o que tá fazendo; e outra... procurar algum } \\
\text { conselho melhor, assim, uma pessoa que te aconselhe o } \\
\text { que você deve fazer ou não. }\end{array}$ & $\begin{array}{l}\text { pensar: raciocinar, } \\
\text { refletir, elaborar juízos, } \\
\text { analisar, julgar. } \\
\text { não está sabendo o que } \\
\text { está fazendo: não está } \\
\text { consciente das suas ações. }\end{array}$ & $\begin{array}{l}\text { porque a decisão de denunciar } \\
\text { foi tomada sob a influência de } \\
\text { outras pessoas. } \\
\text { Depois de retirada da queixa, o } \\
\text { marido arrependeu-se da } \\
\text { agressão e voltou para casa e a } \\
\text { trata melhor, embora continue } \\
\text { nervoso. } \\
\text { A participante avalia que, antes } \\
\text { de denunciar o marido por } \\
\text { agressão, é preciso refletir e } \\
\text { analisar a situação, pois quando } \\
\text { está sob o impacto da agressão } \\
\text { sofrida a mulher não está } \\
\text { consciente do que faz. }\end{array}$ & $\begin{array}{l}\text { denúncia e a desistência. } \\
\text { 8.8 Após o processo denúncia- } \\
\text { desistência o marido arrepende-se } \\
\text { e volta para casa, aparentemente } \\
\text { mudando seu comportamento. } \\
\text { 8.9 A mulher agredida sente } \\
\text { culpa e arrependimento após } \\
\text { denunciar o companheiro. }\end{array}$ \\
\hline
\end{tabular}




\section{DEPOIMENTO 8}

\section{ARTICULAÇÃO DAS IDÉIAS PELA PESQUISADORA}

A participante descreve a trajetória de denunciar o marido e desistir da queixa como uma experiência triste e desagradável, que tornou o filho mais agressivo. A denúncia foi feita sob a influência da sua família, no impacto da agressão. Sentiu-se muito mal após denunciá-lo, pois o marido é bom, apesar de nervoso. Sob pressão do filho e avaliando que foi precipitada, arrependeu-se e retirou a queixa. O marido voltou para casa e a trata melhor, apesar de continuar nervoso.

Avalia que é preciso pedir ajuda e orientação antes de tomar alguma atitude. É ambígua neste aspecto: não esclarece se é em relação à queixa ou à desistência da queixa. Mostra muita insegurança sobre suas atitudes. 


\section{Depoimento 9}

Bom, minha experiência de ir denunciar foi muito triste, foi muito dificil, porque chegou a um ponto que a gente é casado a 11 anos; moramos juntos a 11 anos, temos um filho e ver que não dá mais o casamento e ele não aceitar, a gente ter que vir, ele começou a me agredir por isso, ter que vir denunciar, o pai do meu filho por agressão é uma situação muito dificil, não conseguir resolver só por palavras, é ser muito exposto; expor meus filhos. E foi muito dificil de ta retirando esta denúncia, é perceber que ele está muito arrependido, dele está sofrendo muito com isso e, por ele estar muito doente, ele está, eu já fiz outros, esta não é a primeira vez que eu fiz denúncia contra ele, já foi feita outra denúncia, mas não foi levado adiante, não por mim, não sei porque não foi levado adiante, porque não recebi intimação é,... quando eu fui... quando meu marido me agredia; ele me agredia na frente dos meus filhos, na rua e ele só não me agredia com força física, me agredia psicologicamente, eh... Ele falava na minha cabeça várias e várias horas e deixava o meu horário de almoço, perdia do meu serviço com ele falando na minha cabeça, ele não aceitava a separação, ele não aceitando ele falava, falava. Ele falava e ele via que não tinha como, ele partia para a violência. Bom o que me motivou a vir fazer a denúncia é que ele me agrediu muito, na rua mesmo atrapalhando do meu serviço, é tirou meus filhos da escola, levou lá pra ver eu naquele estado, então eu via que não tinha mais jeito, que eu tinha que procurar meus direito, que não pode fazer isto, que não pode continuar fazendo isto comigo, eu acho que, que ninguém tem o direito de impedir as pessoas de fazerem, o que elas querem o que elas estão sentindo, eu acho que violência, por uma decisão minha não está certo, eu tenho a decisão e ter que apanhar por isso.

Então, eu estou desistindo da denúncia pelo estado de saúde dele, ele está muito doente e eu não quero cobrança dos meus filhos mais tarde, que apesar do pai deles me agredir, ele sabe que o pai dele, demonstra que gosta muito de mim, que não aceita pelo este amos, que é um amor doentio, e, e, como ele está muito doente, eu não quero que meus filhos cobrem de mim futuramente se acontecer alguma coisa, então vou dar uma nova oportunidade mas eu não vou sofrer violência de novo. 
DEPOIMENTO 9

ANÁLISE IDEOGRÁFICA

\begin{tabular}{|c|c|c|c|}
\hline $\begin{array}{l}\text { Un } \\
\text { (ling }\end{array}$ & $\begin{array}{l}\text { eiras } \\
\text { ações }\end{array}$ & $\begin{array}{l}\text { Linguagem do } \\
\text { Pesquisador }\end{array}$ & $\begin{array}{c}\text { Unidades de Significado } \\
\text { (enfoque no fenômeno interrogado) }\end{array}$ \\
\hline $\begin{array}{l}\text { 1. Bom, minha experiência de ir denunciar foi muito } \\
\text { triste, foi muito difícil... } \\
2 \ldots \text { porque chegou a um ponto que a gente é casado há } \\
11 \text { anos; moramos juntos há } 11 \text { anos, temos um filho. E } \\
\text { ver que não dá mais o casamento e ele não aceitar, a } \\
\text { gente ter que vir. Ele começou a me agredir por isso, } \\
\text { ter que vir denunciar, o pai do meu filho por agressão: } \\
\text { é uma situação muito dificil, não conseguir resolver só } \\
\text { por palavras, é ser muito exposto; expor meus filhos. } \\
\text { 3. E foi muito difícil de tá retirando esta denúncia, e } \\
\text { perceber que ele está muito arrependido, ele está } \\
\text { sofrendo muito com isso e, por ele estar muito doente, } \\
\text { ele está. } \\
\text { 3. Eu já fiz outras, esta não é a primeira vez que eu fiz } \\
\text { denúncia contra ele. Já foi feita outra denúncia, mas } \\
\text { não foi levado adiante, não por mim, não sei porque } \\
\text { não foi levado adiante, porque não recebi intimação... } \\
\text { 5. Quando meu marido me agredia, ele me agredia na } \\
\text { frente dos meus filhos, na rua, e ele não me agredia só } \\
\text { com força fisica, me agredia psicologicamente...Ele }\end{array}$ & $\begin{array}{lr}\text { intimação: após a } \\
\text { denúncia na Delegacia, } \\
\text { os envolvidos } & \text { são } \\
\text { convocados } & \text { para } \\
\text { depoimentos. } & \\
& \\
\text { falar na rabeça: } \\
\text { interpretação } & \text { no } \\
\text { contexto }- & \text { repetição } \\
\text { excessiva e } & \text { constante }\end{array}$ & $\begin{array}{l}\text { A denúncia da agressão, que foi } \\
\text { causada pelo fato de o marido } \\
\text { não aceitar a separação, expôs a } \\
\text { situação da família e o filho } \\
\text { publicamente. }\end{array}$ & $\begin{array}{l}9.2 \text { A denúncia expõe publicamente a } \\
\text { família. }\end{array}$ \\
\hline
\end{tabular}




\begin{tabular}{|c|c|c|c|}
\hline $\begin{array}{l}\text { Unidades de significado } \\
\text { (linguagem do participante) }\end{array}$ & $\begin{array}{c}\text { Primeiras } \\
\text { Elucidações }\end{array}$ & $\begin{array}{l}\text { Linguagem do } \\
\text { Pesquisador }\end{array}$ & $\begin{array}{l}\text { Unidades de Significado } \\
\text { (enfoque no fenômeno interrogado) }\end{array}$ \\
\hline $\begin{array}{l}\text { falava na minha cabeça, várias e várias horas, e deixava } \\
\text { o meu horário de almoço, perdia o meu serviço, com } \\
\text { ele falando na minha cabeça. } \\
\text { 6. Ele não aceitava a separação, ele não aceitando ele } \\
\text { falava, falava. Ele falava e ele via que não tinha como, } \\
\text { ele partia para a violência. } \\
\text { 7. Bom, o que me motivou a vir fazer a denúncia é que } \\
\text { ele me agrediu muito, na rua mesmo, atrapalhando o } \\
\text { meu serviço, tirou meus filhos da escola, levou lá pra } \\
\text { ver eu naquele estado...Então eu via que não tinha mais } \\
\text { jeito, que eu tinha que procurar meus direito, que não } \\
\text { pode fazer isto, que não pode continuar fazendo isto } \\
\text { comigo... eu acho que, que ninguém tem o direito de } \\
\text { impedir as pessoas de fazerem o que elas querem, o } \\
\text { que elas estão sentindo... Eu acho que esta violência, } \\
\text { por uma decisão minha, não está certo, eu tenho a } \\
\text { decisão e ter que apanhar por isso? } \\
\text { 8. Então, eu estou desistindo da denúncia pelo estado } \\
\text { de saúde dele, ele está muito doente e eu não quero } \\
\text { cobrança dos meus filhos mais tarde. Que, apesar do } \\
\text { pai deles me agredir, eles sabem que o pai deles }\end{array}$ & $\begin{array}{l}\text { fazerem o que querem: } \\
\text { no contexto, fazerem as } \\
\text { melhores opçø̃es para a } \\
\text { própria vida. } \\
\text { cobrança dos filhos: no } \\
\text { contexto, julgamento } \\
\text { dos filhos pela atitude } \\
\text { de denunciar seu pai. }\end{array}$ & $\begin{array}{l}\text { A denúncia foi feita por não } \\
\text { haver outro recurso para } \\
\text { defender-se das agressões do } \\
\text { marido, quando apenas exercia } \\
\text { seu direito de fazer suas } \\
\text { escolhas. }\end{array}$ & $\begin{array}{l}\text { 9.6 A violência é desencadeada quando } \\
\text { o marido não consegue impor sua } \\
\text { vontade. }\end{array}$ \\
\hline
\end{tabular}




\begin{tabular}{|c|c|c|c|}
\hline $\begin{array}{l}\text { Unidades de significado } \\
\text { (linguagem do participante) }\end{array}$ & $\begin{array}{l}\text { Primeiras } \\
\text { Elucidações }\end{array}$ & $\begin{array}{l}\text { Linguagem do } \\
\text { Pesquisador }\end{array}$ & $\begin{array}{l}\text { Unidades de Significado } \\
\text { (enfoque no fenômeno interrogado) }\end{array}$ \\
\hline $\begin{array}{l}\text { demonstra que gosta muito de mim, que não aceita por } \\
\text { este amor, que é um amor doentio, e...como ele está } \\
\text { muito doente, eu não quero que meus filhos cobrem de } \\
\text { mim futuramente se acontecer alguma coisa. } \\
\text { 8. Então, vou dar uma nova oportunidade, mas eu não } \\
\text { vou sofrer violência de novo. }\end{array}$ & & $\begin{array}{l}\text { A participante resolveu voltar } \\
\text { par o marido, mas não está } \\
\text { disposta a sofrer novas } \\
\text { agressões. }\end{array}$ & $\begin{array}{l}\text { 9.7 A mulher desiste da denúncia por } \\
\text { temer julgamentos futuros dos filhos. } \\
\begin{array}{l}9.8 \text { A mulher condiciona a } \\
\text { reconciliação à cessação da violência. }\end{array}\end{array}$ \\
\hline
\end{tabular}




\section{DEPOIMENTO 9}

\section{ARTICULAÇÃO DAS IDÉIAS PELA PESQUISADORA}

A participante foi agredida ao tentar separar-se, após 11 anos de casamento. Relata sua tristeza e dificuldade em denunciar o pai de seu filho. $\mathrm{O}$ marido está doente e arrependeu-se da agressão.

Fez uma denúncia anteriormente, que não foi adiante, não entende por quê. Os comportamentos agressivos aconteceram verbal e fisicamente, diante do filho e no seu trabalho. A denúncia foi feita para mostrar-lhe que ele não pode desrespeitá-la. A desistência deve-se ao estado de saúde do marido, que tem uma doença grave; e ao temor de ser julgada pelo filho como responsável por prejudicá-lo.

Mostra-se ambígua ao afirmar os seus direitos, fazendo a denúncia, e ao retirá-la, como se desistisse deles, pelo temor das conseqüências da denúncia para o marido. 


\section{Depoimento 10}

A minha experiência com o espancamento foi complicado, porque a gente tava brigando e de repente ele começou a me espancar e eu peguei a minha menina, eu tenho uma filha com ele. Ele começou a me espancar eu com a menina no colo. Então tudo aquilo que você cria, num casamento, acaba naquele momento e eu pra vim denunciar, foi complicado também, porque eu fiquei naquela dúvida, tem a menina, a gente tinha uma vida junto, eu gosto dele, entendeu? Mas, ham .. mas eu peguei vim denunciar, mas ai ele começou a pedir uma chance a minha menina começou a ficar doente também, e como eu já disse eu gosto dele, eu resolvi dar mais uma chance, porque eu acho que todo mundo tem direito a mais uma chance né. Então por isso que eu tirei o processo, a retirada do processo, mas a mágoa sempre vai ficar, não tem como. Sempre vai ficar essa mágoa e vira e mexe, dependendo do que ele faz a gente volta a lembrar, isso nunca mais eu vou esquecer, então a gente sempre vais ficar meio com um pé atrás. Mas, tamo indo. Tamo levando, depois que eu tirei o processo ele não me agrediu mais, pelo menos até agora, a gente não, nem discussão direito não ta tendo, entendeu e a gente ta tentando seguir o ritmo e levar as coisas, porque a gente tem uma criança pequena também e acho que a gente tem que lutar por essa criança também, entendeu, não é só por no mundo e deixar ela lá e começar com briga, pra criança vê também. Então aí a gente ta levando, tamo fazendo o que dá. Eu só acho que se aconteceu alguma coisa se algumas mulheres sofre agressão, eu acho que elas deve denunciar, principalmente se foi mais de uma vez, no meu caso foi uma vez, mas tem muita gente que fica anos nisso, então, eu acho que deve denunciar sim, porque é um direito e elas tem que denunciar, não pode deixar assim não. Só isso. 


\section{DEPOIMENTO 10}

ANÁLISE IDEOGRÁFICA

\begin{tabular}{|c|c|c|c|}
\hline $\begin{array}{l}\text { Unidades de significado } \\
\text { (linguagem do participante) }\end{array}$ & $\begin{array}{c}\text { Primeiras } \\
\text { Elucidações }\end{array}$ & $\begin{array}{l}\text { Linguagem do } \\
\text { Pesquisador }\end{array}$ & $\begin{array}{l}\text { Unidades de Significado } \\
\text { (enfoque no fenômeno interrogado) }\end{array}$ \\
\hline $\begin{array}{l}\text { 1. A minha experiência com o espancamento foi } \\
\text { complicado, porque a gente tava brigando e de repente } \\
\text { ele começou a me espancar, } \\
\text { 2. ...e eu peguei a minha menina, eu tenho uma filha } \\
\text { com ele. Ele começou a me espancar, eu com a menina } \\
\text { no colo. } \\
\text { 2. Então, tudo aquilo que você cria num casamento } \\
\text { acaba naquele momento, e eu pra vim denunciar. } \\
\text { 3. Foi complicado, também, porque eu fiquei naquela } \\
\text { dúvida, tem a menina, a gente tinha uma vida junto, eu } \\
\text { gosto dele, entendeu? } \\
\text { 4. Mas, ahm...mas eu peguei, vim denunciar, mas aí ele } \\
\text { começou a pedir uma chance. A minha menina } \\
\text { começou a ficar doente também e, como eu já disse, eu } \\
\text { gosto dele, eu resolvi dar mais uma chance, porque eu } \\
\text { acho que todo mundo tem direito a mais uma chance. } \\
\text { 5. Então por isso que eu tirei o processo, a retirada do } \\
\text { processo, mas a mágoa sempre vai ficar, não tem } \\
\text { como. Sempre vai ficar essa mágoa e vira e mexe, }\end{array}$ & $\begin{array}{l}\text { crer: supor, julgar; ter } \\
\text { fé ou crença, julgar } \\
\text { como verdadeiro. }\end{array}$ & $\begin{array}{l}\text { A participante discutia com o } \\
\text { marido, que começou a espancá- } \\
\text { la. } \\
\text { Sendo espancada, a participante } \\
\text { pegou a filha no colo, e o marido } \\
\text { continuou a agressão. } \\
\text { A participante passou a } \\
\text { desconsiderar o casamento e } \\
\text { denunciou-o. } \\
\text { A participante tinha dúvidas } \\
\text { sobre a atitude de denunciar o } \\
\text { marido, a quem esta ligada } \\
\text { afetivamente. } \\
\text { Após a denúncia e da filha } \\
\text { doente, resolveu dar-lhe nova } \\
\text { oportunidade. }\end{array}$ & $\begin{array}{l}\text { 10.1 A violência entre o casal envolve } \\
\text { os filhos. } \\
10.2 \text { A agressão torna o casamento } \\
\text { questionável, pois denuncia-se o } \\
\text { companheiro como inimigo. } \\
\text { 10.3 A mulher sente-se insegura ao } \\
\text { denunciar o companheiro. } \\
10.4 \text { Após a denúncia, o afeto pelo } \\
\text { marido agressor leva à reconciliação. }\end{array}$ \\
\hline
\end{tabular}




\begin{tabular}{|c|c|c|c|}
\hline $\begin{array}{l}\text { Unidades de significado } \\
\text { (linguagem do participante) }\end{array}$ & $\begin{array}{c}\text { Primeiras } \\
\text { Elucidaçס̄es }\end{array}$ & $\begin{array}{l}\text { Linguagem do } \\
\text { Pesquisador }\end{array}$ & $\begin{array}{c}\text { Unidades de Significado } \\
\text { (enfoque no fenômeno interrogado) }\end{array}$ \\
\hline $\begin{array}{l}\text { dependendo do que ele faz a gente volta a lembrar, isso } \\
\text { nunca mais eu vou esquecer, então a gente sempre vais } \\
\text { ficar meio com um pé atrás. } \\
\text { 6. Mas, tamos indo, tamos levando. Depois que eu tirei } \\
\text { o processo, ele não me agrediu mais, pelo menos até } \\
\text { agora. A gente não, nem discussão direito não tá tendo, } \\
\text { entendeu? e a gente tá tentando seguir o ritmo e levar } \\
\text { as coisas, } \\
\text { 7. ... porque a gente tem uma criança pequena também } \\
\text { e acho que a gente tem que lutar por essa criança } \\
\text { também, entendeu? Não é só pôr no mundo e deixar ela } \\
\text { lá e começar com briga, a criança vê também. Então aí } \\
\text { a gente tá levando, tamos fazendo o que dá. } \\
\text { 8. Eu só acho que se aconteceu alguma coisa, se } \\
\text { algumas mulheres sofrem agressão, eu acho que elas } \\
\text { devem denunciar, principalmente se foi mais de uma } \\
\text { vez. } \\
\text { 9. No meu caso foi uma vez, mas tem muita gente que } \\
\text { fica anos nisso, então eu acho que deve denunciar sim, } \\
\text { porque é um direito e elas tem que denunciar, não pode }\end{array}$ & 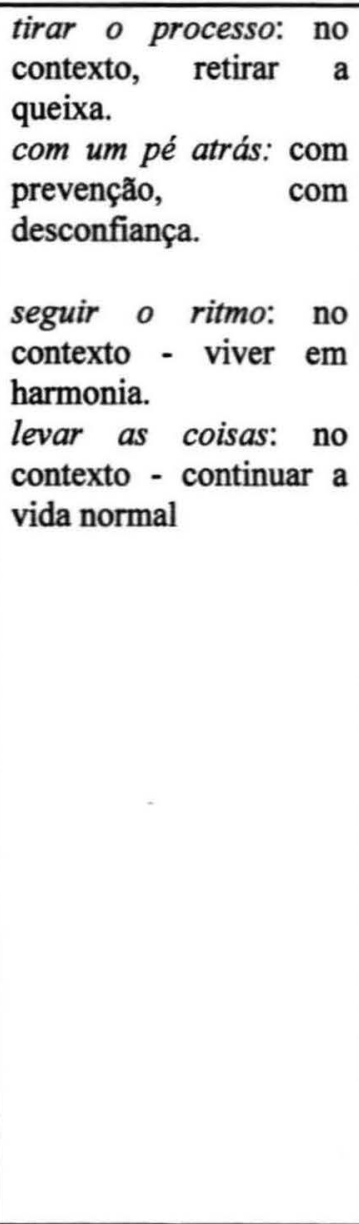 & $\begin{array}{l}\text { Depois da retirada da queixa, o } \\
\text { marido não a agrediu e nem } \\
\text { discute, procuram continuar a } \\
\text { vida normal. }\end{array}$ & $\begin{array}{l}\text { 10.7 As mulheres devem denunciar a } \\
\text { agressão sofrida, sempre. } \\
\begin{array}{l}10.7 \text { É direito legal das mulheres } \\
\text { proteger-se da agressão do } \\
\text { companheiro. }\end{array}\end{array}$ \\
\hline
\end{tabular}




\begin{tabular}{|l|c|c|c|}
\hline $\begin{array}{c}\text { Unidades de significado } \\
\text { (linguagem do participante) }\end{array}$ & $\begin{array}{c}\text { Primeiras } \\
\text { Elucidações }\end{array}$ & $\begin{array}{c}\text { Linguagem do } \\
\text { Pesquisador }\end{array}$ & $\begin{array}{c}\text { Unidades de Significado } \\
\text { (enfoque no fenômeno interrogado) }\end{array}$ \\
\hline deixar assim não. & & & \\
\hline
\end{tabular}




\section{DEPOIMENTO 10}

\section{ARTICULAÇÃO DAS IDÉIAS PELA PESQUISADORA}

O marido iniciou a agressão física e a continuou, mesmo quando a participante pegou a sua filha no colo, segundo ela. Isto fê-la desacreditar da confiança na união do casal, portanto, no companheiro.

Após a denúncia, o marido pediu outra oportunidade para viver com ela, o que a levou a retirar a denúncia. Atualmente esforçam-se, ela e o companheiro, a viver bem, embora ela se sinta magoada e temerosa de novas agressões. Manter o casamento, para ela, significa cuidar e educar a filha.

Avalia que a mulher agredida deve apresentar denúncia contra a agressão, sempre: uma afirmação ambígua, uma vez que a participante não levou a sua denúncia adiante. 


\section{Depoimento 11}

Foi horrível, eu sempre fui agredida, desde que eu me casei. Ai separei; comecei o relacionamento com ele há 10 anos e há 10 anos sou agredida violentamente mesmo. Agora ainda não, mas antes ele me batia tanto, assim no rosto e chegava a sair faísca pelo meus olhos eu via estrelinhas, faísca mesmo, sumir meus sentidos, eu já fui quebrada, quebrava minha costela, quebrava meu dedo, chutava, espancava, jogada na rua, feito uma cadela, sabe, mais aí, como eu nunca tive pra onde ir, sempre o que eu ganho é pouco; que eu trabalho como limpeza, meu salário é de 275 reais eu tenho uma filha, o pai não dá pensão eu não tenho meio de sobrevivência, eu sei isto não é desculpa pra ficar com ele, se eu estou com ele porque algum sentimento ainda devo ter por ele. E em questão desta agressão que houve agora neste final de semana porque ele só é agressivo quando bebe, quando ele não bebe ele é uma outra pessoa, e este final de semana que houve esta agressão, foi num domingo de Páscoa ele bebeu domingo todinho, eu fiquei sozinha o dia todo dentro de casa, aí ele chegou bêbado, trocou de roupa, pegou a moto, ai perguntei se ia sair, aí ele desceu da moto, veio me espancando, me jogou com a cabeça no trinco do vitrô, que até ta fundo a minha cabeça aqui, ele me jogou na rua com minha filha, tive que dormir fora de casa, e, na segunda-feira vim aqui, só que na terça-feira ele já veio, nem falou pessoalmente, deixou uma carta, eu tenho a carta, pedindo perdão, pedindo desculpa, que não era justo eu sair da casa que a gente precisava conversar, aí nós conversamos, jurou, prometeu, que não ia beber mais, ai eu falei que tinha feito boletim de ocorrência, que ele tinha que vir aqui, tem um boletim desde de outubro que ele não compareceu, foi este boletim que foi arquivado e que, que vai subir no Fórum 2, só que na verdade, aqui na delegacia eu desistir, só que no Fórum eu vou dar este prazo de três meses a ele, pra ver se ele muda realmente, porque eu acho que quem não mudou há dez anos, não vai mudar mais, eu acho, eu sei que vou ser agredida por ele, então é isto aí, só que a experiência é horrível e tem as ameaças, porque a gente vem aqui, faz o boletim de ocorrência, mandam chamar eles quando você chega em casa, você é agredida novamente, você torna vir, faz outro, chega, você não tem proteção da policia 24 horas, então o que ele falou pra mim, o pouco que ele me ameaça, eu tenho três filhos, não com ele, com o outro, com o primeiro casamento, então, me ameaça assim, se eu vir na justiça, ele, se tirar ele da casa, ele mata minha mãe e meus filhos, e são as coisas que eu tenho na vida, eu não tenho mais nada, então, você fica naquele medo, então ele bêbado, ele é capaz de matar sim, ele faz qualquer coisa bêbado; então, eu fico assim, a minha vida corre risco junto com ele e sem ele. De qualquer jeito eu estou correndo risco de vida. Nesse dia 
que ele me agrediu ele pegou faca, ele amolou as duas facas, veio pra cima de mim, eu tive que correr, sair com a menina de dentro de casa, então como é que fica a cabeça da minha filha, fica a minha cabeça e a cabeça da minha filha, eu tenho problema de depressão, estou afastada do serviço por depressão, porque tenho um sobrinho que se matou no trinco da porta, se enforcou foi demorado, eu presenciei esta cena, ele foi criado junto comigo, hoje está fazendo dois anos, eu passei ele, e tudo isso então, e eu não consigo tomar atitude, eu não consigo me liberar deste choque que eu tive, e eu não consigo me separar dele, eu não tenho como viver sozinha, eu não tenho ninguém, eu só tenho a menina de 14 anos e eu. E só o que eu ganho que não dá para pagar o aluguel e não dá para sustentar ela, não dá pra nada. O que eu tenho a dizer é isto. 


\section{DEPOIMENTO 11 \\ ANÁLISE IDEOGRÁFICA}

\begin{tabular}{|c|c|c|c|}
\hline $\begin{array}{l}\text { Unidades de significado } \\
\text { (linguagem do participante) }\end{array}$ & $\begin{array}{l}\text { Primeiras } \\
\text { Elucidações }\end{array}$ & $\begin{array}{l}\text { Linguagem do } \\
\text { Pesquisador }\end{array}$ & $\begin{array}{l}\text { Unidades de Significado } \\
\text { (enfoque no fenômeno interrogado) }\end{array}$ \\
\hline $\begin{array}{l}\text { 1. Foi horrível, eu sempre fui agredida, desde que eu } \\
\text { me casei. Aí me separei; comecei o relacionamento } \\
\text { com ele há } 10 \text { anos e há } 10 \text { anos sou agredida } \\
\text { violentamente mesmo. } \\
\text { 2. Agora ainda não, mas antes ele me batia tanto, assim } \\
\text { no rosto e chegava a sair faísca pelo meus olhos, eu via } \\
\text { estrelinhas, faísca mesmo... sumir meus sentidos. Eu já } \\
\text { fui quebrada, quebrava minha costela, quebrava meu } \\
\text { dedo, chutava, espancava... jogada na rua, feito uma } \\
\text { cadela, sabe? } \\
\text { 3. Mas aí, como eu nunca tive pra onde ir, sempre o } \\
\text { que eu ganho é pouco; que eu trabalho como limpeza, } \\
\text { meu salário é de } 275 \text { reais, eu tenho uma filha, o pai } \\
\text { não dá pensão...Eu não tenho meio de sobrevivência, } \\
\text { eu sei que isto não é desculpa pra ficar com ele, se eu } \\
\text { estou com ele porque algum sentimento ainda devo ter } \\
\text { por ele... } \\
4 \text {. E em questão desta agressão, que houve agora neste } \\
\text { final de semana, porque ele só é agressivo quando }\end{array}$ & $\begin{array}{l}\text { Segundo o Código } \\
\text { Penal Brasileiro - artigo } \\
129 \text {, parágrafo } 90 \text { - } \\
\text { (Nucci, 2003) a mulher } \\
\text { que sofre uma lesão } \\
\text { corporal denuncia o } \\
\text { agressor. Se a lesão for } \\
\text { considerada leve, pelos } \\
\text { médicos legistas, a } \\
\text { vítima terá seis meses } \\
\text { para oferecer represen- } \\
\text { tação à justiça. Se a } \\
\text { lesão for considerada } \\
\text { grave, a aço do } \\
\text { Ministério Público é } \\
\text { imediata, não depende } \\
\text { da iniciativa da } \\
\text { ofendida. }\end{array}$ & $\begin{array}{l}\text { A participante tem sido agredida } \\
\text { neste casamento, assim como foi } \\
\text { no anterior. } \\
\text { Já foi mais agredida do que hoje, } \\
\text { pelo atual marido, } \\
\text { violentamente, resultando em } \\
\text { lesões graves. }\end{array}$ & $\begin{array}{l}11.1 \text { A agressão pelo marido é } \\
\text { freqüente e violenta. }\end{array}$ \\
\hline
\end{tabular}




\begin{tabular}{|c|c|c|c|}
\hline $\begin{array}{l}\text { Unidades de significado } \\
\text { (linguagem do participante) }\end{array}$ & $\begin{array}{l}\text { eiras } \\
\text { lações }\end{array}$ & $\begin{array}{l}\text { Linguagem do } \\
\text { Pesquisador }\end{array}$ & $\begin{array}{c}\text { Unidades de Significado } \\
\text { (enfoque no fenômeno interrogado) }\end{array}$ \\
\hline $\begin{array}{l}\text { bebe, quando ele não bebe ele é uma outra pessoa, e } \\
\text { este final de semana que houve esta agressão, foi num } \\
\text { domingo de Páscoa: ele bebeu domingo todinho, eu } \\
\text { fiquei sozinha o dia todo dentro de casa, aí ele chegou } \\
\text { bêbado, trocou de roupa, pegou a moto, aí perguntei se } \\
\text { ia sair, aí ele desceu da moto, veio me espancando, me } \\
\text { jogou com a cabeça no trinco do vitrô, que até tá fundo } \\
\text { a minha cabeça aqui. Ele me jogou na rua com minha } \\
\text { filha, tive que dormir fora de casa, e, na segunda- feira } \\
\text { vim aqui. } \\
\text { 5. Só que na terça- feira ele já veio, nem falou } \\
\text { pessoalmente, deixou uma carta, eu tenho a carta, } \\
\text { pedindo perdão, pedindo desculpa, que não era justo eu } \\
\text { sair da casa, que a gente precisava conversar. } \\
\text { 6. Aí nós conversamos, jurou, prometeu, que não ia } \\
\text { beber mais, } \\
\text { 7. ... aí eu falei que tinha feito boletim de ocorrência, } \\
\text { que ele tinha que vir aqui. Tem um boletim desde de } \\
\text { outubro que ele não compareceu, foi este boletim que } \\
\text { foi arquivado e que vai subir no Fórum } 2 \text {. } \\
8 \text {. Só que, na verdade, aqui na delegacia eu desisti, só }\end{array}$ & $\begin{array}{l}\text { vai subir no Fórum: } \\
\text { após o } \mathrm{BO} \text {, o exame de } \\
\text { corpo de delito, se a }\end{array}$ & $\begin{array}{l}\text { No dia seguinte à denúncia, ele } \\
\text { deixou uma carta pedindo } \\
\text { perdão e pedindo para } \\
\text { dialogarem. } \\
\text { O marido jurou não beber mais. } \\
\text { A participante lhe comunicou } \\
\text { sobre a formalização da queixa. } \\
\text { Ele já tem uma ocorrência de } \\
\text { agressão anterior do Fórum,a } \\
\text { cuja convocação não }\end{array}$ & $\begin{array}{l}11.4 \text { Após a agressão, o marido } \\
\text { arrepende-se e tenta a reconciliação. } \\
11.5 \text { O agressor promete mudar o } \\
\text { comportamento } \\
11.6 \text { A tramitação da queixa na } \\
\text { Delegacia é demorada e } \\
\text { os efeitos da queixa são retardados. }\end{array}$ \\
\hline
\end{tabular}




\begin{tabular}{|c|c|c|c|}
\hline $\begin{array}{l}\text { Unidades de significado } \\
\text { (linguagem do participante) }\end{array}$ & $\begin{array}{c}\text { Primeiras } \\
\text { Elucidações }\end{array}$ & $\begin{array}{l}\text { Linguagem do } \\
\text { Pesquisador }\end{array}$ & $\begin{array}{c}\text { Unidades de Significado } \\
\text { (enfoque no fenômeno interrogado) }\end{array}$ \\
\hline $\begin{array}{l}\text { que no Fórum eu vou dar este prazo de três meses a ele, } \\
\text { pra ver se ele muda realmente; porque eu acho que } \\
\text { quem não mudou há dez anos, não vai mudar mais, eu } \\
\text { acho. } \\
\text { 9. Eu sei que vou ser agredida por ele, então é isto á, } \\
\text { só que a experiência é horrível. } \\
\text { 10. E tem as ameaças, porque a gente vem aqui, faz o } \\
\text { boletim de ocorrência, mandam chamar eles, quando } \\
\text { você chega em casa, você é agredida novamente. Você } \\
\text { torna vir, faz outro, chega, você não tem proteção da } \\
\text { polícia } 24 \text { horas. } \\
\text { 11. Então o que ele falou pra mim, o pouco que ele me } \\
\text { ameaça, eu tenho três filhos, não com ele, com o outro, } \\
\text { com o primeiro casamento, então, me ameaça assim, se } \\
\text { eu vir na justiça, se tirar ele da casa, ele mata minha } \\
\text { mãe e meus filhos, e são as coisas que eu tenho na vida, } \\
\text { eu não tenho mais nada... } \\
\text { 12. Então, você fica naquele medo, então ele bêbado, } \\
\text { ele é capaz de matar sim, ele faz qualquer coisa } \\
\text { bêbado. Então, eu fico assim, a minha vida corre risco } \\
\text { junto com ele e sem ele. De qualquer jeito, eu estou }\end{array}$ & $\begin{array}{l}\text { mulher não desiste da } \\
\text { denúncia, ocorre o } \\
\text { 'procedimento junto ao } \\
\text { Forum', com o } \\
\text { encaminhamento para } \\
\text { propositura de 'Ação } \\
\text { cautelar de Afastamento } \\
\text { do Cônjuge' e } \\
\text { Separação Judicial. } \\
\text { (Nucci, 2003) }\end{array}$ & $\begin{array}{l}\text { A participante espera novas } \\
\text { agressões. } \\
\text { A participante considera que a } \\
\text { ação da Delegacia não lhe } \\
\text { oferece proteção contra o } \\
\text { marido. } \\
\text { Embora o marido tenha feito } \\
\text { promessas de mudar, ele } \\
\text { representa uma ameaça } \\
\text { constante contra ela e os filhos e } \\
\text { ela teme represálias se fizer } \\
\text { queixa contra ele. } \\
\text { A participante sente que corre } \\
\text { risco de vida, esteja ao lado do } \\
\text { marido ou abandonando-o. }\end{array}$ & $\begin{array}{l}\text { 11.7 A mulher agredida espera que a } \\
\text { queixa formalizada reprima os } \\
\text { comportamentos agressivos do } \\
\text { companheiro. } \\
11.8 \text { A mulher agredida pelo marido } \\
\text { tem consciência de que agressão se } \\
\text { repetirá. } \\
11.9 \text { A proteção legal contra o marido } \\
\text { agressor é limitada. }\end{array}$ \\
\hline
\end{tabular}




\begin{tabular}{|c|c|c|c|}
\hline $\begin{array}{l}\text { Unidades de significado } \\
\text { (linguagem do participante) }\end{array}$ & $\begin{array}{c}\text { Primeiras } \\
\text { Elucidações }\end{array}$ & $\begin{array}{l}\text { Linguagem do } \\
\text { Pesquisador }\end{array}$ & $\begin{array}{l}\text { Unidades de Significado } \\
\text { (enfoque no fenômeno interrogado) }\end{array}$ \\
\hline $\begin{array}{l}\text { correndo risco de vida. } \\
\text { 13. Nesse dia que ele me agrediu, ele pegou faca, ele } \\
\text { amolou as duas facas, veio pra cima de mim, eu tive } \\
\text { que correr, sair com a menina de dentro de casa. Então } \\
\text { como é que fica a cabeça da minha filha, fica a minha } \\
\text { cabeça e a cabeça da minha filha? } \\
\text { 14. Eu tenho problema de depressão, estou afastada do } \\
\text { serviço por depressão, porque tenho um sobrinho que } \\
\text { se matou no trinco da porta, se enforcou. Foi } \\
\text { demorado, eu presenciei esta cena, ele foi criado junto } \\
\text { comigo, hoje está fazendo dois anos...e tudo isso } \\
\text { então... e eu não consigo tomar atitude, eu não consigo } \\
\text { me liberar deste choque que eu tive, e eu não consigo } \\
\text { me separar dele. } \\
\text { 15. Eu não tenho como viver sozinha, eu não tenho } \\
\text { ninguém, eu só tenho a menina de } 14 \text { anos e eu. E só o } \\
\text { que eu ganho que não dá para pagar o aluguel e não dá } \\
\text { para sustentar ela, não dá pra nada. O que eu tenho a } \\
\text { dizer é isto. }\end{array}$ & & $\begin{array}{l}\text { A participante foi agredida } \\
\text { violentamente, sua filha } \\
\text { participando da situação. } \\
\text { A participante sofre de } \\
\text { depressão devido a situações } \\
\text { vividas com a família e não } \\
\text { consegue superá-la e tomar } \\
\text { atitudes para defender-se do } \\
\text { marido. } \\
\text { A participante vive um conflito } \\
\text { entre duas opções de vida, } \\
\text { ambas inviáveis, segundo ela. }\end{array}$ & $\begin{array}{l}11.11 \text { Os filhos são envolvidos nas } \\
\text { situações de agressão à mulher. } \\
11.12 \text { A mulher agredida sente-se } \\
\text { abalada e frágil, in capaz da reagir às } \\
\text { agressões do companheiro. }\end{array}$ \\
\hline
\end{tabular}




\section{DEPOIMENTO 11}

\section{ARTICULAÇÃo dAS IDÉIAS PELA PESQUISADORA}

A participante relata sua experiência de agressão pelo marido que dura 10 anos, desde que se casou. Relata situação similar no primeiro casamento. Descreve episódios de agressão violenta, resultando em danos físicos graves: fraturas, desmaios.Trabalha, mas ganha mal; tem filha de outro casamento e não consegue manter-se sozinha. Este é o motivo para continuar junto ao agressor, embora afirme que tem ainda afetividade por ele.

A agressão acontece sob o efeito do álcool: ele se torna violento, machuca-a e joga-a para fora de casa. No dia seguinte, desculpa-se. A participante desistiu desta última queixa, mas há uma intimação anterior, que ela mantém, como uma ameaça caso ele a agrida novamente.

Ela se sente desprotegida, ameaçada e deprimida e narra uma cena de suicídio de um sobrinho, que a deixou transtornada.

Avalia que a polícia não consegue protegê-la e o marido pode matá-la a qualquer momento. Preocupa-se com a filha, que compartilha da situação de violência. Não vê perspectivas para o seu futuro, nenhuma opção para superar o sofrimento que vivencia. 


\section{Depoimento 12}

Eu nunca tinha passado por isso, então foi assim, uma experiência muito traumatizante. Na hora, como era, como foi a primeira vez, que da agressão, então eu fiquei sem saber o que fazer. Depois como eu não queria continuar com ele, porque eu não queria continuar com uma pessoa, que é meu marido e que me agrediu e que a gente já estava em processo de separação, então eu peguei e fiz a denúncia. E, para fazer a denúncia, eu acho que foi ainda mais dificil, porque oito anos junto com a pessoa e você não conhecer a pessoa, então fica assim, bem marcante. Chorei, tal, mas consegui fazer. Sabe, já faz quase um mês praticamente desse ato, ele não fez mais nada, e nunca mais e nem dirigiu mais a palavra para mim então está tudo quieto, eu não acho justo também levar adiante uma coisa. Foi um fato isolado, não sei se teria sido isolado, mas, no momento é isto que eu penso. Tenho duas filhas, uma de 14 anos, que viu,e uma pequenininha de três anos. E agora nós estamos separados, ele tá morando com a mãe dele e eu morando com as duas. Levo elas todo final de semanas mesmo durante a semana, que nem hoje eu levei elas pra ficar com ele, ele fica numa boa. Não converso com ele, mas a gente está assim aparentemente se entendendo. Porque, não temos brigado, não temos nada. Ai eu desisti, porque eu não quero prejudicar ninguém, eu acho que se eu mantivesse isso eu estaria prejudicando, por que no fundo, no fundo, eu recuso a crer que ele é uma pessoa tão maldosa e afinal de contas ele só deu um tapa em mim. Se fosse uma coisa grave, tá bem, tá certo que um tapa é um tapa, é uma agressão, que nem eu falei pro juiz, pro delegado. Mas é por causa disso, por conta disso, pois foi apenas um tapa e eu quero desculpar, achando o tapa foi acidental, digamos assim. A única coisa que eu quero que não aconteça mais, para que eu tenha essa conviç̧ão do que eu fiz está certo. 


\section{DEPOIMENTO 12}

ANÁLISE IDEOGRÁFICA

\begin{tabular}{|c|c|c|c|}
\hline $\begin{array}{c}\text { Unidades de significado } \\
\text { (linguagem do participante) }\end{array}$ & $\begin{array}{c}\text { Primeiras } \\
\text { Elucidações }\end{array}$ & $\begin{array}{r}\text { Lingu } \\
\text { Pesg } \\
\end{array}$ & $\begin{array}{c}\text { Unidades de Significado } \\
\text { (enfoque no fenômeno interrogado) }\end{array}$ \\
\hline $\begin{array}{l}\text { 1. Eu nunca tinha passado por isso, então foi assim, uma } \\
\text { experiência muito traumatizante. } \\
\text { 2. Na hora, como era, como foi a primeira vez, então eu } \\
\text { fiquei sem saber o que fazer. } \\
\text { 3. Depois como eu não queria continuar com ele, porque } \\
\text { eu não queria continuar com uma pessoa, que é meu } \\
\text { marido e que me agrediu e que a gente já estava em } \\
\text { processo de separação, então eu peguei e fiz a denúncia } \\
\text { 4. E, para fazer a denúncia, eu acho que foi ainda mais } \\
\text { difícil, porque oito anos junto com a pessoa e você não } \\
\text { conhecer a pessoa, então fica assim, bem marcante. } \\
\text { Chorei, tal, mas consegui fazer. } \\
\text { 5. Sabe, já faz quase um mês praticamente desse ato, ele } \\
\text { não fez mais nada, e nunca mais e nem dirigiu mais a } \\
\text { palavra para mim então está tudo quieto, eu não acho justo } \\
\text { também levar adiante. } \\
\text { 6. Foi um fato isolado, não sei se teria sido isolado, mas, } \\
\text { no momento é o que penso. } \\
\text { 7. Tenho duas filhas, uma de } 14 \text { anos, que viu, e uma } \\
\text { pequenininha de três anos. E agora nós estamos separados, }\end{array}$ & $\begin{array}{l}\text { levar adiante: no } \\
\text { contexto, continuar o } \\
\text { processo contra } \\
\text { marido. } \\
\text { fato isolado: no } \\
\text { contexto - fato sem } \\
\text { significado, incidente. }\end{array}$ & $\begin{array}{l}\text { Esta foi a primeira agressão } \\
\text { por parte do marido e } \\
\text { chocou-a. } \\
\text { A situação inesperada } \\
\text { deixou-a sem reação. } \\
\text { Desejando separar-se do } \\
\text { marido, fez a denúncia } \\
\text { contra ele. } \\
\text { Foi difícil e doloroso fazer a } \\
\text { denúncia contra o marido, } \\
\text { que lhe mostrou uma face } \\
\text { desconhecida. } \\
\text { Depois de um mês da } \\
\text { agressão, não teve mais } \\
\text { contato com o marido e } \\
\text { considera injusto manter a } \\
\text { denúncia contra ele. } \\
\text { A agressão foi apenas um } \\
\text { incidente. } \\
\text { O casal está separado, tem } \\
\text { duas filhas, que estão com a } \\
\text { participante. } \\
\text { O marido tem horários para }\end{array}$ & $\begin{array}{l}12.5 \text { Quando os sentimentos que } \\
\text { levaram a denunciar o agressor são } \\
\text { amenizados, a vítima reconsidera sua } \\
\text { decisão de formalizar a queixa. }\end{array}$ \\
\hline
\end{tabular}




\begin{tabular}{|c|c|c|c|}
\hline $\begin{array}{l}\text { Unidades de significado } \\
\text { (linguagem do participante) }\end{array}$ & $\begin{array}{c}\text { Primeiras } \\
\text { Elucidações }\end{array}$ & $\begin{array}{l}\text { Linguagem do } \\
\text { Pesquisador }\end{array}$ & $\begin{array}{c}\text { Unidades de Significado } \\
\text { (enfogue no fenômeno interrogado) }\end{array}$ \\
\hline $\begin{array}{l}\text { ele tá morando com a mãe dele e eu morando com as duas. } \\
\text { 8. Levo elas todo final de semanas mesmo durante a } \\
\text { semana, que nem hoje eu levei elas pra ficar com ele, ele } \\
\text { fica numa boa. } \\
\text { 9. Não converso com ele, mas a gente está assim } \\
\text { aparentemente se entendendo. Porque, não temos brigado, } \\
\text { não temos nada. } \\
\text { 10. Aí eu desisti, porque eu não quero prejudicar ninguém, } \\
\text { eu acho que se eu mantivesse isso eu estaria } \\
\text { prejudicando, } \\
\text { 11.... por que no fundo, no fundo, eu recuso a crer que ele } \\
\text { é uma pessoa tão maldosa e afinal de contas ele só deu um } \\
\text { tapa em mim. } \\
\text { 12. Se fosse uma coisa grave, tá bem, tá certo que um tapa } \\
\text { é um tapa, né, é uma agressão, que nem eu falei pro juiz, } \\
\text { pro delegado, né, } \\
\text { 13... mas é por causa disso, por conta disso, pois foi apenas } \\
\text { um tapa e eu quero desculpar, achando o tapa foi acidental, } \\
\text { digamos assim. } \\
\text { 14. A única coisa que eu quero que não aconteça mais, } \\
\text { 15..para que eu tenha essa convicção do que eu fiz está } \\
\text { certo. }\end{array}$ & $\begin{array}{l}\text { prejudicar: causar } \\
\text { danos, lesar, causar } \\
\text { transtornos. } \\
\text { maldosa: que denota } \\
\text { maldade, perverso. } \\
\text { tapa:pancada com a } \\
\text { mão. } \\
\text { agressão: investida, } \\
\text { ataque, ofensa, insulto. }\end{array}$ & $\begin{array}{l}\text { Considera que um tapa é uma } \\
\text { agressão, como afirmou para } \\
\text { o juiz e para o delegado. } \\
\text { Sendo apenas um tapa, } \\
\text { deseja desculpá-lo. } \\
\text { Deseja apenas que a agressão } \\
\text { não se repita. } \\
\text { Precisa da acreditar que fez o } \\
\text { certo. }\end{array}$ & 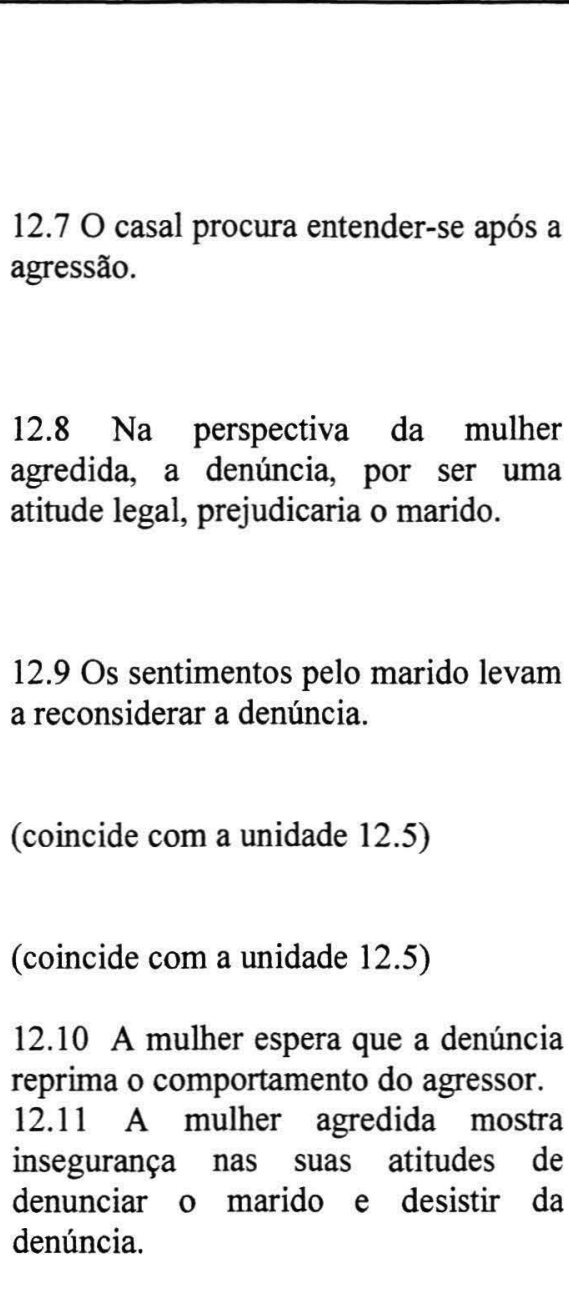 \\
\hline
\end{tabular}




\section{DEPOIMENTO 12 \\ ARTICULAÇÃO DAS IDÉIAS PELA PESQUISADORA}

A participante descreve um casamento já deteriorado, antes da agressão. A denúncia foi resultado de sua indignação após a agressão sofrida. Contraditoriamente, em alguns momentos do seu relato, ela minimiza a agressão, descrevendo-o como "apenas um tapa". Mostra-se ambígüa, ao afirmar, em alguns momentos, que o evento teria sido acidental. Fica a pergunta: por que então a denúncia?

Sobre a desistência, justifica-a pelas boas qualidades do agressor e pela intenção de continuar uma relação de amizade por causa das filhas, mesmo não estando juntos. 
ANÁLISE NOMOTÉTICA: Temas que emergiram das convergências de todos os depoimentos

\begin{tabular}{|c|c|c|c|c|c|c|c|c|c|c|c|c|c|}
\hline Temas & Convergências & P1 & P2 & P3 & P4 & P5 & P6 & P7 & P8 & P9 & P10 & P11 & P12 \\
\hline \multirow{4}{*}{$\begin{array}{l}\text { 1. Denúncia e } \\
\text { Desistência }\end{array}$} & O conflito & 1.9 & 2.2 & 3.12 & 4.4 & 5.5 & 6.1 & 7.1 & $\begin{array}{l}8.1 \\
8.2\end{array}$ & $\begin{array}{l}9.1 \\
9.5\end{array}$ & 10.2 & $\begin{array}{l}11.1 \\
11.4\end{array}$ & $\begin{array}{l}12.1 \\
12.4\end{array}$ \\
\hline & A denúncia de agressão & 1.8 & 2.4 & 3.5 & 4.1 & 5.2 & 6.1 & 7.2 & 8.2 & 9.7 & 10.4 & 11.4 & 12.3 \\
\hline & Depois da denúncia & \begin{tabular}{|l|}
1.4 \\
1.11 \\
\end{tabular} & 2.3 & 3.10 & 4.8 & 5.7 & 6.6 & 7.3 & 8.6 & 9.3 & 10.4 & 11.3 & 12.6 \\
\hline & Desistindo da denúncia & \begin{tabular}{|l|}
1.2 \\
1.6 \\
\end{tabular} & 2,9 & 3.7 & 4.8 & & 6.4 & 7.4 & 8.6 & & 1.5 & 11.3 & 12.6 \\
\hline \multirow{3}{*}{$\begin{array}{l}\text { 2. Relacionamento } \\
\text { com as pessoas }\end{array}$} & $\begin{array}{l}\text { Relações com o } \\
\text { agressor }\end{array}$ & 1.10 & 2.8 & 3.14 & 4.10 & & 6.7 & & 8.6 & 9.7 & 10.3 & $\begin{array}{l}11.8 \\
11.12\end{array}$ & 12.9 \\
\hline & \begin{tabular}{|l|} 
Relações c/ familiares \\
\end{tabular} & 1.5 & 2.5 & 3.12 & & & & & 8.2 & 9.8 & 10.7 & 11.13 & 12.7 \\
\hline & Relações com DDM & & & 3.6 & 4.7 & 5.8 & 6.6 & & & & 10.6 & 11.7 & \\
\hline \multirow{4}{*}{$\begin{array}{l}\text { 3. A reflexão sobre } \\
\text { a experiência de } \\
\text { desistir da denúncia }\end{array}$} & Avaliando o acontecido & & 2.1 & 3.1 & & 5.2 & & & & 9.4 & 10.5 & 11.11 & 12.15 \\
\hline & \begin{tabular}{|l|} 
Denúncia como \\
autonomia
\end{tabular} & & & 3.9 & 4.10 & 5.6 & & & & 9.7 & 10.9 & & \\
\hline & \begin{tabular}{|l|}
$\begin{array}{l}\text { Ambigüidade ao } \\
\text { denunciar }\end{array}$ \\
\end{tabular} & 1.10 & & & 4.10 & 5.8 & 6.7 & 7.5 & 8.9 & & 10.8 & 11.15 & $\begin{array}{l}12.11 \\
12.12 \\
\end{array}$ \\
\hline & $\begin{array}{l}\text { Tentativa de manter a } \\
\text { familia }\end{array}$ & 1.6 & & 3.9 & 4.9 & & & 7.6 & 8.7 & 9.7 & & 11,12 & \\
\hline
\end{tabular}




\section{ANÁLISE E INTERPRETAÇÃO DOS DADOS}

As descrições das participantes do estudo foram analisadas e categorizadas segundo os procedimentos: a redução, a análise e a interpretação fenomenológicas, como foi, anteriormente, exposto ao apresentar-se o método do estudo.

Inicialmente, na análise individual da cada discurso - análise ideográfica identificaram-se as unidades de significado da descrição que respondiam à questão do estudo, alcançando-se a compreensão dos significados atribuídos pela participante à experiência vivida (p 25 a p 81).

Num segundo momento, buscaram-se as convergências das unidades de significado de todas as descrições - análise nomotética - que descrevem as verdades gerais sobre o fenômeno estudado (p 82).

As convergências das unidades de significado foram categorizadas segundo os seguintes subtemas:

- Denúncia e desistência

- Relacionamento com as pessoas

- A reflexão sobre a experiência vivida

Com o intuito de clarificar a interpretação dos dados, na análise das convergências dos depoimentos, que será apresentada na seqüência, serão citadas falas das participantes, como foram expressas, identificadas ao final da citação com o número do depoimento correspondente e o número da unidade de significado. 


\section{1 - Denúncia e Desistência}

Neste subtema incluem as seguintes convergências:

- O conflito doméstico

- A denúncia da agressão

- Depois da denúncia

- Desistindo da denúncia ao agressor

As mulheres descrevem, nos seus depoimentos, a sua trajetória desde a agressão sofrida até a denúncia do agressor, motivada pela humilhação e sentimento de terem sido traídas e injustiçadas, por uma pessoa à qual se ligam afetivamente e com a qual haviam assumido um compromisso de fidelidade e confiança.

"Eu me senti mal pra caramba quando ele me agrediu, uma pessoa que eu confiava, de total confiança, de repente, me agredir sem mais sem menos" (1.9) "Eu nunca tinha passado por isso, então foi assim, uma experiência muito traumatizante. Na hora, como era, como foi a primeira vez, então eu fiquei sem saber o que fazer." (12.1)

A agressão acontece repentinamente. A violência física significa a dominação pela força física, quando o homem não encontra outros meios de se impor:

“A minha experiência com o espancamento foi complicado, porque a gente 
tava brigando e de repente ele começou a me espancar... " (10.1)

"Ele me amarrou e me jogou no quintal de casa, e por fim do jeito que ele me amarrou ali, ele me jogou e chamou os parentes dele daqui e como eu não tenho ninguém, quem saiu errada fui eu, porque ele passou para a familia dele que eu quis agredir, ente, e eu falando que não, e eles, como são parentes dele, sai como errada e ele saiu, limpou a casa." (2.2)

A situação de violência instala-se, segundo algumas participantes, após anos de convivência.

“ ...eu tenho uma filha com ele. Ele começou a me espancar eu com a menina no colo. Então, tudo aquilo que você cria num casamento acaba naquele momento, e eu pra vim denunciar." (10.2)

“...para fazer a denúncia, eu acho que foi ainda mais dificil, porque oito anos junto com a pessoa e você não conhecer a pessoa, então fica assim, bem marcante. Chorei, tal, mas consegui fazer." (12.4)

Para outras, a situação de violência persiste desde o início do relacionamento do casal e a violência atinge proporções assustadoras:

"Foi horrivel, eu sempre fui agredida, desde que eu me casei, ai separei. Comecei o relacionamento com ele há 10 anos e há 10 anos sou agredida violentamente mesmo. Agora ainda não, mas antes ele me batia tanto, assim no rosto, e chegava a sair faísca pelo meus olho, eu via estrelinhas, faísca 
mesmo...sumir meus sentidos. Eu já fui quebrada, quebrava minha costela, quebrava meu dedo, chutava, jogava na rua, feito uma cadela, sabe?" (11.1)

Em algumas situações, a agressão acontece devido à separação, por opção da mulher:

“ A gente é casado há 11 anos; moramos juntos há 11 anos, temos um filho. E ver que não dá mais o casamento e ele não aceitar... a gente ter que vir, ele começou a me agredir por isso, ter que vir denunciar, o pai do meu filho por agressão: é uma situação muito dificil, não conseguir resolver só por palavras, é ser muito exposto; expor meus filhos." (9.1)

A agressão envolve outros membros da família, o agressor é instigado pelos seus familiares.

"Ele foi buscar leite na casa da mãe dele, sei lá o que a mãe dele falou pra ele, ele chegou agressivo em casa, falou que eu não ia ir, porque eu tinha outras irmãs, tinha minhas cunhadas, que podia fazer meu serviço. Ai eu disse não João, você deu a palavra pro pai', ai ele disse 'ah! Tudo bem então, só que você vai esperar um pouco'. Daí ele pegou uma filmadora e começou a gravar dizendo que eu tava abandonando a casa, que tava indo morar com outro homem e começou a falar monte de besteira. De repente, sem mais nem menos, ele começou a me agredir, ai comecei a sofrer muito. Foi uma 
experiência que eu espero que ninguém passe pelo o que eu passei. Foi horrivel." (1.10)

A agressão é verbal e física e não acontece apenas no ambiente doméstico:

"Quando meu marido me agredia, ele me agredia na frente dos meus filhos, na rua e ele não me agredia só com força fisica, me agredia psicologicamente. Ele falava na minha cabeça várias e várias horas, eu deixava o meu horário de almoço, perdia o meu serviço com ele falando na minha cabeça. Ele não aceitava a separação, ele não aceitando ele falava, falava. Ele falava e ele via que não tinha como, ele partia para a violência" (9.5)

A humilhação, constrangimento, desespero, raivas, dor e medo são sentimentos que levam a mulher a formalizar a queixa contra o agressor:

"Senti muita raiva quando fiz a queixa, por que a gente é fiel, companheiro, tudo que o companheiro precisa ajuda. De repente, por causa de uma conversa com a mãe dele, ele começou a me agredir, me maltratava, me espancava; uma vez ele falou que ia me matar, tudo, ai eu fiquei, muito chocada mesmo, aí eu vim abrir queixa, pra ver se eu conseguia pegar a guarda do menino, ver se ele me dava sossego." (1.8)

"É uma situação dificil, humilhante, constrangedora, e a gente se sente muito mal e, posso falar mais, desesperadora que leva a fazer isso, entendeu? no 
momento de nervoso de dor, de humilhação, de raiva, de um monte de coisa, a gente é levada a fazer isto dai, prestar queixa, ir na delegacia prestar queixa, é isto dai" (4.1)

"Bom o que me motivou a vir fazer a denúncia é que ele me agrediu muito, na rua mesmo, atrapalhando o meu serviço, e tirou meus filhos da escola, levou lá pra ver eu naquele estado... Então eu via que não tinha mais jeito, que eu tinha que procurar meus direitos" (9.7)

O medo, diante de ameaça à sua vida, leva a mulher a procurar a proteção da lei quando registra sua queixa:

"Bom, de início achei bom prestar queixa por que me senti muito ameaçada"(5.1)

"No momento eu senti humilhada, com medo, pedi uma ajuda, porque ele bebe, ele ameaça matar eu e meus filhos e me botar pra fora de casa. Mas tudo isso dentro da bebida" (6.1)

A agressão não se limita à mulher, atinge também os filhos:

“...ele chegou bêbado, trocou de roupa, pegou a moto, ai perguntei se ia sair, ai ele desceu da moto, veio me espancar, me jogou com a cabeça no trinco do vitrô. que até tá fundo a minha cabeça aqui, ele me jogou na rua com minha filha, tive que dormir fora de casa, e, na segunda-feira vim aqui" (11.4) 
A agressão contra a mulher acontece, também, em situação de separação mal resolvida. Neste caso, a formalização da queixa pode levar à solução da situação de violência.

"Quando ele soube que eu estava namorando, ele amassou meu carro inteiro, e me ameaçou, ameaçou meu namorado, que agora é o atual marido. Eu descobri que tava grávida... ele falou pra mim que aceitaria o meu filho, mesmo não sendo dele, se eu voltasse com ele, e eu não quis, e quando ele ficou sabendo que eu não voltaria com ele, ele passou a me ameaçar mais. Aí ele começou a fazer escândalo no meu local de serviço, ele me parava na rua, eu passava ele me xingava, então ficou insuportável; foi aonde que resolvi prestar queixa dele, que ele ficou sabendo, ele parou de me ameaçar." (5.4)

"Depois como eu não queria continuar com ele, porque eu não queria continuar com uma pessoa, que é meu marido e que me agrediu e que a gente já estava em processo de separação, então eu peguei e fiz a denunciar" (12.3)

Há, na denúncia, a intenção de punição para o agressor, como relata uma participante:

“Eu queria só que ele pagasse pelos erros dele, e que fizessem ele entender que a mulher não é pra ser usada na cama ou em outro lugar, é pra ser respeitada, quero que chamem ele lá e dêem uma lição de moral, que ele precisa levar mesmo. É essa minha verdade, é isso que eu quero que aconteça" (6.4) 
A decisão de denunciar o agressor é conflituosa:

"Bom, minha experiência de ir denunciar foi muito triste, foi muito dificil, por que chegou a um ponto que a gente é casado há 11 anos; moramos juntos, temos um filho. E ver que não dá mais o casamento e ele não aceitar, a gente ter que vir, ele começou a me agredir por isso, ter que vir denunciar, o pai do meu filho por agressão: é uma situação muito dificil, não conseguir resolver só por palavras, ser muito exposto; expor meus filhos" (9.2)

"Então tudo aquilo que você cria num casamento acaba neste momento e eu pra vim denunciar" (10.2)

"E, para fazer a denúncia, eu acho que foi ainda mais dificil, porque oito anos junto com a pessoa e você não conhecer a pessoa, então fica assim, bem marcante. Chorei, tal, mas consegui fazer.” (12.4)

Além do sentido de punição, a queixa formal estabelece um limite para o agressor e reprime a manifestação da violência:

"Porque várias vezes ele me ameaçou e eu nunca fiz nada, mas a partir do momento que ele ficou sabendo que eu prestei queixa ele ficou com medo. E isso pra mim foi bom, me passou uma segurança, porque eu pude confiar na policia e saber que ele iam parar, tanto que ele parou, ele desistiu de me ameaçar; ele me ameaçava muito." (5.2) 
A agressão, em muitas situações relatadas, é conseqüência do uso de bebida alcoólica ou outras drogas ilíciatas:

"É, por que no meu caso, no meu caso que aconteceu isso, meu marido bebe, o defeito dele é a bebida. Ele é uma pessoa trabalhadora, não tem vícios, fora a bebida, ele não, ele não tem assim, envolvimento com outros casos, de assim mulheres, não tem amante. Nós não temos problemas com traição, não é o nosso caso, e ele é uma pessoa que bebe, que fica muito valente quando bebe. Ele se transforma, fica com um comportamento agressivo, pra ele, é aonde ele parte pra ignorância, que ele parte, assim pra agressão, né, fala assim coisas que a gente não deve, entende? Que nem, comigo já aconteceu dois vezes, eu precisava procurar a polícia porque ele tava tão bêbado, tão bêbado, que ele tava assim violento demais e meu medo, sei lá, que ele pegasse alguma faca, porque arma em casa a gente não tem, foi aí que eu fiz a denúncia." (4.4)

"E em questão desta agressão que houve, agora neste final de semana, porque ele só é agressivo quando bebe quando ele não bebe ele é uma outra pessoa, e este final de semana que houve esta agressão. Foi num domingo de Páscoa, ele bebeu domingo todinho..." (11.4)

Para várias mulheres, a agressão faz parte do seu cotidiano, repete-se muitas vezes: 
“A primeira vez que eu apanhei eu fiquei nervosa, com vontade de vir aqui, de me abrir com todo mundo, aqui na Delegacia, assim, mas na hora da raiva eu vim, tudo, conversei. Depois a gente ficou separado, algum tempinho, dai a gente resolveu voltar. Agora na segunda vez que eu tô morando com minha mãe, ele me agrediu de novo e eu senti muita raiva, muito nervosa, resolvi voltar aqui." (7.2)

"Na primeira vez que eu fui foi registrado a ocorrência na Delegacia dos Homens. Aí depois veio a intimação pra ir na Delegacia da Mulher só ele. Ele foi chamado lá, falaram ele mudou, mudou muito, ele ficou uns seis meses que é uma maravilha, mas depois voltou tudo de novo. Agora da última vez ele me ameaçou de novo, e partiu pra cima de mim, ai eu fui na delegacia dar queixa, aí só que eu fui direto na delegacia da mulher. Só que cheguei lá, eu não fui pedir ajuda e eu não me senti assim fortalecida lá também. Ele tava novamente bêbado, aí eu peguei, registrei a queixa lá." (6.3)

“Eu já fiz outras, esta não é a primeira vez que eu fiz denúncia contra ele. Já foi feita outra denúncia, mas não foi levado adiante, não por mim, não sei porquê, não foi levado adiante, porque não recebi intimação." (9.4)

Segue-se, à denúncia, o afastamento do parceiro agressor. O homem, em algumas situações, expulsa a mulher da casa, ou toma atitudes de revanche:

“...tirou tudo de mim, eu só fiquei com o colchão, nem o gás ele deixou pra mim" (2.3) 
“... ele sabia que, se entregasse o mais velho, eu não voltava mais com ele, apesar de gostar muito dele...aí como ele pensou 'seguro o menino, daí uns tempos ela volta de novo'." (1.7)

Após efetivação da denúncia, o parceiro tenta reaproximar-se e retratar-se, buscando a reconciliação. Os filhos, também, influenciam a mulher a rever sua posição:

"O menino meu mais velho tinha ficado com ele, depois ele começou a ir a semana inteira em casa, dizendo que tinha mudado, que não ia acontecer mais, que a situação ia melhorar, entende? Aí foi indo, até que me convenceu, convenceu meu coração voltar." (1.11)

"Foi complicado também, porque eu fiquei naquela dúvida, tem a menina, a gente tinha uma vida junto, eu gosto dele, entendeu? Mas, ahm.. mas eu peguei vim denunciar, mas aí ele começou a pedir uma chance. A minha menina começou a ficar doente também, e, como eu já disse, eu gosto dele. Eu resolvi dar mais uma chance, porque eu acho que todo mundo tem direito a mais uma chance."(10.4)

"A minha experiência foi assim é... foi triste, ficou muito chato o ambiente pelo meu filho também, que ele ficou .. achei que ele ficou mais agressivo, que ele já é um pouco agressivo..." (8.1)

A condição financeira da mulher leva-a a reconsiderar a denúncia, pois não tem autonomia para viver só: 
“...como eu nunca tive pra onde ir, sempre o que ganho é pouco; que eu trabalho como limpeza, meu salário é de 275 reais eu tenho uma filha, o pai não dá pensão, eu não tenho meio de sobrevivência...Eu sei isto não é desculpa pra ficar com ele, se eu estou com ele porque algum sentimento ainda devo ter por ele." (11.3)

"A segunda, achei que deveria retirar, dar mais uma chance pra ele, eu achei que foi assim, uma coisa impensada e porque envolve filhos, 18 anos, envolve um monte de coisas, bens que a gente tem, e no caso a gente ia ter que vender tudo, e eu não tava em condições de tomar partido pra fazer uma divisão de bens, eu doente, me encontrava em tratamento e não tinha pra onde ir, dispor da casa... É uma situação muito complicada, os filhos menores, então eu achei que desta vez passa..." (4.8)

Como a tomada de decisão para realizar a denúncia ao agressor é provocada pela raiva, humilhação e medo no momento da agressão, quando estes sentimentos são amenizados, a mulher re-avalia o próprio comportamento:

\footnotetext{
"Sabe, jả faz quase um mês praticamente desse ato, ele não fez mais nada, e nunca mais e nem dirigiu mais a palavra para mim então está tudo quieto, eu não acho justo também levar adiante uma coisa." (12.6)
}

Algumas participantes defrontam-se com a realidade que é a sua vida: dependem do 
marido e sem ele não conseguem sobreviver. Ou se dão conta de que ainda sentem afeto por ele. Ou avaliam que decidiram denunciar o companheiro sob pressão. Neste momento, quando ele a procura e se retrata, a mulher volta atrás na sua atitude de procurar ajuda externa.

"Ah, eu fiquei, desde criança, gosto muito dele, desde criança, sabe, sou apaixonada, fanática por ele, aí ficando longe dele, do menino, sofri muito, passei muito sofrimento." (1.4)

“...que nós ficamos muito sem saber o que fazia, nervoso um com o outro. Ele não ficou em casa, saiu, ai foi mais pelo meu filho também, aí eu fui retirar a queixa: é que a gente tava se sentindo muito mal com aquilo, porque foi outras pessoas também que pediu pra que a gente fosse... e na hora do nervosismo...depois vem o arrependimento..." (8.6)

“...só que daí teve todas essas coisas de advogado de processar ele. Daí tudo bem, aceitei fazer. Mas quando a gente chega em casa a gente fica mais calma, ai a gente muda a cabaça e decidimos conversar. A gente continuou no mesmo teto, só que afastado, até que a gente resolveu dar mais uma chance, $e$ ele tá passando por psicólogo agora e eu gosto muito dele, mas acho que ele muda, ele pode mudar também?" (7.3)

$\mathrm{Na}$ experiência de duas mulheres, visualiza-se a possibilidade de reconstruir a família longe do agressor. Para outras, voltar com o marido é a única saída. Segundo várias participantes, a desistência é o resultado de uma pressão externa: ou o marido assustado e 
fragilizado com a perspectiva da punição; ou os fatores econômicos que submetem a mulher a esta condição da violência dentro da sua casa; ou um modo de livrar-se do passado e recomeçar a vida readquirindo a tranqüilidade, mas subestimando ou esquecendo as humilhações sofridas.

\section{2 - Relacionamento com as pessoas}

Nesta categoria incluem-se as unidades de significado dos depoimentos que falam das relações interpessoais neste universo da violência doméstica: as mulheres falam das suas relações com as pessoas, no contexto do fato acontecido, da denúncia de agressão à desistência. São as relações com o marido (companheiro), e a as relações com familiares e pessoas envolvidas na situação vivida. Estes conteúdos encontram-se agrupados em subcategorias:

- Relações com o agressor

- Relações com familiares

- Relações com a Delegacia da Mulher

As relações com o marido, neste momento, encontram-se deterioradas. Há sentimentos conflituosos: uma afetividade que levou a aproximação com este homem, com o qual tem filhos, e ao qual ainda se sentem ligadas. Mas este homem que a traiu: ao agredila, torna-se seu inimigo. Uma ameaça:

“Já tinha acontecido outra vez, só que tinha sido diferente, sabe, só que a que 
mais me machucou foi desta vez." (1.10)

"Sabe, eu morei com ele durante cinco anos, durante três anos ele foi bom, dois anos ele começou, não me batia mas me falava coisas horríveis, ofendendo, saia de casa e voltava três ou quatro dias depois, da segunda vez eu não aceitei, e eu acho que a mulher tem que erguer a cabeça porque se o homem pode viver sem a mulher, a mulher também pode viver sem o homem. Ele depende da mulher pra tudo, então eu acho, sei lá, tem muita mulher que falta vergonha na cara e a justiça também tem que ser mais rígida com o homem. É muita coisa que tem que ser acertada." (3.14)

“...então ele bêbado, ele é capaz de matar sim, ele faz qualquer coisa bêbado. Então, eu fico assim, a minha vida corre risco junto com ele e sem ele. De qualquer jeito eu estou correndo risco de vida." (11.12)

Seus depoimentos desvelam várias matrizes desta afetividade - do amor à raiva e à desesperança - até a piedade, quando percebem a fraqueza do agressor. Em várias situações, o agressor arrepende-se e pede nova oportunidade:

“...aí ele começou a ir lá, casa de minha mãe e de meu pai, dizendo que tinha mudado, que tinha se arrependido, que tinha sentido falta de mim, que ele tinha ficado sozinho na casa só ele e o menino pequeno e diz que o menino ficou doente...ô, ele se rebaixou pra mim, aí então me segurei e fiquei lá, fiquei lá, foi indo, até que me convenceu a voltar. Agora até que a gente tá vivendo" (1.11) 
“... e depois eu me senti muito mal, sabe? Eu não conseguia dormir, fiquei muito mal mesmo, muito mal e o filho parecia que cobrava da gente alguma coisa, porque o pai é bom, ele é muito bom. Tem a parte, tem a parte dele que tem muitos problemas, é nervoso, e mais, porque a gente tava se sentindo traída, muito traida... aí depois eu desisti, fui desistir da denúncia. "(8.4) "E foi muito dificil de tá retirando esta denúncia, e perceber que ele está muito arrependido, ele está sofrendo muito com isso e por ele estar muito doente." (9.3)

Após os sentimentos imediatos de raiva pela agressão sofrida, a mulher revê a sua posição na família e avalia a situação em outra perspectiva: vê a fragilidade do companheiro, ou a sua doença:

"Então, eu estou desistindo da denúncia pelo estado de saúde dele, ele está muito doente e eu não quero cobrança dos meus filhos mais tarde. Que, apesar do pai deles me agredir, eles sabem que o pai deles demonstra que gosta muito de mim, que não aceita pelo este amor, que é um amor doentio. "(9.8)

Para algumas, no entanto, as relações com o marido não mudarão: as experiências anteriores mostram um comportamento recorrente:

"Quem nem da outra vez, foi assim, eu não sei qual foi a Delegada que 
chamou ele lá e tudo, quem conversou com ele, mas seja lá quem foi, deixou ele com bastante medo, porque ele tem muito medo de polícia, viu? Seja lá quem foi, botou muito medo nele, sim... mas, ele pode tá ai dando os pulo dele dentro de casa, você falou em chamar a polícia, ele abaixa em dois tempo. Isso é sinal que a bebida dele é o que de conveniência. é de conveniência; isso é que nem muitos outros homens por aí, bebe pra ter coragem de chegar em casa e botar a família pra correr ou judiar da família dentro de casa. Eu penso que é assim, por que os outro vai ser diferente? $O$ álcool acho que faz efeito igual pra todos que bebe ele, viu? Realmente é assim que eu penso que as coisas são." (6.7)

"Mas, tamo indo, tamo levando. Depois que eu tirei o processo ele não me agrediu mais, pelo menos até agora. A gente nem discussão direito não tá tendo, entendeu? e a gente tá tentando seguir o ritmo e levar as coisas. "(10.5) “...e hoje, uma semana atrás, ele voltou pra casa. Me trata, ma dá tratamento melhor, ainda continua nervoso porque ele sempre é, desde que nos casamos."(8.8)

Há situações extremamente conflituosas. O marido violento pode ser essencial à subsistência, e não há como proteger-se de sua violência:

“... porque eu acho que quem não mudou há dez anos, não vai mudar mais, eu acho. Eu sei que vou ser agredida por ele, então é isso aí." (11.8)

“...não pode continuar fazendo isto comigo... eu acho que, que ninguém tem o 
direito de impedir as pessoas de fazerem o que elas querem, o que elas estão sentindo. Eu acho que esta violência por uma decisão minha não está certo, eu tenho a decisão e ter que apanhar por isso?" (9.7)

“...tem as ameaças, porque a gente vem aqui, faz o boletim de ocorrência, mandam chamar ele quando você chega em casa, você é agredida novamente, você torna vir, faz outro, chega, você não tem proteção da policia 24 horas." (11.8)

Ocorre, também, ambigüidade por parte da mulher nesta situação de conflito com o companheiro. A exemplo do que é descrito na fala reproduzida abaixo, na qual a vítima procura relativizar a agressão, para justificar a desistência, mas leva à questão: se foi tão banal a violência, por que houve, num primeiro momento, a denúncia do agressor?

“Ai eu desisti, porque eu não quero prejudicar ninguém, eu acho que se eu mantivesse isso eu estaria prejudicando, por que no fundo, no fundo, eu recuso a crer que ele é uma pessoa tão maldosa e afinal de contas ele só deu um tapa em mim. Se fosse uma coisa grave, tá bem, tá certo que um tapa é um tapa...é uma agressão, que nem eu falei pro juiz, pro delegado; mas é por causa disso, por conta disso, pois foi apenas um tapa e eu quero desculpar, achando o tapa foi acidental, digamos assim." (12.11)

Os familiares aparecem, nos depoimentos das participantes, como parte envolvida na dinâmica da violência, influindo decisivamente na decisão que ela tomará: 
como participantes, sejam os filhos ou os pais, são figuras decisivas na atitude que a mulher assumirá, de denúncia, e, posteriormente, de desistência desta denúncia.

As crianças aparecem, neste cenário, também como vítimas da violência. Há a percepção da mulher de que a sua atitude poderá afetar gravemente a segurança e o bemestar do filho. O sentimento de culpa, já presente ao denunciar, é acrescido pelo sentimento de culpa de privar o filho de um lar estável. Mas também a criança aparece nas descrições das mulheres como recurso de manipulação, por parte do companheiro, para alterar a decisão da mulher:

"Ele tinha ficado sozinho na casa só ele e o menino pequeno e diz que o menino ficou doente... dizendo que não sabia viver mais sem eu, aí foi indo, foi indo até que convenceu o meu coração..." (1.11)

“...porque a gente tem uma criança pequena também e acho que a gente tem que lutar por essa criança também, entendeu? não é só por no mundo e deixar ela lá e começar com briga, pra criança ver também." (10.7)

Diante dos filhos, a mulher teme ser julgada. Privilegia os sentimentos dos filhos pelo pai e aparentemente resolve que se pode esquecer o acontecido e fazer valer as partes saudáveis do relacionamento familiar.

"A minha experiência foi assim é... foi triste, ficou muito chato o ambiente; pelo meu filho também, que ele ficou .. achei que ele ficou mais agressivo, que ele já é um pouco agressivo..." (8.1) 
Porém, em outra perspectiva, a cena de violência presenciada pela criança significa um grave risco para a sua saúde mental:

"Nesse dia que ele me agrediu ele pegou faca, ele amolou as duas facas, veio pra cima de mim, eu tive que correr, sair com a menina de dentro de casa. Então como é que fica a cabeça da minha filha, fica a minha cabeça e a cabeça da minha filha. "(11.13)

Ao pensar nos filhos, a mulher, também, mostra sentimentos conflituosos. Será bom para as crianças mantê-las junto com o pai violento? Ou será muito prejudicial priválas da conveniência do pai? Ou futuramente os filhos a recriminarão por esta decisão? Ou conseguirão sobreviver economicamente se afastados do chefe de família?

Várias participantes, ao serem agredidas, relatam ter recorrido à ajuda de seus familiares ou amigos, que as apoiaram na decisão de denunciar a agressão:

“... daí eu fui morar com a minha mãe, ficar lá com minha mãe e meu pai..."(1.1)

"E também a minha família veio até a casa saber do acontecimento, e eles pedindo que eu fosse .. denunciar: você tá nervosa e... bastante abatida com o que aconteceu, triste e... fui até a delegacia fazer a denúncia." (8.2)

“...eu liguei pros meus pais primeiro eu vim para a delegacia prestar queixa. Outro dia, eu passei pelo IML, constaram manchas no meu corpo porque ele apertava meu pulso fiquei toda machucada. " (2.5) 
... não porque meu pai e minha mãe me maltratava, pelo contrário, me paparicava como se eu fosse, como se eu fosse como um bebezinho, não queria que eu saísse procurar emprego, nada, pois estava me dando, tratando super bem. "(1.5)

"Dai eu fiquei uma semana ficando na casa de amigas, batalhando um emprego. Estou empregada, mas não quero ficar aqui, tô trabalhando no momento, numa escola de informática como vendedora, e passei a me alimentar na casa de amigos, porque ele tirou tudo de mim, de casa. "(2.6) “Eu liguei para a minha família e expliquei toda a situação. "(2.7)

Cria-se, nesta rede de relacionamentos intrincados, uma teia de influências que parecem amplificar os fatos ocorridos e repercutem no comportamento da mulher, quando re-avalia a denúncia que formalizou contra o agressor. Nas situações analisadas no estudo, estes relacionamentos: com os filhos, com os familiares, com os amigos, têm um peso importante na desistência da queixa.

Entre os motivos para a decisão final, dois depoimentos pontuam os extremos nas causas para voltar atrás. Uma participante fala do seu desejo de superar tudo e recomeçar vida nova:

“...achei que. se eu fosse ficar aqui, ele iria ficar me atormentando, porque ele voltou lá pra ex-mulher dele, pra familia dele. Eu tô voltando para minha casa, que este é o motivo de eu retirar a queixa e não ter mais problemas futuramente. "(2.8) 
Essencialmente, ela fala do desejo de retomar a sua autonomia.

No outro extremo, no depoimento mais contundente sobre o quadro de violência doméstica, a participante descreve os motivos pelos quais desiste de sua defesa numa situação de extrema dependência, na qual ela não vislumbra perspectivas para o futuro:

"Eu tenho problema de depressão, estou afastada do serviço por depressão, porque tenho um sobrinho que se matou no trinco da porta, se enforcou. Foi demorado, eu presenciei esta cena, ele foi criado junto comigo, hoje está fazendo dois anos... e tudo isso então... e eu não consigo tomar atitude, eu não consigo me liberar deste choque que eu tive, e eu não consigo me separar dele. Eu não tenho como viver sozinha, eu não tenho ninguém, eu só tenho a menina de 14 anos e eu. E só o que eu ganho que não dá para pagar o aluguel e não dá para sustentar ela, não dá pra nada."(11.12)

Neste contexto, a Delegacia da Mulher aparece como o único apoio. Algumas participantes vêem-na como o local onde conseguirão confirmar seus direitos como pessoa:

“Eu não tenho mais medo dele, mas se fosse pra fazer de novo eu prestaria queixa de novo, e todo mundo que sofre com esse tipo de coisa tem que procurar a delegacia, porque não é certo. "(5.8)

"Eu só acho que se aconteceu alguma coisa, se algumas mulheres sofre 
agressão, eu acho que elas deve denunciar, principalmente se foi mais de uma vez, no meu caso foi uma vez, mas tem muita gente que fica anos nisso então eu acho que deve denunciar sim, porque é um direito elas tem que denunciar, não pode deixar assim não." (10.6)

Outras consideram que ali encontrarão a punição para o agressor e a intimidação para reprimir a sua violência. Há a suposição de que a punição possa atuar de forma educativa, mudando os comportamentos agressivos.

"Na delegacia da mulher, eles vão acreditar na minha palavra, mas não vão poder fazer nada por mim também. Eu falo pra ele: eu também trabalho, chego tarde em casa e, na maioria das vezes, tem semana que ele bebe que nem condenado, tem semana que não. Eu preciso de alguém que fale pra ele o que é o certo é certo o que é o errado..." (6.6)

"Só que na terça-feira ele já veio, nem falou pessoalmente, deixou uma carta, eu tenho a carta, pedindo perdão, pedindo desculpa, que não era justo eu sair da casa que a gente precisava conversar. Ai nós conversamos, jurou, prometeu, que não ia beber mais, aí eu falei que tinha feito boletim de ocorrência, que ele tinha que vir aqui. Tem um boletim desde de outubro que ele não compareceu, foi este boletim que foi arquivado e que vai subir no Fórum 2. Só que, na verdade, aqui na delegacia eu desisti, só que no Fórum eu vou dar este prazo de três meses a ele, pra ver se ele muda realmente."(11.7) 
Outras participantes do estudo relatam experiências anteriores de denúncia contra agressão que não trouxeram resultados: o órgão público parece impotente para a solução do seu problema.

“A própria escrivã, que atende a gente ali, falou que não ia dar em nada, que isso era só um susto, uma queixa, que eles não podiam fazer nada. Ai, daquela hora eu pensei que não adianta nem fazer exame de corpo delito. Vim as outras duas vezes que me chamaram, mas depois na terceira vez eu não vim, ela me ligou, eu falei que não viria, porque a justiça não adianta de nada no Brasil. A justiça de hoje, o homem bate, vem, eles dão um conversadinha; amanhã o homem bate de novo e continua sempre assim e a mulher vai... pra que isso?"(3. 6)

"E também, quando a gente vai fazer a denúncia é uma situação muito humilhante, que nem pra mim que sou mulher que sempre trabalhou fora... minha família não teve essas coisas, ai a gente vai na hora do desespero mesmo e se muito humilhada, de saber que a gente ta lá na delegacia e que ta sendo obrigada a fazer isso, pra ver se a pessoa toma consciência, toma vergonha na cara, para com essa bebida. Ele já fez isso duas vezes, a primeira eu levei o caso até o juiz, foi processado, o juiz falou que se ele fizesse isso de novo ele seria preso, por causa de agredir." (4.7) 
Há incompreensão sobre os procedimentos legais no processo de registrar a queixa:

"Aí, dias depois eles mandaram uma intimação, que eu só vim saber uma semana depois que a delegada ligou pra mim avisando. E a retirada da queixa não foi assim, medo de enfrentar ele lá, esse não foi o medo. Eu penso assim, se o culpado é ele, porque eu tenho que tá junto?" (6.3)

\section{3 - A reflexão sobre a experiência de desistir da denúncia}

Este sub-tema abrange as unidades de significado que expressam a reflexão das participantes a respeito da experiência vivida, na trajetória de denunciar o companheiro e, a seguir, desistir da de dar continuidade ao processo legal. Inclui as convergências:

- Avaliando o significado do acontecido

- A denúncia como tentativa de autonomia

- A ambigüidade ao renunciar

- A tentativa de manter a família

Para várias participantes, a agressão repete-se na vida conjugal. Para algumas, tornou-se habitual. Há a lembrança dos tempos do início do relacionamento, em que havia felicidade. As mulheres lembram-na como que para justificar o casamento.

A principal causa do conflito doméstico que leva à agressão é a bebida. $\mathrm{O}$ marido é bom e trabalhador: quando bebe, transforma-se. A agressão toma várias formas: 
pode ser verbal, mas pode ser extremamente violenta, provocando lesões graves. A mulher, no processo da agressão, sente-se humilhada, desrespeitada, principalmente, por partir de uma pessoa com a qual tem uma relação de afeto e confiança. $\mathrm{O}$ acontecido - agressão, queixa, desistência da queixa - representa uma ruptura na dinâmica do casal.

"Olha, pra mim, falar de minha situação como é que foi no momento de briga, foi, eu me senti, pois eu sou sozinha em Botucatu, vim de cidade de fora, só tinha ele aqui, eu me senti no momento humilhada." (2.1)

“Como foi pra mim, foi sei lá, na hora senti raiva, ódio, pois nem meu pai nunca pôs a mão em mim e é muito duro a pessoa apanhar na cara e falar que ama." (3.1)

“... eu tenho três filhos, não com ele, com o outro, com o primeiro casamento, então, me ameaça assim, se eu vir na justiça, ele, se tirar ele de casa, ele mata minha mãe e meus filhos, e são as coisas que eu tenho na vida, eu não tenho mais anda, então, você fica naquele medo. "(11.11)

“Então por isso que eu tirei o processo, a retirada do processo, mas a mágoa sempre vai ficar, não tem como. Sempre vai ficar essa mágoa e vira e mexe, dependendo do que ele faz, a gente volta a lembrar, isso nunca mais eu vou esquecer, então a gente sempre vai ficar meio com um pé atrás." (10.5)

$\mathrm{Na}$ visão de algumas participantes, há a percepção de viver sob a ameaça constante: a conviç̧ão de que a agressão poderá ocorrer, a qualquer momento, de forma 
definitiva. A raiva e a humilhação levam à denúncia.

Para outras, há a avaliação de que a denúncia, mesmo posteriormente retirada, tem efeito repressor sobre o comportamento de violência. Significa uma arma para defender-se e impor-se diante da agressividade do companheiro:

“ Já ameacei ele, já impus que, se ele chegar a me agredir mais, não vai ter próxima vez, daí eu não vou ter dó mesmo, não volto atrás mais entendeu?"(4.10)

Duas mulheres que se afastaram do agressor falam sobre o efeito positivo da denúncia nas suas vidas:

“... ele ia no serviço do meu marido, agora não vai mais, foi onde ele me deu sossego. Ele me achava bobinha, a partir do momento que eu fiz queixa ele ficou esperto em relação às ameaças que ele fazia. Aí ele parou de me ameaçar... Agora eu tenho sossego, tranqüilidade, eu vou aonde quero e ele não me perturba mais, agora ele me deu sossego. " (5.6)

"Eu acho que teria que ter vergonha na cara e jamais voltar duas e três vezes dar queixa. Porque se ela tá morando ainda com o homem é porque ela aceitou. Tá certo, tem muita gente que não tem custo de vida, não tem como sobreviver, depende do marido, mas eu não tenho estudo, não tenho uma profissão, eu não tenho nada, dependo dos meus pais, minha mãe tá desempregada e meu pai é autônomo eu vivo com as minhas duas filhas, mal 
ou bem eu tô comendo, mas também não tô apanhando, tô tendo uma vida melhor, não adiantava na minha casa eu tinha tudo o que eu queria, mas não tinha sossego, a qualquer momento eu podia tá dormindo, tinha que dormir com o olho aberto, e outro fechado, porque ele podia chegar drogado e me bater, pra que essa vida?" (3.12)

Para ambas, mesmo retirando a denúncia, a formalização da queixa deu-lhes tranqüilidade. Porém, o efeito mais importante desta atitude foi levar à decisão de romper o relacionamento.

As mulheres que continuam com os companheiros, após este processo de “denúncia - desistência da denúncia", valorizam os sentimentos de afeto que os unem e a lembrança de que ele pode ser uma pessoa decente e confiável. A solidariedade e o companheirismo levam ao sentimento de piedade pelos seus comportamentos. Há como que um arrependimento - culpa, provavelmente - por terem ousado comparecer a uma Delegacia formalizando acusação contra o marido.

"Pensar bastante, que às vezes nem dá mesmo pra gente pensar porque na hora do nervosismo você não tá sabendo o que tá fazendo; e outra... procurar algum conselho melhor, assim, uma pessoa que te aconselhe o que você deve fazer ou não."(8.9)

Há fortes motivos para manter as relações familiares, apesar da ameaça: 
“... a falta do menino e a falta de casa, que na minha casa eu fazia tudo o que eu queria, eu senti assim livre na minha casa, aí eu senti muita falta da minha casa e do meu filho, ai que eu voltei pra trás."(1.6)

Uma das participantes, que rompeu o relacionamento após a agressão, interpreta os motivos que levam uma mulher a continuar ao lado de quem a maltrata:

"Eu acho também, que não tenho nada contra nem com a vida de ninguém, se a mulher resolve continuar com o marido depois de apanhar, é porque ela gosta, e daí eu acho que nem a justiça tem que entrar mais no meio." (3.9)

Há perspectivas diversas nas avaliações que as mulheres que participaram do estudo fazem da sua experiência de denunciar e desistir da denúncia ao agressor. Se para algumas desistir é provocado por sentimentos de afeto pelo marido e pelos filhos, ou pela insegurança econômica e o medo de novas ameaças; para outras, ao denunciar mostraram a sua força, mesmo desistindo no meio do processo. Este é o caso das duas mulheres que abandonaram o agressor. Aquelas que continuam na sua companhia, expressam a esperança de que a denúncia, mesmo que depois anulada pela desistência, terá um papel punitivo ou reformador do seu comportamento.

Recorre-se à proteção legal por acreditar na denúncia como instrumento de defesa e punição; aquelas que tiveram experiências de reincidência de agressão mostram-se descrentes da efetividade do recurso legal.

Um aspecto relevante desvelado pelos dados do estudo refere-se à análise que 
as participantes fazem a respeito de si mesmas como pessoa e das suas possibilidades de autonomia, neste processo conflituoso em que ora lutam para defender-se, ora desacreditam da legitimidade do seu direito de defesa. 


\section{Discussão}

I-Denúncia e Desistência

Ao descrever a agressão física e moral que lhe aconteceu, levando-a a denunciar o companheiro, a mulher expõe a sua condição humilhante dentro da família: num espaço supostamente seguro, na convivência de pessoas com as quais compartilha a intimidade, a mulher se sente agredida, não só fisicamente, mas na sua confiança, abalando suas crenças no casamento e na família. Como que ocorrem, além do ato violento momentâneo, rupturas nesta estrutura tradicional. Porém, este ato momentâneo não se restringe ao momento do conflito e da agressão: é uma violência que persiste, repete-se e repercute na dinâmica do casal, envolvendo os filhos. As mulheres expõem, nos seus relatos, os sentimentos ambíguos entre: de um lado, a afetividade pelo agressor e o desejo de acreditar no compromisso assumido entre ambos; de outro lado, a percepção do companheiro que se transforma em inimigo. Esta ambigüidade gera conflitos e sentimentos contraditórios. Adeodato et al. (2005) descrevem o perfil da mulher agredida pelo parceiro: as mulheres reagem à agressão, verbal ou fisicamente (64\%), mas também mentem sobre o acontecido (26\%), sentem culpa (16\%) ou refugiam-se no alcoolismo (6\%). Buscam ajuda em igrejas, centros de apoio e cuidados médicos.

Entre esta população de mulheres, 50\% dizem sofrer agressão diariamente e $54 \%$ utilizam medicamentos ansiolíticos. Em pesquisa sobre a violência contra a mulher em São Paulo, capital, Schraiber et al. (2002) descrevem que $80 \%$ dos agressores eram os maridos ou ex-companheiros. Em estudo realizado no Rio de Janeiro, 69,4\% das agressões 
sofridas por mulheres foram cometidas por parceiros e ex-parceiros. No estudo de Schraiber et al. (2002), a agressão pelo parceiro é freqüente, severa e repetitiva. Neste estudo, 33\% das participantes relataram conhecer mulheres que viviam situações de violência doméstica por parte dos parceiros.

Puccia (2004), em pesquisa realizada em Santo André (SP), conclui que as estimativas de prevalência de violência por parceiros íntimos sugerem alta magnitude do fenômeno, entre usuárias dos serviços públicos de saúde da região. Esta violência, à semelhança de dados dos estudos citados anteriormente, repete-se para $58 \%$ das participantes, tendendo a ser severas para $23 \%$ delas.

Algumas participantes do presente estudo, desvelando a sua ambigüidade, descrevem a agressão como uma demonstração de fragilidade, quando o homem não encontra outros recursos para impor a sua força. A agressão é verbal e física e acontece muitas vezes na presença dos filhos. Há situações em que o agressor associa-se aos seus próprios familiares na agressão, o conflito ampliando-se e atingindo a família originária, e às vezes, $\mathrm{o}$ ambiente de trabalho.

Os motivos para formalizar a denúncia contra o companheiro são apresentados nos depoimentos: a raiva e a humilhação, ou o medo pela ameaça à sua vida. Algumas mencionam o envolvimento dos filhos na agressão, sentindo-se obrigadas a protegê-los.

Duas participantes consideram que efetivar a denúncia reprime a violência do agressor. Uma delas continua com o companheiro e espera que a intervenção policial o transforme, embora tenha desistido da denúncia, no decorrer do processo.

Por que a desistência?

Não foram localizados estudos a respeito desta questão entre a bibliografia 
consultada. Para as participantes desta pesquisa vários fatores levam-nas a rever a sua decisão de denunciar o agressor: o arrependimento do parceiro e as suas tentativas de conciliação; ou a dependência financeira, que obriga a mulher a preservar o relacionamento. Há, também, os sentimentos de afeto pelo parceiro, e a necessidade de manter a família devido à existência dos filhos. Um dado surpreendente emerge dos depoimentos: a mulher coloca em segundo plano a sua auto-estima e respeito, quando percebe a fragilidade masculina sob a atitude violenta. Por vezes a justifica, ao descrever um homem que precisa recorrer às drogas, ou que está doente, ou que é "nervoso". Como que revertendo a condição do agressor para a condição de "vítima".

Padovani e Willians (2002), em estudo de caso sobre o companheiro agressor, analisaram um homem que tende a minimizar a agressão e negar o próprio comportamento, culpando a vítima pelo ocorrido. Esta interpretação masculina encontra respaldo nas concepções tradicionais sobre a família, que discriminam a mulher e colocaram-na em condição inferiorizada na relação com o marido (Saffioti, 1997). Adeodato et al. (2005) descreveram um agressor que ingere álcool (70\%) e outras drogas; que é violento com outras pessoas $(58 \%)$, inclusive com os filhos. Entre os motivos da agressão, além do uso de drogas, o ciúme e a suspeita de traição da mulher, e, em menor freqüência, do companheiro.

Apresenta-se, no presente estudo, um grupo de mulheres que reagem à agressão, num primeiro momento, em defesa própria ou de revide ao agressor, utilizando a arma disponível: denunciá-lo ao Poder Legal. Neste grupo, encontram-se mulheres que já fizeram esta trajetória mais de uma vez, algumas relatando que houve bons resultados imediatos. Porém, ao "voltarem à realidade", provavelmente sob a pressão externa dos 
familiares, do marido, dos filhos - ou mesmo tomar consciência de que estará desprotegida sem o marido - ela volta atrás e retoma a sua posição de mulher dentro da família tradicional. A trajetória da denúncia à desistência pode ser compreendida percebendo-se a sua realidade existencial, como ela a vive: ela percebe, após a tentativa de avançar na sua autonomia, que a mesma não se encontra ao seu alcance. Continuar o processo de denúncia do agressor, na sua percepção, talvez seja mais complexa e difícil, talvez inviável, em relação à realidade de violência que é a sua realidade. E que tende a continuar assim.

Estes dados apresentam similaridades com aqueles dos estudos citados nesta análise: prevalece a lógica da dinâmica familiar tradicional. Prevalece o perfil de uma mulher com baixa auto-estima e dependente, e de um marido (companheiro) que tem os privilégios masculinos e privilégios de dono da casa.

Mesmo uma participante, que sofreu agressão e perseguição por parte de um homem do qual se afastou, não sendo mais dependente dele e afastada do risco de represálias, esta desistiu da denúncia, alegando desejar seguir em frente e esquecer o ocorrido.

A denúncia tendo reprimido o comportamento violento do ex-companheiro, ela preferiu, simplesmente, desistir do processo legal contra ele e esquecer a agressão sofrida. 
II - Relações com o marido, a família, a DDM.

De acordo com Cabral (1999), os trabalhos sobre a violência doméstica contra a mulher não avaliaram a relação conflituosa entre o agressor e a vítima, no espaço familiar, quando se sabe que a mulher não é apenas a vítima neste contexto, mas um dos participantes no conflito. Este autor descreve a mulher que sofreu violência: apresenta sintomas depressivos e ansiosos, perturbação do sono, transtornos alimentares, fobias, disfunções sexuais, manifestações psicossomáticas, alcoolismo e a base de calmantes.

O agressor, o outro participante da dinâmica da violência, é descrito pelas participantes do presente estudo apresentando comportamento violento, quando não consegue impor sua vontade. Alguns tornam-se agressivos quando alcoolizados, outros mostram descontrole emocional constante. Algumas participantes justificam estes comportamentos, alegando suposta fragilidade emocional ou a condição de doente. Há como que a necessidade de justificar o comportamento agressivo do companheiro. Pode-se pensar, à semelhança dos dados apresentados por estudo de Adeodato et al. (2005), que a mulher sente culpa ao reagir, ou apresenta baixa auto-estima.

Os valores familiares tradicionais são reafirmados pelas mulheres quando trazem para os seus depoimentos a atuação dos familiares, seus ou do companheiro, interferindo na situação - e são estes valores que condicionam a mulher a tentar recompor as relações familiares, através da desistência da denúncia, voltando à sua condição de mulher nestas relações. Manter a queixa pode significar a ruptura familiar, ou danos para a família ao atingir a figura do seu chefe.

Em função disto, a relação com o companheiro precisa ser recomposta, mesmo 
porque, para algumas, a denúncia teria apenas o objetivo de disciplinar o marido agressor e mostrar-lhe que externamente existem forças para reprimir o exagero da sua dominação. Uma participante diz textualmente: “...quero que chamem ele lá e dêem uma lição de moral que ele precisa levar mesmo". Esta é uma mulher que já teve experiência de violência anterior, minimizada temporariamente pelo registro da queixa.

Esta mulher reproduz e quer manter, como está, a relação conjugal. Talvez ela não consiga visualizar a possibilidade de outras formas de relacionamento com o companheiro, no qual a mulher preserve sua autonomia e perceba-se como igual ao homem, em direitos e deveres.

Quando recorre aos seus direitos legais, algumas participantes aparentemente não compreendem, ou não foram informadas efetivamente, do papel da Delegacia da Mulher como apoio na situação de violência doméstica. Algumas participantes apresentam a sua compreensão sobre as finalidades de efetivar a denúncia contra o agressor: reprimi-lo e castigá-lo. Uma delas retirou a queixa por que foi intimada, juntamente com o marido, para comparecer à delegacia. Considerou-se isenta de responsabilidade, entendendo que a intimação consistia numa punição, e ela não a merecia. Não há a perspectiva de que além da punição ao agressor, a Delegacia teria a possibilidade de exercer o papel educativo efetivamente: ajudar a ambos no sentido de refletirem e discutirem os seus problemas conjugais, mediados por um profissional que estimularia a superação dos conflitos domésticos.

As noções de justiça e igualdade entre marido e mulher não aparecem claramente nos depoimentos. Porém, as mulheres evocam o seu direito a ser respeitada, e reconhecem que são dominadas e humilhadas. A partir desta percepção, talvez se possa 
pensar em estimular as vítimas de violência doméstica a se posicionarem na busca dos seus direitos. Schraiber et al. (2002) afirmam que poucas mulheres nesta condição reconhecem a situação de agressão doméstica vivenciada como violência, mostrando que ocorre a relativização da violência à qual foi submetida. Ou talvez considere esta violência no âmbito familiar como parte da sua vida.

Estes questionamentos remetem a reflexão sobre o que significou para a mulher, vítima de agressão do companheiro, viver a experiência e fazer a denúncia e, a seguir, desistir da mesma. Como pode ser interpretada esta trajetória de defender-se legitimamente, avançando na busca de sua autonomia, e retornar, à seguir, a condição de vítima passiva da violência?

III - A reflexão sobre o vivido

Segundo Minayo e Souza (1998), a violência só pode ser compreendida no contexto sócio-econômico, político e cultural, revelando o caráter das estruturas de denominação (de classes, grupos, etnias, faixas etárias, e gênero). A violência surge como expressão de conflitos entre aqueles que querem manter os privilégios de dominação e aqueles que se rebelam contra a opressão.

Nesta perspectiva, a violência doméstica que atinge a mulher pode ser interpretada nas suas contradições: a estrutura familiar tradicional, que propõe a união de duas pessoas; ao mesmo tempo diferenciando os papéis que desempenharão neste contrato, ao atribuir ao chefe-de-família o poder das decisões, e à mulher, a contrapartida da 
submissão a estas decisões. A agressão do companheiro contra a mulher pode ser compreendida como a reafirmação do domínio do homem nas situações do conflito conjugal. A mulher reage, tenta defender-se e termina por ajustar-se à situação, se desejar mantê-la.

Os dados deste estudo desvelaram a postura da mulher que denuncia a agressão e desistiu a seguir, em duas situações diversas: 1) a situação na qual a mulher é agredida, registra queixa contra a agressão, afasta-se do agressor e, ainda assim, retira a sua queixa; 2) e a outra situação, na qual a mulher é agredida, registra a queixa, continua ao lado do agressor e retira a queixa - compreendendo-se, nesta condição, que, ao continuar junto ao marido, avalia ser inviável manter um litígio legal contra ele, o que impossibilitaria manter a relação familiar.

Se, na segunda situação, a motivação da renúncia ao processo legal contra o companheiro justifica-se pela intenção de preservar a relação; na primeira situação, quando ocorre a separação do casal, aparentemente há uma contradição entre a desistência da denúncia e o afastamento do agressor. Neste caso, a mulher teria autonomia para manter a punição legal contra o seu agressor, afirmando os seus direitos, pois não se encontraria em condição de submissão ao ex-companheiro.

É possível interpretar que, no conflito doméstico, qualquer que seja a solução, perdura a lógica tradicional: a definição dos papéis conjugais, ou seja, a mulher submissa à autoridade masculina. Esta família, que a mulher deixou para trás, depois de ter sido agredida pelo companheiro, e que deseja esquecer - por isso pretendendo apagar o acontecido com a desistência da denúncia - possivelmente tenderá a reproduzir-se na estrutura familiar futura (possíveis relacionamentos futuros da mulher), pois ela não 
conseguiu efetivamente solucionar o conflito anterior. Não conseguiu assumir seu papel de igualdade em relação ao homem. A desistência do processo contra o agressor só pode ser compreendida nesta concepção da reprodução da estrutura familiar tradicional: talvez a mulher não consiga assumir a sua autonomia como pessoa pois, para ela, esta autonomia não está ao seu alcance. Não apenas pelos motivos de dependência financeira, mas porque ela se percebe como a parte frágil na relação com o homem: a ela cabe compreender este homem agressor, que é doente, que sofre, que é "bom" essencialmente - é o companheiro que ela escolheu, com o qual se comprometeu, também, nos momentos difíceis. À mulher, no contrato familiar, cabe compreender e perdoar. Não são estas características femininas ressaltadas em verso e prosa? Naturalmente, por escritores e poetas masculinos. Talvez esta estrutura, que coloca a mulher como parte frágil na relação conjugal, baseie-se nesta 'fragilidade' como ponto crucial para manter a estrutura familiar como ela é concebida tradicionalmente: na lógica das relações de poder, há que haver a figura do líder dominante, e há que haver o correspondente na relação de poder: o dominado. Por mais que as mulheres tenham conquistado direitos, a família, como é compreendida, ainda é percebida neste contexto de dominação, inclusive e principalmente, pelas mulheres. Nos depoimentos das participantes deste estudo, percebe-se que, mesmo as mulheres que trabalham e têm certa autonomia financeira, podendo reivindicar, numa separação, apoio financeiro do marido para a manutenção dos filhos - estas mulheres ainda se vêem presas à relação conjugal.

Nesta perspectiva, sobra pouco espaço para a reflexão sobre as possibilidades de um relacionamento igualitário do casal: a visão do casamento (formal ou informal) como um espaço de compartilhar direitos e deveres, tarefas e papéis numa perspectiva justa. Esta 
postura, que se opõe à percepção da família patriarcal, na minha percepção de pesquisadora, escapa, também, das orientações e providências legais da Delegacia da Mulher. No depoimento de uma participante, a intimação da mulher para comparecer diante do delegado, junto com o marido, foi compreendida pela mulher como punição a ela, quando, na sua visão, apenas o agressor deveria ser punido. Não lhe foi explicitado (ou talvez ela tenha compreendido), que o objetivo dessa intimação ao casal pudesse resultar em tentativas de superar o conflito do casal, talvez os encaminhando para assistência especializada, na busca de equilibrar o relacionamento conflituoso. Os dados de estudos, citados no decorrer desta análise, descrevem a vítima de violência doméstica e o seu agressor como pessoas que apresentam sinais de baixo auto-estima, depressão e envolvimento com o uso de alcoolismo e drogas ilegais. Compreendendo a agressão conjugal - que provavelmente, também, acontece trocando-se a posição do agressor: a mulher sendo a agressora e o homem a vítima - pode se pensar na família vítima de uma violência social, que ocorre nas situações, da sociedade como um todo, nas situações do trabalho e etc. Situações nas quais o homem, também como vitima da violência social, vive a agressão das estruturas de dominação na figura do poder econômico e político. Minayo e Souza (1998) citam: "vários estudiosos da atualidade observam que se torna cada vez mais necessária uma epidemiologia da violência inclusive uma epidemiologia dos problemas psiquiátricos gerados por ele".

Estudos anteriores citados (Adeodato et al., 2005; Cabral e Bancaleoni, 2000; Padovani e Willian, 2002) remetem às relações entre a violência doméstica e os sintomas psicopatológicos dos participantes desta violência, considerando a necessidade de programas específicos para assistência a essas patologias, que são tanto a causa como o 
efeito das situações de agressão que acontecem na família.

A violência freqüente, que permeia os relacionamentos no âmbito sócioeconômico e político e reproduz-se no âmbito familiar, passa a ser encarada, nas suas formas menos visíveis, como "natural" pelas mulheres agredidas pelos companheiros. Schraiber et al. (2002), ao analisar a violência contra a mulher, avaliam que poucas mulheres vivendo situações de agressão, dentro e fora de casa, percebem tais situações como "violência". Mesmo quando esta violência se expressa em agressões muito severas. Estas observações remetem à necessidade de se pensar na reforma dos sistemas educacionais: na minha compreensão, a percepção dos direitos humanos desenvolve-se no decorrer do desenvolvimento da criança e do adolescente, a partir da percepção de si mesmo, como pessoa de direitos e deveres, que podem ser sintetizados nos conceitos de igualdade, justiça e autonomia para todos, indistintamente. As mulheres apenas superarão a sua visão de inferioridade em relação ao homem quando se perceberem, a si mesmas, como portadoras naturais de igualdade como pessoa. Além da luta por direitos iguais, a sua autoestima e respeito próprio é que legitimarão a sua reivindicação de igualdade.

Relatos de experiências descrevendo o apoio a mulheres vítimas de agressão mostram a possibilidade de conscientização e reeducação da mulher, no sentido de conquistar os seus direitos à cidadania (Moreira, 1999; Alves e Coure Filho, 2001). Os estudos desses autores sugerem a necessidade de maior integração entre as instituições públicas que assistem esta mulher e a necessidade de capacitação dos recursos humanos envolvidos na reconstrução da percepção da mulher sobre si mesma, como pessoa de direitos e deveres.

Confirmando esta perspectiva, resultados de estudo de Angulo-Tuesta (1997), 
em pesquisa sobre a violência doméstica desenvolvida com profissionais de saúde inseridos em dois modelos de atenção de nível primário na cidade do Rio de Janeiro e em Niterói, mostram a violência contra a mulher como um problema histórico e enraizado na sociedade baseada em um sistema que aceita a superioridade do homem; a subordinação da mulher; a dominação e o poder do homem sobre as decisões e a vida da mulher. Neste contexto, a autora enfatiza a importância da independência econômica das mulheres como um elemento possível de transformações na relação homem-mulher, a fim de que elas consigam posições de igualdade e liberdade perante o homem. Para tanto, a educação e o acesso a serviços sociais seriam questões fundamentais para possibilitar uma participação integral na sociedade. Diante da constatação de que as mulheres se calam sobre a violência, por medo e vergonha, a autora conclui sobre a importância dos profissionais de saúde, ao atenderem essa mulher, desempenharem um papel que apóie e estimule a sua expressão sobre a violência, um primeiro passo para que ela se insira efetivamente como cidadã de direitos.

Analisando as falas das participantes deste estudo, é possível compreender que, embora expressando-se sobre a situação vivida individualmente, elas visualizam estas dimensões ocultas da violência que sofrem: ao assumir a ambigüidade em denunciar e desistir, mas identificando-se como dependentes do companheiro, afetiva e/ou economicamente, e percebendo-se presas nesta rede familiar e social, que as limita e impede de ir adiante. Porém, mesmo reconhecendo-se assim limitadas, mostram a consciência de que se negam à autonomia, contraditórias na desistência dos seus direitos mais essenciais.

Ao ouvir a experiência dessas mulheres, vítimas do companheiro violento, que 
escolhem desistir da denúncia, a pesquisa - no contexto de um tempo e espaço delimitados - buscou descrever e compreender os significados existenciais da violência, na perspectiva dessas mulheres, na realidade familiar e social que vivenciam. O objetivo do estudo foi acrescentar, aos inúmeros estudos sobre este tema extremamente complexo, estes dados qualitativos que permitem uma visão aprofundada da realidade vivida, interpretada por pessoas que falam da sua própria realidade. $\mathrm{Na}$ minha compreensão, como pesquisadora que se aproximou desta realidade, dialogando com as participantes, penso ter atingido este objetivo. Não apresentando estatísticas ou explicações causais para o fenômeno complexo da violência doméstica, não pretendendo generalizar os dados encontrados - não é este o objetivo da pesquisa fenomenológica. Mas sim compreendendo a perspectiva individual, peculiar de cada uma dessas mulheres, desvelando o fenômeno "desistir da denúncia contra o companheiro agressor" contextualizado na sua existênćia e na facticidade à qual foram lançadas, dando voz aos significados que conscientemente atribuem à violência vivida, na convivência com seu companheiro. Ao trazer estes resultados para o conhecimento já existente na literatura, penso que se acrescentam subsídios para a melhor compreensão da mulher que sofre violência doméstica, aprimorando os programas de atendimento à sua saúde. 


\section{NOVOS HORIZONTES DESVELADOS PELO ESTUDO, NA PESPECTIVA DA PESQUISADORA}

A minha inquietação em relação a este tema iniciou-se durante a coleta de dados na DDM, para a minha dissertação de Mestrado, quando, levantando os crimes cometidos contra a mulher através dos Boletins de Ocorrência, inquietava-me o registro de arquivamento dos mesmos. As justificativas para o arquivamento baseavam-se, em geral, no fato de que a mulher voltara a viver harmoniosamente com o marido ou companheiro. Esta atitude das mulheres agredidas indignava-me, não considerava aceitável que a mulher maltratada fisicamente apagasse esta violência como se nada tivesse acontecido.

O local que me fora cedido para levantar esses dado, na DDM, devido às paredes desprovidas de isolamento ao som, permitia a escuta involuntária dos pedidos das mulheres que ali compareciam para solicitar arquivamento das denúncias contra os seus agressores. Somava-se a isto a minha impressão de revolta ao constatar a dor no rosto das mulheres, quando registravam a queixa de agressão. A inquietação inicial a este respeito, ampliada por esta convivência com as mulheres agredidas, resultou na definição pelo projeto de pesquisa do doutorado: investigar a experiência das vítimas que desistiram da denúncia do agressor.

Iniciei a coleta dos depoimentos nesta expectativa: aproximar-me das experiências destas mulheres em busca de compreender os significados da sua atitude de desistir dos seus direitos de cidadã. Foram ouvidos doze depoimentos, sendo que quatro mulheres foram entrevistadas dentro de suas residências e oito mulheres entrevistadas numa sala reservada dentro da Delegacia. 
Nas entrevistas na Delegacia, tive o cuidado de preservar a privacidade das participantes: procurei por uma sala mais isolada, onde não haveria a possibilidade de outras pessoas ouvirem o depoimento. Outro cuidado foi agendar as entrevistas desvinculadas de qualquer procedimento na Delegacia. A participante era esclarecida sobre o trabalho de pesquisa, insistindo que se tratav de uma atividade sem nenhuma interferência ou ligação com a DDM. Além destes detalhamentos, explicitava os direitos ao sigilo e anonimato da sua participação, antes que concordasse com a entrevista e assinasse o termo de consentimento esclarecido. Avalio, agora, que os depoimentos ali coletados, aparentemente, não tiveram interferência ou qualquer barreira, devido ao ambiente em que se desenvolveram. No entanto, considero que os depoimentos coletados nas residências das participantes apresentaram alguns aspectos que favoreceram tanto a espontaneidade da expressão das participantes como me permitiram compreender melhor o universo dessas mulheres. Ouvi-las na sua casa contribuiu decisivamente no meu processo de transformação em relação ao modo como encarava a postura de desistência destas mulheres.

Uma delas residia em casa emprestada por um amigo. A casa localiza-se em região bem periférica, uma das mais carentes de recursos do município. Tanto ela como o marido, o seu agressor não trabalhavam. O boletim de ocorrência registra, no item 'profissão do marido': desocupado. Isto significa, segundo a polícia, que se trata de pessoa que não tem ocupação e que nunca trabalhou. Vivem de favores. Tanto ela, como o marido e os filhos recebem ajuda da Prefeitura, dos familiares e amigos. Em seu relato diz que, após ser agredida, foi morar com os pais, onde era bem tratada, mas preferiu retornar ao lar por causa dos filhos e por se sentir melhor em sua casa, seu "cantinho", mesmo que seja tão precário. 
Outra situação que me marcou foi a de outra entrevistada: após a agressão, recebeu apoio dos familiares e, influenciada por um deles, que é advogado, num impulso de momento, por revolta e indignação, foi à delegacia registrar o boletim de ocorrência. Após denunciar, desaprovada pelo filho, sentiu-se mal por tê-lo feito. Relata que só melhorou o relacionamento com o filho quando retirou a queixa. Durante a fala, expressou seu desespero por ter sido influenciada a denunciar, o que não era a sua intenção. Arquivar o processo significou para ela o alívio, pela normalização do relacionamento familiar, principalmente com o filho, que sofria por ela ter denunciado o seu pai.

Outro relato fez-me refletir sobre a minha postura inicial de indignação contra a decisão destas mulheres: a situação descrita por uma participante, que se encontra na segunda união, de 10 anos, conflituosa e cheia de violência desde o início. Essa mulher vem de um primeiro casamento semelhante, com os mesmos episódios de violência física e moral. Ela trabalha e tem uma filha do primeiro casamento, que presenciava as agressões do pai e atualmente presencia as do padrasto contra a sua mãe. A referência de relacionamento familiar para essa mulher, assim como para a sua filha, é de violência. Desistiu de continuar com o processo criminal por não ter para onde ir e como se sustentar e à filha. Durante o relato, pôs-se a chorar, o que me levou a encerrar a entrevista. Após isso, ficamos conversando um tempo para que a mesma pudesse se recompor antes de ir embora da delegacia. Conseguimos colocá-la num programa de apoio psicológico.

Apesar de não estar claro no depoimento de outra participante (os dados que apresento a seguir constam dos dados oficiais sobre o agressor), ela vive uma situação de violência em que o marido - que tem uma profissão respeitada e admirada pela sociedade tornou-se violento após constatação de que é portador de uma neoplasia. Foi agredida 
várias vezes, recorrendo por duas vezes à DDM, mas, mesmo assim, decidiu por continuar com o marido para ajudá-lo na fase difícil e não se contrapor ao filho. Desistindo, então, de dar prosseguimento à denúncia do agressor. Posteriormente, fui informada, pelos policiais da DDM, que a mesma retornou à delegacia para registrar um nova ocorrência e que, então, separou-se do marido.

Outras mulheres entrevistadas permaneceram com os maridos por não quererem abandonar o que construíram juntos e por não terem para onde ir. Em várias situações, a violência só acontece quando há ingestão de álcool por parte deles, o que, na visão das vítimas, aparece como uma prova de que o companheiro não seria, no momento da agressão, responsável pelo que fazia.

Uma outra desistiu da denúncia, por querer continuar uma relação de amizade por causa das filhas, mesmo não estando juntos, pois o casamento já estava deteriorado quando da agressão e a separação já ocorrera. Essa mulher tem uma profissão e um emprego estável.

Cada uma apresenta os seus motivos para desistirem do seus direitos: na verdade, descrevem a situação que vivem e o intrincado relacionamento familiar, no qual a violência sofrida perde, em todas as situações descritas, a posição de prioridade que, na minha perspectiva ao iniciar este estudo, deveria ocupar. Na minha perspectiva inicial, defender-se da agressão é um direito básico, e é um dever quando a pessoa se respeita como tal, em qualquer que seja o contexto da violência. Na perspectiva dessas mulheres, que abriram mão deste direito, os seus depoimentos desvelam que há as questões existenciais que antecedem este 'ver-se' como pessoa de direitos: para elas, a prioridade sempre são os filhos e a relação afetiva, aparentemente, jamais arriscariam este valor essencial. Poder-se-á 
dizer que esta constatação reafirma os dados da literatura sobre a concepção tradicionalista da família, em que a mulher assume a submissão ao status quo. Na minha concepção atual, interpretando as suas falas, elas reagem, cada qual, à sua maneira, respondendo às necessidades do momento que elas identificam, sempre afetivamente. Mesmo quando afastada e separada do agressor, a lembrança da afetividade e a esperança de reconstituir uma família fazem-na relevar a agressão sofrida e a negá-la, pois é isto que fazem quando desistem da denúncia e de buscar pela punição do agressor. Porque ela ainda precisa crer que é possível re-fazer a sua família 'ideal', mesmo que seja com outro parceiro. Mas, nesta contradição, talvez percam a perspectiva de que, não resolvendo bem o conflito anterior, o reproduzirão, provavelmente, na próxima relação.

Para mim, como pesquisadora deste tema que me inquietava, esta trajetória de compreender a perspectiva das mulheres agredidas que desistem da denúncia levou-me também, ao envolvimento com a sua assistência legal. Ao freqüentar a DDM, acabei por envolver-me com os profissionais da lei e a visualizar melhor a sua atuação.

A cada denúncia, o profissional da lei, representado pelos escrivães e delegada, significa para essas mulheres uma busca de proteção, de recuperar a sua dignidade e a sua autonomia. A cada relato, percebia um pedido de ajuda, o que me deixava angustiada, por não saber o que fazer, apenas me dispondo s a ouvi-las. Após os primeiros depoimentos, já não mais as via como coitadas, que sofrem agressões porque querem. Durante esse período, ocorreu o atentado terrorista "11 de setembro", e após isso, a mídia expôs, exaustivamente, a cultura dos paises muçulmanos, onde há muita violação dos direitos da mulheres. Estes fatos reforçaram a realidade da agressão contra as mulheres como um fenômeno que transcende fronteiras e é atemporal. 
À medida que prosseguia no meu trabalho e nas leituras, minha inquietação se transformva em angústia: como eu, enfermeira, posso ajudá-las, dentro de uma instituição como a Delegacia de Defesa da Mulher de Botucatu. Tornei-me amiga da Delegada e dos escrivães e investigadores da Polícia Civil que durante este percurso sempre se prontificaram a me ajudar e o fizeram-no sempre. Conversava muito, durante a espera de depoimentos, com a Delegada a respeito de viabilizar uma ajuda de fato e de concreto a essas mulheres que procuravam a DDM. Comecei a freqüentar grupos e Fóruns de Debates com mulheres, deste e de outros municípios, onde uma das pautas era sobre Violência Doméstica. A parceria com a Delegada foi muito importante, pois ela me informava destas reuniões e me apresentava a mulheres que participam de grupos que querem modificar esta situação. Um psicólogo da região iniciou um trabalho voluntário dentro da DDM . Começamos a pensar em um grupo de apoio. Iniciei visitas domiciliares, em casos de denúncias que são feitas para a DDM elucidar a sua autenticidade. Numa reunião, conheci uma terapeuta ocupacional que faz um trabalho voluntário com a Polícia Militar e trabalha com a agressividade dos integrantes dessa corporação: ela se propõe a acompanhar o agressor e a família vitima de violência que procuram a DDM, em conjunto com a Delegada e escrivões. Fui convidada a participar do grupo. O pessoal da DDM, inicialmente, fará a triagem das pessoas que se interessarem em participar e num final de semana mensalmente iremos abordar temas solicitados pelos mesmos. Os policiais que atendem a DDM são unânimes e solidários ao afirmarem que o homem agressor, também, precisa e quer ajuda para extinguir a violência em suas casas. Botucatu é um dos primeiros Municípios a realizar um Protocolo de Atendimento 'a mulher vítima de violência Sexual, atuando conjuntamente o Hospital das Clínicas da FMB_Unesp, Polícia Civil, na figura da 
DDM e Polícia Militar do Estado de São Paulo. Estamos iniciando uma luta para que este município tenha um Abrigo para a Mulher em risco de Vida e estamos endossando a luta para alteração da pena da Violência Doméstica ( $§ 9^{\circ}$ do artigo 129 do Código Penal), tendo em vista que, apesar da criação do crime específico de Violência Doméstica, o legislador não enquadrou a conduta do agressor, visando a aplicação de uma pena superior a um ano, portanto o crime de violência doméstica, cuja pena de detenção é de seis meses a um ano deverá obrigatoriamente, ser julgado pelos Juizados Especiais Criminais (Lei 9099/05) que julgam crimes de menor potencial ofensivo.

O julgamento da Violência Doméstica na lei 9099/05 é considerado pelos operadores de direito um retrocesso, porque não podem prender o agressor, dificultando com isso seu efetivo combate e prevenção.

Este caminho percorrido como que foi movido pelas duas pesquisas que desenvolvi sobre o tema, a do Mestrado e esta do Doutorado. Agrada-me avaliar que os dois trabalhos, também, estimularam toda a atividade que temos desenvolvido em parceria na DDM, com descrevo no parágrafo anterior. Mas sobretudo avalio a minha própria evolução a respeito da compreensão dessas mulheres que desistiram das denúncias que são as protagonistas deste trabalho: uma ajuda consistente por parte dos profissionais da assistência jurídica e da assistência à sua saúde pode fazer a diferença no seu caminhar para compreender-se e visualizar-se como pessoa que tem direito à justiça e à igualdade dentro da sua casa. Porém é necessário associar a este esforço localizado a luta democrática para alcançar a justiça social como um todo, o Estado garantindo que todos os cidadãos tenham acesso aos direitos humanos básicos: sobrevivência digna, educação, trabalho e oportunidades de escolhas. 


\section{REFERÊNCIAS*}

Adeodato VG, Carvalho RR, Siqueira VR, Souza FGM. Qualidade de vida e depressão em mulheres vítimas de seus parceiros. Rev Saúde Pública. 2005; 39(1):108-13.

Alves AM, Coure-Filho P. Avaliação das ações de atenção às mulheres sob violência no espaço familiar atendidas no Centro de Apoio à Mulher (Belo Horizonte) entre 1996 e 1998. Ciênc Saúde Coletiva. 2001; 6(1): 243-57.

Angulo-Tuesta AJ. Gênero e violência no âmbito doméstico: a perspectiva dos profissionais de saúde [Mestrado]. Rio de Janeiro: Fundação Oswaldo Cruz, Escola Nacional de Saúde Pública; 1997.

Ariès P. História social da criança e da família. $2^{\mathrm{a}}$ ed. Rio de Janeiro: Guanabara Koogan;1981.

Azevedo MA. Mulheres espancadas: a violência denunciada. São Paulo: Cortez; 1986.

Badinter E. Um amor conquistado: o mito do amor materno. $6^{\text {a }}$ ed. Rio de Janeiro: Nova Fronteira; 1985.

Bassuk EI, Dawson R, Perloff J, Weinreb I. Post-traumatic stress disorder in extremely por women: implications for health care clinicians. J Am Med Womens Assoc. 2001; 56 (2): 7985.

Brasil. Ministério da Justiça. Conferência Mundial sobre Direitos Humanos (Viena - 1993).

\footnotetext{
* International Committee of Medical Journal Editors. Uniform Requeriments for Manuscripts Submitted to Biomedical Journal: sample references. [homepage on the Internet]. Bethesda: U.S. National Library of Medicine; 2003[las updated 2003 July 09; cited 2005 Jun 01]. Available from: http://www.nlm.nih.gov/bsd/uniform requeriments.html National Libray of Medicine. List of Journals indexed in Index Medicus. Washington, 2003. 240p.
} 
Direitos da mulher são direitos humanos. Brasília: Imprensa Nacional; 1994.

Cabral MAA, Banceleone PG. Representações da violência conjugal de 117 mulheres de Campinas - Brasil. J Bras Psiquiatr. 2000; 49(8):277-85.

Cabral MAA. Prevenção da violência conjugal contra a mulher. Ciênc Saúde Coletiva, 1999; 4(1): 183-91.

Day VP, Telles LEB, Zoratto PH, Azambuja MRF, Machado DA, Silveira MB, et al. Domestic violence and its manifestations. Rev Psiquiatr. 2003; 25 supl 1: 9-21.

Falcão D. Mulher resiste em denunciar parceiro. Folha de São Paulo. 1999 Nov. 22; cad. 4:6.

Heise L. Gender-based abuse: the global epidemic. Cad Saúde Pública. 1994; 10 suppl:135-45

Jong LC. Perfil epidemiológico da violência doméstica contra a mulher em cidade do interior paulista [dissertação]. São Paulo: Faculdade de Saúde Pública, Universidade de São Paulo; 2000.

Kikwood C. Leaving abusive partners; from the scars of survival to the wisdom for change London: Sage Publications; 1993

Kronbauer JFD, Stela Nazareth Meneghel SN. Perfil da violência de gênero perpetrada por companheiro. Rev Saúde Pública. 2005; 39(5):695-701.

Martins J, Bicudo MAV. A pesquisa qualitativa em psicologia. Fundamentos e recursos básicos. São Paulo: Moraes; 1989.

Martins, J. Um enfoque fenomenológico do currículo: educação como poíesis. São Paulo: Cortez; 1992. 
McCauley J, Kern DE, Kolodner K, Derogatis IR, Bass EB. Relation of low-severity violence to women's health. J Gen Intern Med. 1998; 13(10):687-91.

Merleau Ponty, M. Phénoménologie de la Perception. Paris: Gallimard; 1945.

Minayo MCS, Souza ER. Violência e saúde como um campo interdisciplinar e de ação coletiva. Hist Ciênc Saúde - Manguinhos. 1997/1998; 4(3):513-31.

Moreira V. Grupo de encontro com mulheres vítimas de violência intrafamiliar. Estud Psicol. $1999 ; 4(1): 61-7$.

Muto E. Álcool está ligado a 52\% dos casos de violência doméstica. J Paulista. 2003;16(179).

Nucci GS. Código penal: comentado. $4^{\mathrm{a}}$ ed. rev atual ampl. São Paulo: Editora Revista dos Tribunais; 2003.

Padovani RC, Willians LCA. Intervenção psicoterapêutica com agressor conjugal: um estudo de caso. Psicol Estud. 2002; 7(2):13-7.

Plichta SB, Duncan MM, Plichta I. Spouse abuse, patient-physician communication, and patient satisfaction. Am J Prev Med. 1996; 12(5):297-303.

Puccia MIR. Violência por parceiros íntimos de usuárias dos serviços de atenção primária à Saúde em Santo André- SP [dissertação]. São Paulo: Faculdade de Saúde Pública, Universidade de São Paulo; 2004.

Sadala MLA, Adorno RC. Phenomenology as a method to investigate the experience lived: a perspective from Husserl and Merleau Ponty's thought. J Adv Nurs. 2002; 37(3):282-93.

Saffioti HJB. Violência doméstica ou a lógica do galinheiro? In: Kupstas M, (organizador). 
Violência em debate. São Paulo: Editora Moderna; 1997. p.39-57.

Saffioti HJB. Violência contra mulher: agressão, vitimização e padrões culturais. In: Seminário Nacional Violência contra a Mulher; 1994. São Paulo.

Schraiber LB, d'Oliveira AF, França-Júnior I, Pinho AA. Violência contra a mulher: estudo em uma unidade de atenção primária à saúde. Rev Saúde Pública. 2002; 36(4): 470-7.

Schraiber LB, d'Oliveira AFLP. Violência contra mulheres: interface com a saúde. Interface Comunic, Saúde, Educ. 1999; 3(5):15-26.

Senado Federal. Secretaria Especial de Comunicação Social. Subsecretaria de Pesquisa e Opinião Pública. Relatório de Pesquisa SEPO 03/2005: violência doméstica contra a mulher. Brasília; 2005.

Silva IV. Violência contra mulheres: a experiência de usuárias de um serviço de urgência e emergência de Salvador, Bahia, Brasil. Cad Saúde Pública. 2003; 19 supl 2:263-72.

Silva MV. Violência contra a mulher: Quem mete a colher? São Paulo: Cortez; 1985.

Soares LE, Soares BM, Carneiro LP. Violência contra a mulher: as DEAMs e os pactos domésticos. In: Violência e política no Rio de Janeiro. Rio de Janeiro: Ed. Relume Dumará/ISER; 1996. p.65-106

Woolhouse S, Brown JB, Lent B. Women marginalized by poverty and violence. Can Fam Physician. 2004; 50:1388-94. 


\section{unesp \\ UNIVERSIDADE ESTADUAL PAULISTA \\ CAMPUS DE BOTUCATU}

FACULDADE DE MEDICINA

COMITÈ DE ÉTICA EM PESQUISA

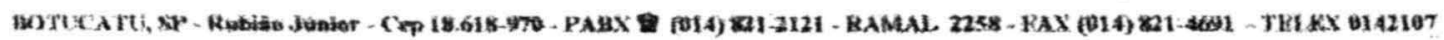

otucatu, 04 de junho de 2.001

OF. 192/2001-CEP

MVCR/asc

'rezada Senhora,

De ordem da Senhora Presidente deste CEP, informo que o Projeto e Pesquisa intitulado "Desistindo da denúncia: relato de mulheres vítimas le violência domestica", recebeu do relator parecer favorável, aprovado em euniäo de 04 de junho de 2.001

O CEP, no entanto, sugere a pesquisadora que acrescente ao ermo de Consentimento Livre e Esclarecido, qual será o destino das fitas ravadas após a defesa do Doutoramento.

Sendo só para o momento, aproveito o ensejo para renovar os rotestos de elevada estima e distinta consideração.



ustrissima Senhora

rof Lin Chau Yong

epartamento de Enfermagem

aculdade de Medicina de Botucatu 


\section{ANEXO II \\ Termo de Consentimento Livre e Esclarecido para Participação em Trabalho Científico \\ PROJETO DE PESQUISA}
"Desistindo da Denúncia ao Agressor: Relato de Mulheres Vítimas da Violência Doméstica"

O objetivo da presente pesquisa é o de estudar os motivos que levaram a mulher vítima de violência doméstica a desistirem de levar adiante o procedimento policial.

As informações deverão ser obtidas mediante consulta a documentos da Delegacia de Defesa da Mulher de Botucatu e entrevistas com as mulheres vítimas de violência doméstica, a partir do ano de 2003, que registraram boletins de ocorrência e termos circunstanciados no e que desistiram de levar adiante o processo contra o agressor.

Tendo sido satisfatoriamente informado sobre o projeto de pesquisa "Denunciando o agressor: relato de mulheres vítimas de violência doméstica" sob a responsabilidade da Prof ${ }^{a}$ Lin Chau Jong do Departamento de Enfermagem da FMB - UNESP, de doutoranda do Departamento de Saúde Materno-Infantil da Faculdade de Saúde Pública da USP, orientada pela Prof ${ }^{a}$ Dra. Ana Cristina D'andretta Tanaka, declaro que concordo em participar da mesma.

Estou ciente de que as informações serão utilizadas exclusivamente pela pesquisadora, que a mesma está disponível para responder a quaisquer perguntas e que poderei retirar esse consentimento a qualquer tempo. Esclarecimentos adicionais poderão ser obtidos com a pesquisadora pelos telefones: (014) 3811-6070, 3811-6004 ou 38135264.

de 2004.

$$
\text { Prof }^{\mathrm{a}} \text {. Lin Chau Jong - Pesquisadora }
$$

Rua Miguel Di Credo, 1022 - Jd. Panorama

Botucatu/SP - CEP 18608-008

e-mail: ljong@fmb.unesp.br

Tel.: (14) 3811-6070 